\title{
WestVirginiaUniversity
}

THE RESEARCH REPOSITORY @ WVU

Graduate Theses, Dissertations, and Problem Reports

2017

\section{Three Essays on the Economic Impacts of Immigration}

Juan T. Sayago-Gomez

Follow this and additional works at: https://researchrepository.wvu.edu/etd

\section{Recommended Citation}

Sayago-Gomez, Juan T., "Three Essays on the Economic Impacts of Immigration" (2017). Graduate Theses, Dissertations, and Problem Reports. 6574.

https://researchrepository.wvu.edu/etd/6574

This Dissertation is protected by copyright and/or related rights. It has been brought to you by the The Research Repository @ WVU with permission from the rights-holder(s). You are free to use this Dissertation in any way that is permitted by the copyright and related rights legislation that applies to your use. For other uses you must obtain permission from the rights-holder(s) directly, unless additional rights are indicated by a Creative Commons license in the record and/ or on the work itself. This Dissertation has been accepted for inclusion in WVU Graduate Theses, Dissertations, and Problem Reports collection by an authorized administrator of The Research Repository @ WVU.

For more information, please contact researchrepository@mail.wvu.edu. 


\title{
Three Essays on the Economic Impacts of Immigration
}

\author{
Juan T. Sayago-Gómez \\ Dissertation submitted to the \\ College of Business and Economics \\ at West Virginia University \\ in partial fulfillment of the requirements \\ for the degree of \\ Doctor of Philosophy \\ in \\ Economics \\ Randall W. Jackson, Ph.D. \\ Joshua C. Hall, Ph.D. \\ Mark Burkey, Ph.D. \\ Peter V. Schaeffer, Ph.D. \\ Adam D. Nowak, Ph.D. \\ Brian J. Cushing, Ph.D., Chair \\ Department of Economics \\ Morgantown, West Virginia \\ 2017
}

Keywords: Migration, Crime, Undocumented immigration, Poverty, Spatial econometrics

Copyright 2017 Juan T. Sayago-Gómez 


\section{Abstract \\ Three Essays on the Economic Impacts of Immigration \\ Juan T. Sayago-Gómez}

The movement of population is a part of the adjustment process in economics and society to changes in conditions and the environment. However migration can affect the host country and have negative consequences, such as poverty, crime, and overcrowding the social systems that provide access to health care and public goods. This dissertation addresses some cases of what are the consequences of migration: First it considers the opening of the European Union to new countries in 2004 and 2007 insignificant effects from the increase of all immigrants, African immigrants, and Latin American immigrants on crime rates of the regions, but there is a positive correlation from the immigration of Europeans on property crime. Then it addresses the choice of undocumented immigrants to locate in the United States. The results from this analysis shows the importance of economic variables and highlight an interesting condition related to the population size in sanctuary cities in comparison to the existence of sanctuary cities and the number of sanctuary cities. The third study analyzes the effect of exogenous migration shocks on the measurements of poverty in Colombia. I find that poverty measurements are sensitive to the migration shock. Also the policies created from such measurements have a bias because the poverty measures were affected by the internal conflict in Colombia. 


\section{Acknowledgements}

I have always had a curiosity for "why" and "how" things happen. The path that my curiosity laid out for me determined my reading selections and enabled me to develop strategies to critically analyze the information I had just read. My curiosity has also increased my interest in expanding my knowledge by reading and learning about a broad range of subjects, widening my areas of my interests. My Ph.D. in Economics has enabled me to solve some of these questions and encourages me to continue this journey. I would like to take this opportunity to thank the people who have been influential to my academic development over the last six years.

I would like to thank Drs. Luis Lorente, Gustavo Junca, and Silvia Figini at Universidad Nacional de Colombia and Università Degli Studi di Pavia; they showed me that research serves a purpose and that understanding the tools of economics is vital to using them correctly. Their example has motivated me to attain a Ph.D. in Economics. I would like to thank my friend Gianfranco Piras who was also responsible for my application to West Virginia University. He taught me $\mathrm{R}$ and spatial econometrics even before I joined West Virginia University and for that I am forever grateful.

The next person I would like to thank is Dr. Brian Cushing, the person who sent my acceptance letter to the Ph.D. program and who patiently stood by my side during my slow development. He has helped me improve in numerous ways. His teachings have had an enormous impact on my views of determining what is important and techniques for defining priorities. His comments and stories provided me a framework for to see things in a different perspective. I would also thank him for all the conversations and advice through these years; I am grateful for all that he has done for me.

Dr. Randall Jackson was my supervisor for most of my journey. Additionally, he was my committee member and played an important role in my education and development. Dr Jackson's wise advice gave me the direction I needed to grow as an academic and gently nudged me toward meaningful and important lessons. I always 
enjoyed dropping by his office to share with him my new research ideas. Without fail, he would provide insightful comments and questions. Finally, I owe him a great debt of gratitude for his never-ending patience and support.

My other dissertation committee members, Dr. Joshua Hall, Dr. Adam Nowak, Dr. Peter Schaeffer, Dr. Donald Lacombe, and Dr. Mark Burkey all played an important role in my education and in this dissertation. I appreciate all of your efforts to teach me and help me to grow. An additional thank you to Dr. Adam Nowak, who worked with me on various projects and guided my approach to them. Adam taught me great things in econometrics, $\mathrm{R}$, and research; I regret that my understanding of the concepts took longer than I would have liked.

I would like to say thank you to my "family" at the Regional Research Institute (RRI). The RRI received me with open arms, space and friendly professors, fellow students, and helpful staff. The professors gave us interesting assignments, allowed us to contribute to research projects, and freely gave us research advice. The students also provided advice for solving problems, and the staff, Caigan and Doris, would proofread my drafts, and guided me through university procedures. Their help was always appreciated. I am also grateful to the RRI and the Department of Economics for their generous support for travel to academic conferences over the years. I was able to get feedback and meet colleagues who influenced my work.

I would also like to thank my fellow students at West Virginia University, especially Christa Court, Masha Sorokina, Jennifer Moreale, Zheng Tian, Mark Middleton, Michael Court, Andrew Tackett, and Yulia Chikish for the help they provided me both in and outside the classroom, on this dissertation, but more importantly for their friendship.

Finally, I would like to express gratitude to my family. Their continual trust and support drove me to always finish my tasks. My Mom and Dad taught me to work hard and to follow my dreams. I am eternally grateful for the examples they set for me and the guidance they provided. I want to give my heart-felt thanks to the unsung heroine in this journey-my beautiful wife Johanna who has inspired me by the unwavering belief she has in me and by her examples of persistence regardless of the bumps and road blocks along the way. She understands that these are lessons from which I can learn. She has sacrificed much and has been my rock during some difficult times and with a gentle hand she has propelled me forward.

Who I have become is thanks to all of you and to many more people; I hope I have 
made you proud of the academic I have become. 


\section{Contents}

Acknowledgements $\quad$ iii

List of Figures $\quad$ vii

List of Tables viii

1 Introduction $\quad 1$

1.1 The economics of immigration . . . . . . . . . . . . . . . 1

1.2 Crime and migration $\ldots \ldots \ldots \ldots \ldots \ldots$

1.3 Choice of undocumented immigrants . . . . . . . . . . . . . . 2

1.4 Displacement and poverty . . . . . . . . . . . . . . . . 3

2 Crime and Migration: The Case of the European Union Enlargements of 2004 and $2007 \quad 5$

2.1 Theoretical and empirical literature . . . . . . . . . . . . . . . . 9

2.2 Estimation methodology . . . . . . . . . . . . . . . . . . 13

2.3 Data description . . . . . . . . . . . . . . . . . . 18

2.3.1 Dependent variables . . . . . . . . . . . . . . . . . 18

2.3.2 Independent variables . . . . . . . . . . . . . . . . . . . . . 19

2.4 Results. . . . . . . . . . . . . . . . . . 20

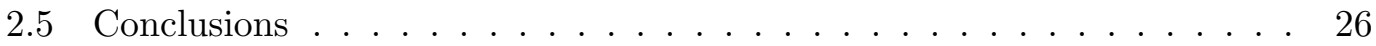

3 Determinants of Undocumented Immigrants' Choice to Locate in United States $\quad 31$

3.1 Migration theory . . . . . . . . . . . . . . . . . 33

3.2 Data description . . . . . . . . . . . . . . . 37

3.3 Estimation strategy . . . . . . . . . . . . . . . . . . 40

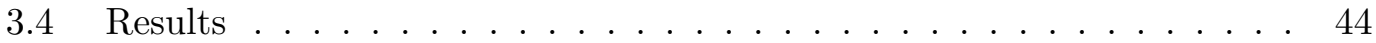

3.5 Conclusions . . . . . . . . . . . . . . . . . . . . 49

4 Changes in Poverty Measurements and Forced Migration: The Case of Colombia $\quad 51$

4.1 Background literature . . . . . . . . . . . . . . 54

4.2 Data description . . . . . . . . . . . . . . . . . 57

4.2.1 Dependent variables . . . . . . . . . . . . . . . . . . 59

4.2 .2 Independent variables . . . . . . . . . . . . . . . 64 
4.3 An application of Shift-Share analysis to poverty . . . . . . . . . 70

4.3.1 Shift-Share decompositions . . . . . . . . . . . . . 70

4.3.2 Data requirement for the Shift-Share analysis to poverty . . . . . 72

4.3.3 Results of the Shift-Share analysis . . . . . . . . . . . . 73

4.4 Empirical strategy . . . . . . . . . . . . . . . . . . . 74

4.5 Results from immigration and poverty . . . . . . . . . . . . . 78

4.6 Policy implications and conclusions . . . . . . . . . . . . . . . 91

5 Conclusions $\quad \mathbf{9 4}$

5.1 Conclusions . . . . . . . . . . . . . . . . . . . . 94

5.2 Future research $\ldots \ldots \ldots \ldots \ldots$ 


\section{List of Figures}

2.1 Timeline of the European Union Enlargements. Source: Delbecq and Waldorf (2010) and European Union (2013) . . . . . . . . . . . 7

2.2 Total Foreign Born Population by Country. Source: European Union

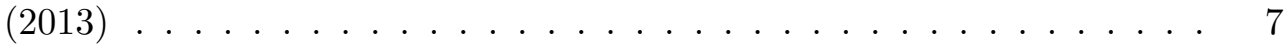

2.3 Crime Counts and Foreign Population in Italy. Source: Italian National Institute of Statistics (ISTAT) . . . . . . . . . . . . . 8

2.4 Crime Counts and Foreign Population in Spain. Source: the Department of State of Spain, and the National Institute of Statistics of Spain (INE) 7 8

3.1 Share of undocumented immigrants in 2010. Source: Warren and Warren

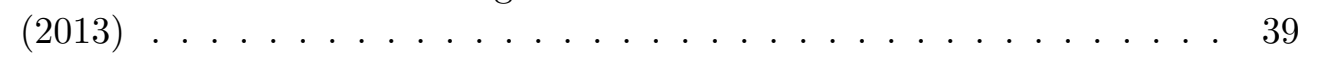

4.1 Poverty measured by Unsatistied Basic Needs (UBN) . . . . . . . . . . . 62

4.2 Poverty measured by Multidimensional Poverty Index (MPI) . . . . . . 67

4.3 Change in the UBN in the municipalities . . . . . . . . . . . . . . . 68

4.4 Forced Displacement . . . . . . . . . . . . . . . 69

4.5 Shift in trend growth rate of non-poor population in the Municipalities . 93 


\section{List of Tables}

2.1 GDP per capita in European Countries. Source: EUROSTAT. . . . . . 20

2.2 Descriptive Statistics. . . . . . . . . . . . . . . . . . 21

2.3 Testing procedures to the Panel models. . . . . . . . . . . . . . . 21

2.4 Panel Model Results for Total Crimes. Results in parenthesis are the standard errors. . . . . . . . . . . . . . . . 23

2.5 Testing procedures to the Panel models . . . . . . . . . . . . . . 24

2.6 Panel Model Results for Property Crimes. Results in parenthesis are the standard errors. . . . . . . . . . . . . . . . 25

2.7 Testing procedures to the Panel models . . . . . . . . . . . . . 26

2.8 Panel Model Results for Violent Crimes. Results in parenthesis are the standard errors. . . . . . . . . . . . . . . . 27

2.9 Panel Model Results for All types of Crimes using European immigrants. All results use the random effects model. Results in parenthesis are the standard errors. . . . . . . . . . . . . . . . . . . .

2.10 Panel Model Results for All types of Crimes for Latin immigrants. All results use the random effects model. Results in parenthesis are the standard errors. . . . . . . . . . . . . . . . . .

2.11 Panel Model Results for All types of Crimes for African immigrants. All results use the random effects model. Results in parenthesis are the standard errors. . . . . . . . . . . . . . . . . .

3.1 Descriptive statistics. . . . . . . . . . . . . . . . . . . 39

3.2 Likelihood Ratio (LR) Test for the spatial panel models. . . . . . . . . . 45

3.3 Lagrange Multiplier Tests (LM) for the specification of the spatial panel models. . . . . . . . . . . . . . . . . . 46

3.4 Hausman Test for the spatial panel models. . . . . . . . . . . . . . . . . 46

3.5 Results for the spatial autoregressive panel models with fixed effects of the Share of undocumented immigrants of all population. The values in parenthesis are t-statistics. . . . . . . . . . . . . . . 48

3.6 Effect estimates for the spatial panel models with fixed effects of the Share of undocumented immigrants of all population. . . . . . . . . 50

4.1 Brief descriptions of dependent variables and main independent variables. 58

4.2 Descriptive Statistics . . . . . . . . . . . . . . . . . 59 
4.3 Percentage of population with Unmet Basic Needs Total and by Component. Author's Calculation . . . . . . . . . . . . . . . 61

4.4 Multidimensional Poverty Index by dimensions and variables. Source: Angulo et al. (2013) . . . . . . . . . . . . . . . . . . 64

4.5 Shift-Share decomposition of poverty - National regional Component change . . . . . . . . . . . . . . . . . 73

4.6 Lagrange Multiplier Test for Total Poverty Regressions . . . . . . . . . . 79

4.7 Lagrange Multiplier Test for Housing Characteristics Poverty Regressions 79

4.8 Lagrange Multiplier Test for Access to Utilities Poverty Regressions . . 80

4.9 Lagrange Multiplier Test for Housing Conditions Poverty Regressions . 80

4.10 Lagrange Multiplier Test for the Access to Education Poverty Regressions 80

4.11 Lagrange Multiplier Test for Economic Capacity Poverty Regressions . . 80

4.12 Lagrange Multiplier Test for Total Poverty Regressions from MPI . . . . 81

4.13 Spatial Regression Results for Total Poverty Measured by UBN. . . . . 82

4.14 Regression Results for Housing Characteristics Poverty Measured by UBN. ............................. 83

4.15 Regression Results for Access to Utilities Poverty Measured by UBN. $\quad 85$

4.16 Regression Results for Housing Conditions Poverty Measured by UBN. 86

4.17 Regression Results for the Access to Education Poverty Measured by UBN. . . . . . . . . . . . . . . . . . 87

4.18 Regression Results for the Economic Capacity Poverty Measured by UBN. . . . . . . . . . . . . . . . . . . . 89

4.19 Regression Results for the Total Poverty Measured by MPI. . . . . . . 90 


\section{Chapter 1}

\section{Introduction}

\subsection{The economics of immigration}

Studies of migration have focused on the causes and destination choices of the population that moved (Ravenstein, 1885, 1889). The work by Ravenstein (1885) and Ravenstein (1889) focused on understanding what were the amenities and desired features in the destination place by most migrants and what population would move from one place to another. The study of migration in developing countries increased after the seminal work of Harris and Todaro (1970). Their paper created an analytical framework that allowed migration to be explained as differences in economic variables between regions affect the decisions.

This dissertation focuses on the consequences on migration within and from developing countries on destinations. Most of the migrants follow a rationality similar to the ideas of Harris and Todaro (1970) and the different changes affect their prospective migratory behavior. This dissertation will consider the possible consequences of migration on economically related issues, such as crime, undocumented migration, and poverty. 


\subsection{Crime and migration}

The relationship between migration and crime has recently been on the center stages of political discussions. Supporters of the relationship use them to justify the travel bans and other initiatives to restrict the arrival of immigrants. The European Union (EU) included new countries in 2004 and 2007 and all the new countries are less developed than the original EU countries. This enlargement allowed migrants to move freely from these new member countries to the traditional EU members.

Chapter 2 examines the relationship between migration and crime. We focus on the increased flow of immigrants into the EU countries due to the enlargement of the EU in 2004 and 2007. It allowed "restricted" immigration from newer members to the original EU 15 countries. This change in immigration policy provides us with an experimental case for studying the effect of increased migration on crime. We focus the analysis on total criminal activities, violent crimes, and property crimes, and highlight possible effects on crimes related to a monetary gain. Property crimes increase when unemployment of low skilled workers increases because these unemployed people could be involved in criminal activities. We analyze the NUTS 2 regions of Italy and Spain from 2003 to 2008, using data from the Eurostat, European national statistical centers and institutes, and National Police or Ministry of Interior reports. We control for socioeconomic factors related to crime and apply an instrument to control for migration-crime endogeneity. The coefficients associated with the share of immigrant population are not significant for all crimes, violent crime, and property crimes.

\subsection{Choice of undocumented immigrants}

The decision of where to migrate and live by undocumented immigrants has important policy implications because the local labor market receives a group of workers that arrive at a location and will take jobs. Chapter 3 analyzes what factors affect the 
migration process and what the determinants are in choosing the destination place. I set up three spatial panel models to analyze the effects from economic variables, as well as demographic and social characteristics. These variables can push or pull illegal workers to locate in a specific state of the United States. To explore what factors are related to the decision of undocumented immigrants, I build a spatial panel model of the percentage of undocumented population by state for the years from 2005 to 2010 . In the panel, I include economic variables that can attract undocumented workers, such as real wages and real GDP per capita, since previous studies on migration state that migrants will move to locations where they can get a higher income or expect one, and these theories should also affect undocumented immigrants. I use variables for social networks and sense of safety, such as the status and size of sanctuary cities. The size of the sanctuary cities is relevant due to the possibility of blending in. Labor market theories are also important to explaining the choices of undocumented immigrants because the incentives affect low skill employment throughout the country.

\subsection{Displacement and poverty}

Chapter 4 explores the relationship between internal displacement and changes in poverty measurements; more specifically how the displaced population affects the measures of poverty by Unsatisfied Basic Needs (UBN) in Colombia for the period from 1993 to 2005. To examine this relationship, first I apply a Shift-Share Decomposition Analysis to the changes in poverty measurements in Colombian municipalities. This analysis splits regional change to reduce poverty into three components: national, regional, and sectoral. These components suggest which municipalities really decreased their non-poor population and compares it with the national trends. This analysis also highlights that municipalities decreased poverty, but did not increase the number of non-poor population. Also, displaced population left these municipalities. The municipalities to which they moved increased the non-poor population, thus also affecting the changes in the poverty rate. I explore the hypothesis that the outcome of the UBN 
measure of poverty is affected by forced migration. I estimate a spatial econometric model to measure the effect of the displacement of population on the change in poverty. The model reveals that a large group of rural municipalities reduced poverty through the displacement of population by the armed groups in Colombia's conflict. I develop an alternative model using the newly developed measure called the Multidimensional Poverty Index (MPI) as the dependent variable. I conclude that forced displacement did not affect the outcome of the measurement of poverty using the MPI in Colombian municipalities. 


\section{Chapter 2}

\section{Crime and Migration: The Case of the European Union Enlargements of 2004 and 2007}

The relationship between immigration and crime has been a policy discussion in many countries. It has helped to determine the rigidity of immigration requirements, including the level of security checks required before allowing immigrants to enter the countries. This chapter examines whether or not increased immigration to Italy and Spain due to the 2004 and 2007 European Union (EU) enlargements resulted in increased crime.

These enlargements provide an interesting case study because they open borders into the EU region (see Figure 2.1) to countries from the center and east of Europe. The enlargement granted the citizens from the new member countries the right to move freely, choosing where to live and work within the EU (Delbecq and Waldorf, 2010). On average, the population from the new member countries has lower socio-economic conditions and lower income, compared with other EU countries. Since income is one of the main attractors for migration (Harris and Todaro, 1970; Sjaastad, 1962; Greenwood, 1993; Lucas, 1993), an inflow of migrants from the new member countries to 
the rest of the EU was expected to occur. These changed migration patterns have changed labor markets, affecting labor market access as a whole, as well as the kinds of jobs available (Delbecq and Waldorf, 2010; Giulietti et al., 2013; Kahanec et al., 2013). Italy and Spain were selected as the focus for three main reasons: First, they have data available and published online for the period of analysis; second, these two countries are among the top five immigrant destinations; and third, these countries did not modify their NUTS 2 during the period under study.

The new countries in the two recent EU enlargements (Figure 2.1) increased the foreign population that could access the labor market in the previous countries (see Figure 2.2). This means that low-skilled natives would face greater competition. Additionally, new migrants who could not find work would have to return to their countries or resort to illegal activities. The EU15 countries $^{1}$ set up some restrictions that were intended to limit the migration, but, according to previous research, those restrictions "had a very weak effect" (Delbecq and Waldorf, 2010). The size of the immigrant population in Italy and Spain increased from 1.9 million to 4.5 million. The number of immigrants increased in both countries from 2003 to 2008. For the same period the number of crimes increased in Italy at least through 2007. In Spain, the pattern was highly variable (see Figures 2.3 and 2.4).

Previous work addressing the relationship between crime and migration has found mixed evidence. Some papers found a positive and significant correlation between crime and migration (Spenkuch, 2014; Borjas et al., 2006; Bianchi et al., 2012), while others have not found significant relationships (Butcher and Piehl, 1998; Le Brun, 2008; Moehling and Piehl, 2007; Bell et al., 2013; Bell and Machin, 2013). This study focuses on the EU enlargement. The population migrating in this enlargement differs from the previous European studies that consider refugee populations, because these migrants are choosing where to migrate and when. This difference yields a better understanding

\footnotetext{
${ }^{1}$ Countries that were members before 2004.
} 
Figure 2.1: Timeline of the European Union Enlargements. Source: Delbecq and Waldorf (2010) and European Union (2013)

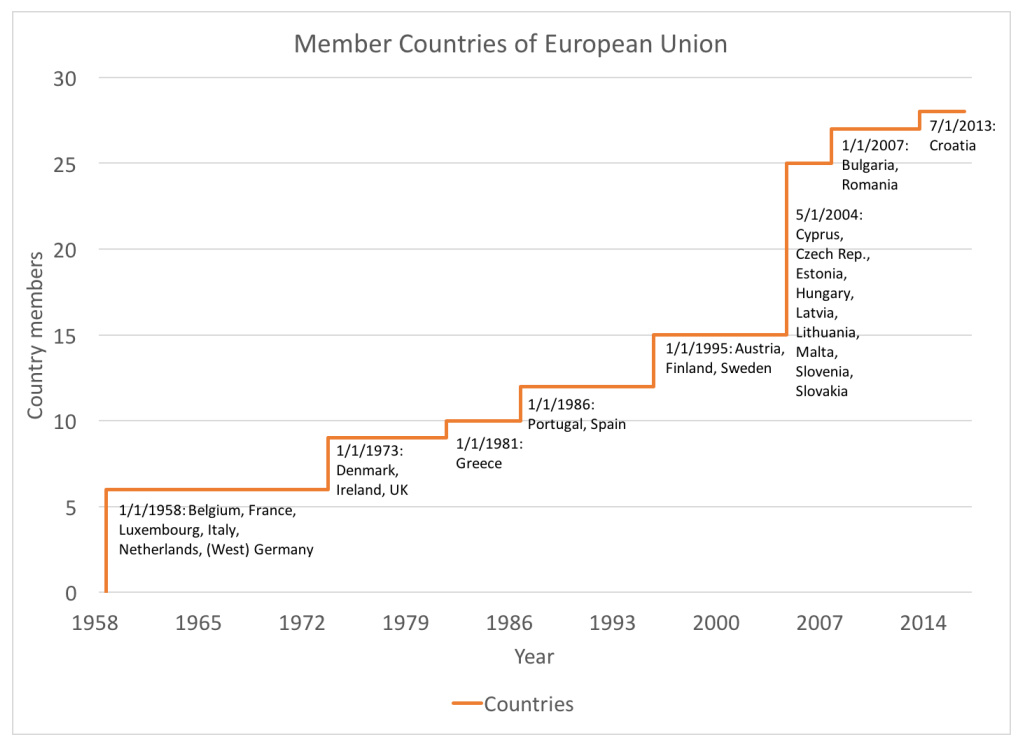

of the expected effect of the EU enlargement on countries' crime rates. Furthermore, the evidence for European migration has mainly focused on the United Kingdom. This chapter focuses on Italy and Spain. These countries are more accessible for migrants, who face lower transportation costs to move compared with moving to the United Kingdom.

I develop a panel of data to study the effect of increased immigration on crime rates. The panel focuses on the period from 2003 to 2008 . This period was chosen to avoid the effects of the 2009 crisis when many likely were forced into illegal activities to overcome the difficult economic situation. The results suggest that, after controlling for other variables that correlate with crime, the increase in immigration did not increase crime rates.

This chapter is divided into six sections: Following this Introduction, I review the associated literature. Then I describe the methodological approach and the data. In 
Figure 2.2: Total Foreign Born Population by Country. Source: European Union (2013)

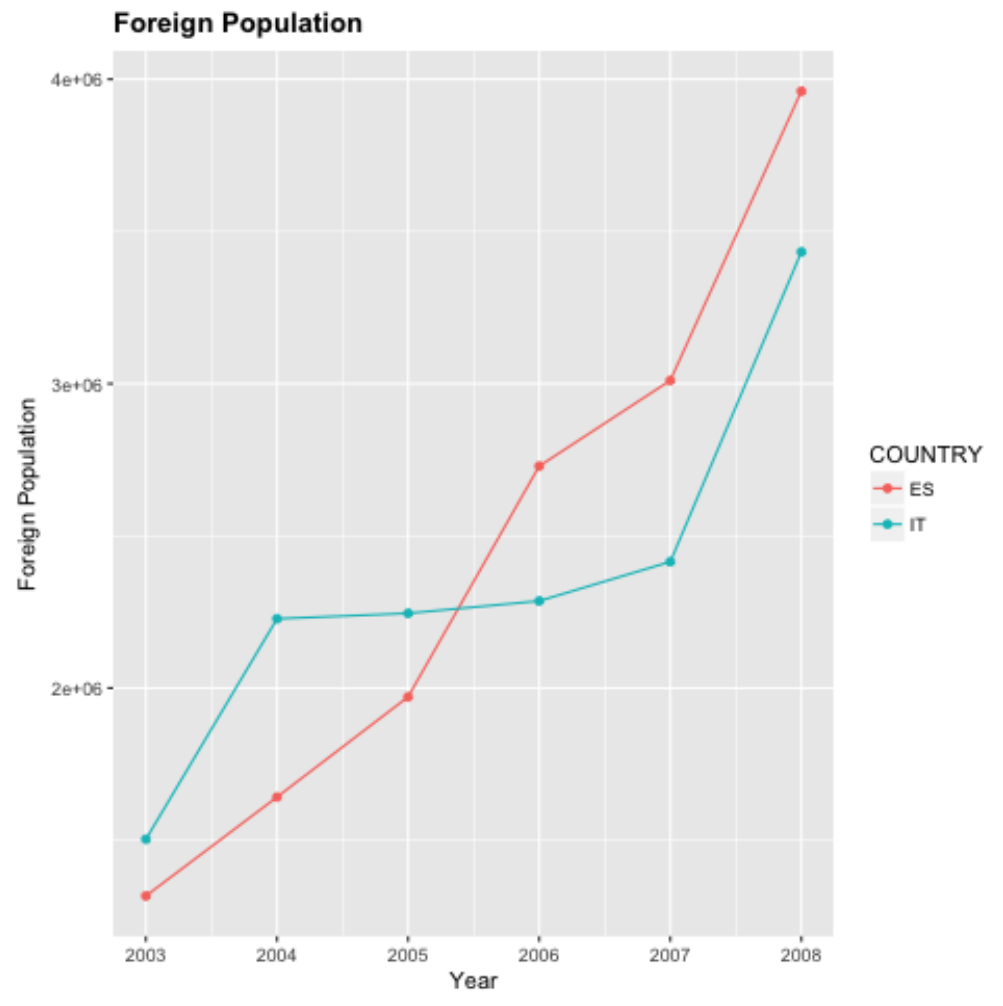

the last two sections, I present the results and draw conclusions.

\subsection{Theoretical and empirical literature}

Some recent studies have found a positive linkage between immigration and all criminal activities, property crime, or incarceration rates, while others have found the connection to be insignificant. These studies have focused mainly on the United States and European countries, due to the large number of immigrants that move to these countries. These countries have been at the center of political discussions related to their immigration policies. Some politicians have expressed strong feelings against foreigners and blamed immigration for higher crime rates. Research provides an opportunity to step away from these emotional reactions. I begin by discussing the theoretical 


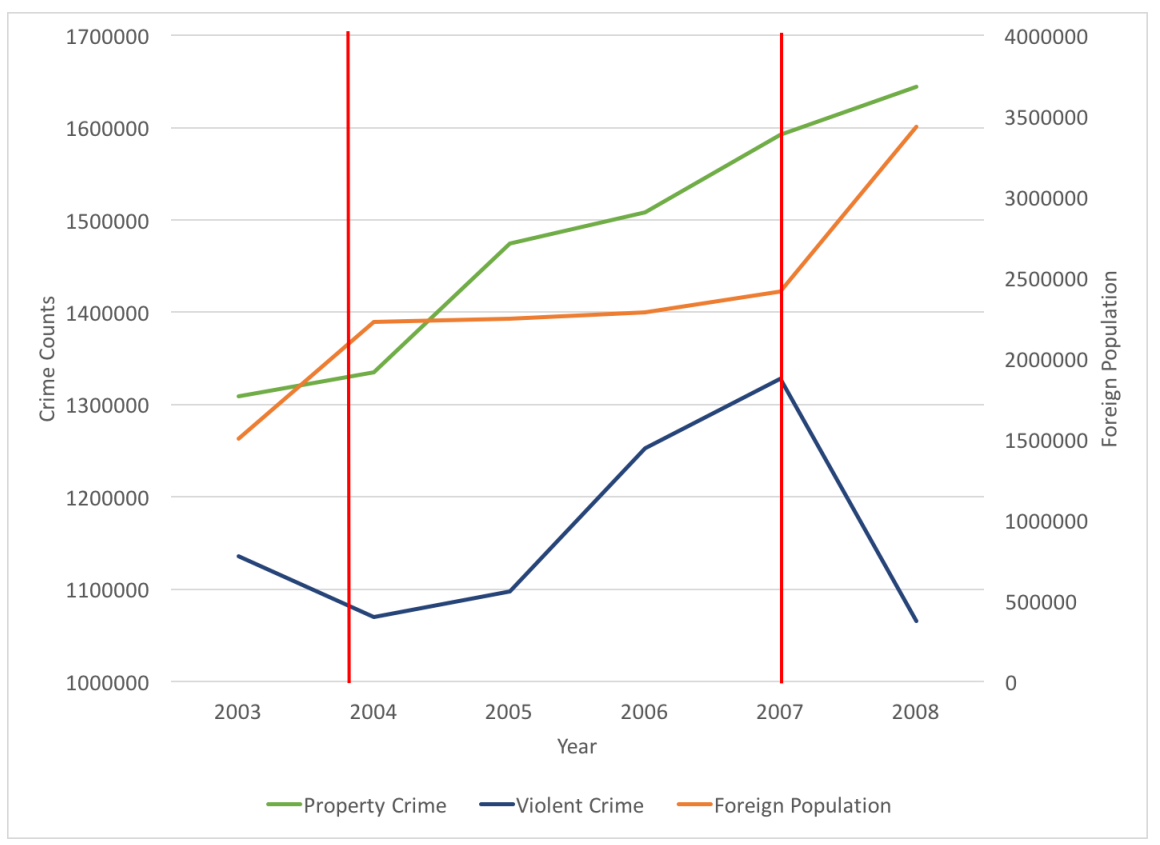

Figure 2.3: Crime Counts and Foreign Population in Italy. Source: Italian National Institute of Statistics (ISTAT)

basis for understanding the relationship between immigration and crime. Then I turn to a discussion of the current empirical literature.

Since Becker (1968), studies of the determinants of crime identify the benefits and costs of committing criminal activities. Spenkuch (2014), based on Becker's arguments, explains that if the expected utility from committing a crime differs between immigrants and natives and the outside options are worse for immigrants, the number of crimes and the crime rate should increase as the number of immigrants increases. However, Butcher and Piehl (1998) argued that immigrants face higher costs of criminal activity as they may serve longer terms than natives, either because they are given longer sentences or are less likely to be paroled.

Demographic characteristics are another potential link between immigration and crime. Immigrants tend to be young (between ages of 15 and 25) and are more likely to 


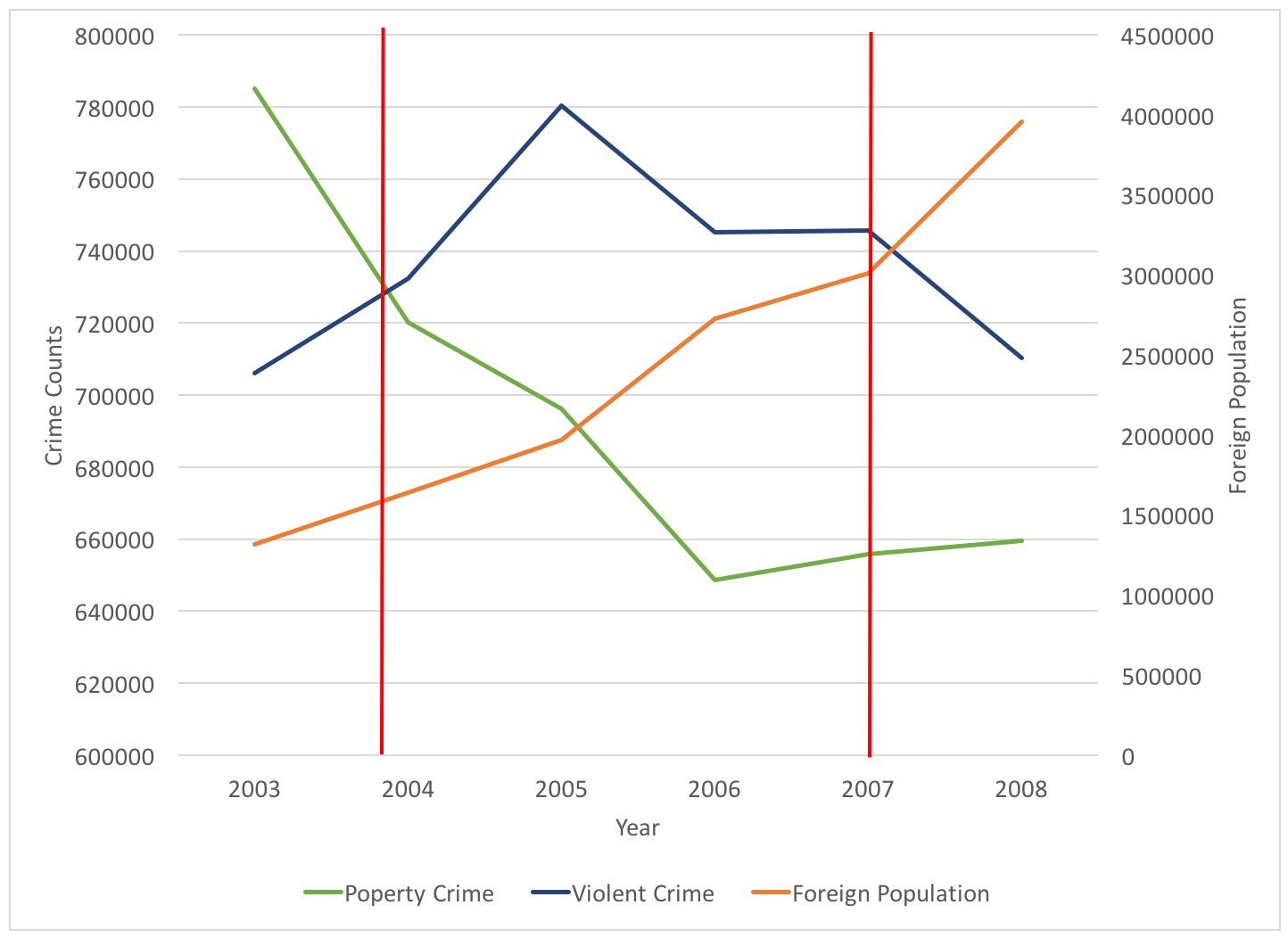

Figure 2.4: Crime Counts and Foreign Population in Spain. Source: the Department of State of Spain, and the National Institute of Statistics of Spain (INE)

be male. This demographic is more prone than other groups to be involved in criminal activity (Moehling and Piehl, 2007; Spenkuch, 2014).

Butcher and Piehl (1998) also argued that immigrants may have an adverse impact on crime by crowding natives out of the legal sector. If immigrants adversely affect natives' legal alternatives by taking jobs or overburdening the welfare system, low-skilled natives may increase their involvement in criminal activities. The authors state that this relationship also found that immigrants are more likely than natives to commit crimes when they are unable to be employed because of cultural difficulties and lack of a supportive network. The authors explain that immigrants may be more likely to be apprehended or convicted than natives because immigrants do not have the the same 
legal knowledge.

Additionally Le Brun (2008) analyzed the channels of social disorganization theory and the way they affect immigrants and their relationship with crime. Le Brun (2008) stated that "According to social disorganization theory, four factors weaken the informal controls against crime: poverty, ethnic heterogeneity, residential mobility, and family." Immigrants usually have a lower income than the natives, have a different origin which contributes to ethnic heterogeneity, have moved away from their place of origin, and are more likely to be far from their family. However, Le Brun (2008) explained that immigrants could be related to fewer criminal activities in the case of the United States, because the social disorganization theory does not affect immigrants, whose experiences as migrants modify their view of their living conditions.

The arguments espoused by Le Brun (2008) apply to the EU enlargement immigrants because these immigrants faced conditions similar to immigrants in the United States. According to Lebrun's arguments, immigrants to the EU area earn an average income lower than natives. However, the earnings are higher in the host country than in their home country, in which case they might not consider themselves as poor (see Table 2.1). Immigrants contribute to ethnic heterogeneity. However, immigrants tend to locate in areas where other immigrants live so that they are not singled out. They sometimes separate themselves from family. However, they usually find in their host country a group of people who serve as their "foster family" so that they do not feel so alone. However, migrants to the EU countries do not need to get a visa, which reduces both the requirements and the costs to migrate.

The empirical literature offers mixed results. As already stated, some show a positive relationship, while the majority have found insignificant relationships between crime and immigration. Positive results have been found by Borjas et al. (2006), Bianchi et al. (2012) and Spenkuch (2014). Borjas et al. (2006) explored the crowding out effect 
in the labor market. Borjas et al. (2006) found evidence that immigration crowded out low-skilled workers (black men). As the number of immigrants increased, the wage of low-skill black workers fell, their employment rate declined, and their incarceration rate rose. Spenkuch (2014) estimated a panel of counties in the United States from 1980 to 2000 and found evidence of a positive relationship between crime and immigration. This result is stronger when studying crimes that involved an economic gain or loot from the criminal activity.

Other studies, such as Bianchi et al. (2012), found evidence that increased immigration to Italian provinces affected only property crimes significantly. Their analysis showed that crimes related to financial gain have a positive correlation even after including instruments. The authors highlighted as motives for increased crime the fact that immigrants to Italian provinces face lower wages and had lower legitimate earning opportunities because of their different demographic characteristics. However, their cost for crime could be greater because of the probability of incarceration.

Analyses for the United Kingdom were presented by Bell and Machin (2013) and Bell et al. (2013). Bell and Machin (2013) find a significant positive correlation between immigration and property crime in the United Kingdom. This result is significant after controlling for other correlated variables. However, this relationship was only related to asylum seekers and specifically to males. They also found positive correlation between arrest rates and the share of population coming from the EU countries that entered in 2004. Bell et al. (2013) also found a positive correlation between property crimes and the wave of immigration from 1990-2000 in the United Kingdom as well as a small negative impact for the immigration wave post the 2004 enlargement of the European Union. Their results are explained by differences in labor market opportunities for the different migrant groups.

Some papers have not found evidence of a significant correlation between crime and 
immigration; Butcher and Piehl (1998) and Le Brun (2008) focused on Metropolitan Statistical Areas in the United States and found, after instrumenting, that the correlation is not significant. Jaitman and Machin (2013) found similar results for England and Wales. Their paper included immigration into England and Wales from the first EU enlargement analyzed in this article (2004).

A recent trend in research has focused on the legal status of immigrants and criminal activities. Mastrobuoni and Pinotti (2015) have the only paper that has explored the re-arrest probabilities based on the EU enlargement of 2004. Their results show that recidivism decreases, but mainly in places where labor opportunities for immigrants are better. The ideas by D'Amuri and Peri (2014) on the immigration consequences on the European labor market also support this result. The authors explain that routine jobs are taken by immigrants while low-skill natives take on more complex jobs. Baker (2015) uses time-series analysis to examine the efects of the Immigration Reform and Control Act (IRCA) from 1986 in the United States and its relationship with all crimes, violent crimes, and property crimes. The results showed a negative correlation, which was stronger for property crimes. Nunziata (2015) also explored the effect of legal status and the victimization and perception of crime in the European Union countries. Nunziata (2015) showed that an increase in the number of immigrants does not affect victimization, but is positively correlated with an increase in fear of crime.

These results leave the possible effect open to question because there could be specific conditions where crime has increased or particular scenarios in the labor market that could be relevant for study. Studying immigration into Italy and Spain differs substantially from the cases of the United States and the United Kingdom with respect to costs of migration. Immigrants need to apply for a visa to achieve access into the United States, while immigrants into the United Kingdom faced higher settlement costs compared to the other countries in the European Union. This likely results in the selection bias of immigrants to these countries. 


\subsection{Estimation methodology}

I estimate a panel data model of crime and immigration. The logarithm of the crime rate $(\operatorname{Ln}(C R))$ is the dependent variable, where the crime rate $(\mathrm{CR})$ is defined as the sum of crimes in time $t$ and administrative unit $i$ divided by the population for the same $t$ and $i$. The model uses the logarithm of the crime rates (dependent variable) and the independent variables. This transformation allows us to find the constant elasticity as the coefficient:

$$
C R_{i t}=\frac{\# \text { Crimes }_{i t}}{\text { Population }_{i t}}
$$

The model uses the share of immigrants $(S I)$ in the region as an independent variable. The share of immigrants $(S I)$ is defined as:

$$
S I_{i t}=\frac{\text { Immigrants }_{i t}}{\text { Population }_{i t}}
$$

The model to estimate is:

$$
\operatorname{Ln}\left(C R_{i t}\right)=\beta_{0}+\beta_{1} S I_{i t}+\alpha X_{i t}+u_{i t}
$$

where $X_{i t}$ is a set of time varying regional controls. They are included according to previous studies that analyze the determinants of crime. The list of $X_{i t}$ control variables includes the natural logarithm of the Gross Regional Product by Region $(\log (G R P))$, share of male population(PCTMale), rate of unemployment(Unemployment), fraction of young population ${ }^{2}(P C T 15-24)$, and the natural logarithm of the density of

\footnotetext{
${ }^{2}$ I include the share of population between the ages of 15 to 24 . The models were estimated using the population between 20 to 24 years old; however, the results are better using the group from 15 to 24.
} 
population $(\log ($ Density $))$.

Most of the panel data models use a one-way error component (see equation (2.4)), designated as the $u_{i t}$. It will be split into $\mu_{i}$, also known as the unobservable individualspecific effect, and $v_{i t}$, the disturbance after accounting for the effect (Baltagi, 2005). Panel data methodologies suggest two ways to address these effects. The first is the fixed effects model, which assumes that the $\mu_{i}$ are parameters fixed to be estimated and the $v_{i t}$ are disturbances that are stochastic, independent, and identically distributed $\operatorname{IID}\left(0, \sigma_{v}^{2}\right)$. The second method is the random effects model. The assumption in the random effects model is that $\mu_{i t} \sim \operatorname{IID}\left(0, \sigma_{\mu}^{2}\right), v_{i t} \sim \operatorname{IID}\left(0, \sigma_{v}^{2}\right)$, and $\mu_{i t}$ is independent of $v_{i t}$. The selection of which effect to use is done by using the Hausman test (Baltagi, 2005). Baltagi (2005) explains that the Hausman test is based on the difference between the fixed and random effects estimators.

$$
u_{i t}=\mu_{i}+v_{i t}
$$

The Hausman test compares the coefficients from random and fixed effects estimators under the null hypothesis that both models are consistent. Rejection will mean that the random effects is not consistent and asymptotically efficient under the $H_{0}$ (Hausman, 1978; Baltagi, 2005).

This specification has certain issues: the first one could be reverse causality, because immigrants may avoid cities with high crime rates (de Sousa, 2014). This issue will bias $\beta_{1}$ downwards. The second issue is that the intensity of immigration has a correlation with other variables that help explain variation in crime, such as employment rates and wages (Harris and Todaro, 1970; Borjas et al., 2006). The inclusion of these variables may not allow observation of the effect of immigration on crime rates and yet excluding them could lead to omitted variable bias (Le Brun, 2008). 
Another issue is the potential for measurement errors when accounting for the number of immigrants, especially with a transient population and illegal immigrants. This issue could affect the $\beta_{1}$ and create a bias, which could be either positive or negative. Another measurement error issue comes from crime data, which might suffer from under reporting. Also there is a lot of variation in reporting standards between regions. In this case, large cities could report less crime and the crime rates will be downwardly biased, which will bias the effect estimated from immigration rates in the OLS approach and the instrumental variable estimations. However this issue could be present in all crime models.

All these issues are consistent with endogeneity of some right-hand regressors (Baltagi, 2005). Baltagi (2005) describes this as the correlation between the right-hand side regressors and disturbances in a panel data model and argues that this might be due to all described issues. The solution to most of these issues comes from instrumental variable methodology. This approach uses an instrumental variable to solve the problem of possible endogeneity. The instrumental variable used was defined by Saiz (2007) and Le Brun (2008). Equation (2.5) represents the instrumental variable used in the model to solve the endogeneity problem. The instrument (Inst) considers the participation of immigrants $(P I)$ in region $i$ over all the immigrants during the previous CENSUS ${ }^{3}$ and the Share of Immigrants $(S I)$ of total population in the current year $t$ for region $i$. This type of instrument depends on the assumption that the locations where immigrants settle do not change by "persistent shocks" over time and are uncorrelated with crime variables (Jaitman and Machin, 2013). Additionally it states that immigrants move to areas with other immigrants. Furthermore, the advantage from such an instrument is that current crime rates will not affect the past regional distribution of migrants because it will solve the issue of reverse causality. The instrumental variable is defined as:

\footnotetext{
${ }^{3}$ The previous census that I use was from the year 1991 for both countries.
} 


$$
\text { Inst }_{i, t}=\left(S I_{i t}\right) \times\left(P I_{i, 1991}\right)=\left(\frac{\text { Immigrants }_{i t}}{\text { Population }_{i t}}\right)\left(\frac{\text { Immigrants }_{i, 1991}}{\sum_{i=1}^{N} \text { Immigrant }_{i, 1991}}\right)
$$

The regressions results from this analysis will include the model estimated for All Crimes (Total Crimes), Property Crimes, and Violent Crimes. Each regression considers the effect of the different variables on the crime rate by type of crime.

Further evaluations of changes in immigrant populations require that we explore the increases in the number of immigrants from specific groups of regional origins. We estimate the increases of immigrant population from three large groups of nationalities. The three regions that I use to explore the increases in these populations are European, African and South and Central American countries (Latin American). Keep in mind that the only group that should have abruptly increased the inmigration flow is the European population. These groups have been targeted and blamed for causing crime increases previously by politicians and other groups. These three regions are considered related to increases in crime in Europe and United States. However, due to the enlargement of the EU regions, the number of immigrants increased (see figure 2.2), because citizens from European countries faced a decrease in the requirements to enter the EU countries.

The model to estimate the particular effect of the increase of a specific group of immigrants divides the immigrant population into the specific group and the rest of the immigrants. Equation (2.6) divides the migrant population variable into the share of immigrants from Europe, Africa, and Latin America (SIxr), and the share of the rest of the immigrants (SIrestr) (Le Brun, 2008). Where the $x=\{$ Europe, Africa, Latin America $\}$.

$$
\operatorname{Ln}\left(C R_{i t}\right)=\beta_{0}+\beta_{1} \text { SIxr }_{i t}+\beta_{2} \text { SIrestr }_{i t}+\alpha X_{i t}+u_{i t}
$$

The analysis proposed in equation (2.6) has the same issues described above. It 
requires instrumental variables for $($ SIxr) and (SIrestr). The instrument for for the Share of Immigrants from region $\mathrm{X}$ (Instxr) in equation (2.7) uses the share of immigrants from region $X$ and the participation of immigrants in the region over all the regions from the 1991 Census. The instrument for the Share of Immigrants from the rest (Instrestr) in equation (2.8) uses the share of immigrants from the rest of regions and the participation of immigrants in the region over all the regions from the 1991 Census (Le Brun, 2008). This instrument is similar to the one used by Le Brun (2008), however, it was not possible to find population by region for all regions in the 1991 census.

Instxr $_{i, t}=\left(S I_{i t}\right) \times\left(P I_{i, 1991}\right)=\left(\frac{\text { Immigrants from }_{i t}}{\text { Population }_{i t}}\right)\left(\frac{\text { Immigrants }_{i, 1991}}{\sum_{i=1}^{N} \text { Immigrants }_{i, 1991}}\right)$

Instrest $_{i, t}=\left(S I_{i t}\right) \times\left(P I_{i, 1991}\right)=\left(\frac{\text { Immigrants from rest }_{i t}}{\text { Population }_{i t}}\right)\left(\frac{\text { Immigrants }_{i, 1991}}{\sum_{i=1}^{N} \text { Immigrant }_{i, 1991}}\right)$

\subsection{Data description}

The data used in this chapter are from a yearly panel of NUTS2 regions ${ }^{4}$ of two European countries: Italy and Spain. The data panel includes observations from 2003 to 2008. Information on regional economic characteristics is published by Eurostat and the National Institutes of Statistics from each country. The panel consists of six years of data for two countries and 39 NUTS2 regions per year.

\subsubsection{Dependent variables}

The crime rates are calculated using equation (2.1), which measures the crimes per person by administrative unit. The crime information utilized for the estimation comes

\footnotetext{
${ }^{4}$ According to Eurostat, NUTS2 areas are basic regions for the application of regional policies (European Union, 2013).
} 
from different sources for each country, such as annual police reports and reports from the ministry of the interior and specific crime agencies. All information is published for NUTS 2 areas. Crimes are classified into two broad categories: property crime and violent crime. I have three measures of crime: total crime, property crime, and violent crime.

Total crime includes all crimes and is the sum of property crime and violent crime. Property crime includes all crimes that involve money, property, or some other benefit: burglary, larceny, theft, motor vehicle theft, arson, shoplifting, and vandalism. Violent crimes includes all crimes for which the offender uses or threatens to use force upon a victim: murder, nonnegligent manslaughter, forcible rape, assault, robbery, and aggravated assault. Total crime averages 104,259.5 crimes per NUTS 2 administrative unit and year, with a standard deviation of $115,258.8$. Property crimes have a mean of $55,676.97$ crimes, with a standard deviation of $65,424.93$. The crime types are defined in a similar way for both countries so that they can be comparable between units.

\subsubsection{Independent variables}

The independent variables included are controls and migration variables. The variables used to account for migration come from national institutes of statistics from each country. These institutions report the number of foreign people living in each region. The foreign population includes all the population that does not have the country's citizenship, e.g., the population that was born outside of Italy and does not have Italian citizenship.

This foreign population is by classification of the region of birth for each NUTS2 unit. The average Share of Immigrant population in the NUTS2 regions is 4.365 percent, and the standard deviation is 2.897 percent. The presence of illegal immigrants creates a measurement error or undercount of immigrants. This is addressed by using the instrumental variable approach. 
The controls include the Population Density, Real Gross Domestic Product, Unemployment Rate, Percentage of Young Population, and Percentage of Male Population. These variables are available on the Eurostat website, and all of these variables are available for NUTS2 regions (European Union, 2013). Table 2.2 presents the summary statistics for the variables used in the analysis.

Table 2.1: GDP per capita in European Countries. Source: EUROSTAT.

\begin{tabular}{lccc}
\hline \hline \multicolumn{1}{c}{ Country } & Member since & GDP Per capita & GDP Per capita \\
& & 2006 & 2007 \\
\hline Cyprus & 2004 & 23600 & 24200 \\
Czech Republic & 2004 & 14400 & 15200 \\
Estonia & 2004 & 12200 & 13300 \\
Hungary & 2004 & 10200 & 10300 \\
Latvia & 2004 & 9200 & 10200 \\
Lithuania & 2004 & 8700 & 9800 \\
Malta & 2004 & 15000 & 15500 \\
Poland & 2004 & 8000 & 8600 \\
Slovakia & 2004 & 10700 & 11900 \\
Slovenia & 2004 & 17500 & 18600 \\
Bulgaria & 2007 & 4500 & 4900 \\
Romania & 2007 & 5600 & 6100 \\
Croatia & 2013 & 10700 & 11200 \\
Austria & Before 2004 & 34500 & 35700 \\
Belgium & Before 2004 & 33100 & 34000 \\
Denmark & Before 2004 & 46000 & 46200 \\
Finland & Before 2004 & 35500 & 37200 \\
France & Before 2004 & 31000 & 31500 \\
Germany & Before 2004 & 31000 & 32100 \\
Greece & Before 2004 & 22000 & 22700 \\
Ireland & Before 2004 & 39800 & 40700 \\
Italy & Before 2004 & 28500 & 28700 \\
Luxembourg & Before 2004 & 77800 & 82900 \\
Netherlands & Before 2004 & 37600 & 38900 \\
Portugal & Before 2004 & 16800 & 17200 \\
Spain & Before 2004 & 24100 & 24500 \\
Sweden & Before 2004 & 39300 & 30400 \\
United Kingdom & Before 2004 & 30000 & \\
\hline & & & \\
\hline
\end{tabular}


Table 2.2: Descriptive Statistics.

\begin{tabular}{lcccc}
\hline \hline Statistic & Mean & St. Dev. & Min & Max \\
\hline Total Crimes & $104,259.500$ & $115,258.800$ & 1,712 & 553,847 \\
Property Crimes & $55,676.970$ & $65,424.930$ & 510 & 328,267 \\
Violent Crimes & $48,582.510$ & $51,868.390$ & 1,086 & 237,933 \\
Population & $2,614,262.000$ & $2,315,105.000$ & 120,909 & $9,642,406$ \\
Density & 273.231 & 676.307 & 22.700 & $4,433.254$ \\
GDP & $63,416.900$ & $64,415.640$ & 2,374 & 327,829 \\
Unemployment rate & 0.085 & 0.044 & 0.018 & 0.250 \\
Share population in age $15-24$ & 0.111 & 0.019 & 0.075 & 0.158 \\
Share of Male Population & 0.490 & 0.008 & 0.472 & 0.507 \\
Foreign Population & $122,821.200$ & $157,841.600$ & 2,114 & 860,575 \\
Foreign from Europe & $53,935.850$ & $63,936.820$ & 146 & 305,068 \\
Foreign from EU 15 & $16,517.570$ & $26,038.120$ & 89 & 136,202 \\
Foreign from Center & $35,916.910$ & $47,503.500$ & 19 & 267,639 \\
and East Europe & & & & \\
Foreign from Other & $1,501.372$ & $5,072.179$ & 3 & 54,424 \\
European Countries & & & & \\
Foreign from Africa & $27,088.770$ & $42,085.430$ & 8 & 266,542 \\
Foreign from Latin & $25,074.220$ & $46,690.880$ & 37 & 285,534 \\
America & & & & \\
\hline
\end{tabular}

\subsection{Results}

Tables 2.3, 2.5, and 2.7 show that the panel models selected should be random effects models. The first column in Tables 2.3, 2.5, and 2.7 reveals that all models need to include individual fixed effects estimates because the $\mathrm{F}$ test for the presence of fixed effects rejects the null hypothesis. The second column of the Tables 2.3, 2.5, and 2.7 confirm that the fixed effects model with individual effects does not need to include time fixed effects. The models that test for the need to include time effects does not reject the null hypothesis. The third column tests the presence of random effects against the pooled model. Finally the fourth column shows the Hausman tests, the Hausman tests do not reject the null hypothesis, and this evidence suggests using random effects models might be adequate. 
Table 2.3: Testing procedures to the Panel models.

\begin{tabular}{lcccc}
\hline \hline \multicolumn{4}{c}{ Total Crimes and All foreigns panel model } \\
\hline & F Test for & F Test for & Breusch-Pagan & Hausman \\
Individual & Time & Lagrange Multiplier & Test \\
& Fixed Effects & Fixed Effects & for random effects & \\
\hline Test & 213.28 & 2.429 & 444.13 & 1.8122 \\
p-value & 0.000 & 0.119 & 0.000 & 0.9361 \\
\hline \hline Note: & & & ${ }^{*} \mathrm{p}<0.1 ;{ }^{* *} \mathrm{p}<0.05 ;{ }^{* * *} \mathrm{p}<0.01$
\end{tabular}

This result is similar to the reassessment done by Baltagi (2006) to the crime panel model of North Carolina. Baltagi (2006) suggests that to test for a contrast between fixed and random effects you have to consider the endogeneity of the independent variables. Baltagi (2006) also explains that the usual Hausman test leads to a misleading inference among the regressors and proposes an alternative version of the Hausman test based on the effects estimated using instrumental variables. The application of this methodology provides results that support using the random effects model.

The regression results that relate immigration and total crime in the EU region are in Table 2.4. The first column of results is for the pooled model, which does not include effects estimates and shows a bias in the coefficient associated with the share of immigrants. The model shows a positive correlation between Total Crime and the share of immigrants in the NUTS 2 regions in the pooling model. Columns two and three include the fixed effects models. Both models show interesting results for the significance of the share of immigrants and other controls included. Previous research has always used fixed effects models and found similar results to the results in Table 2.4. Finally the fourth column includes the random effects models which, according to the testing results, is the model that fits best the results. The model with random effects shows a positive relationship between GDP and total crime, and another positive relationship between the share of population between the ages of 15 and 24. Furthermore, there is a negative and non-significant coefficient associated with the share of immigrants. 
Table 2.4: Panel Model Results for Total Crimes. Results in parenthesis are the standard errors.

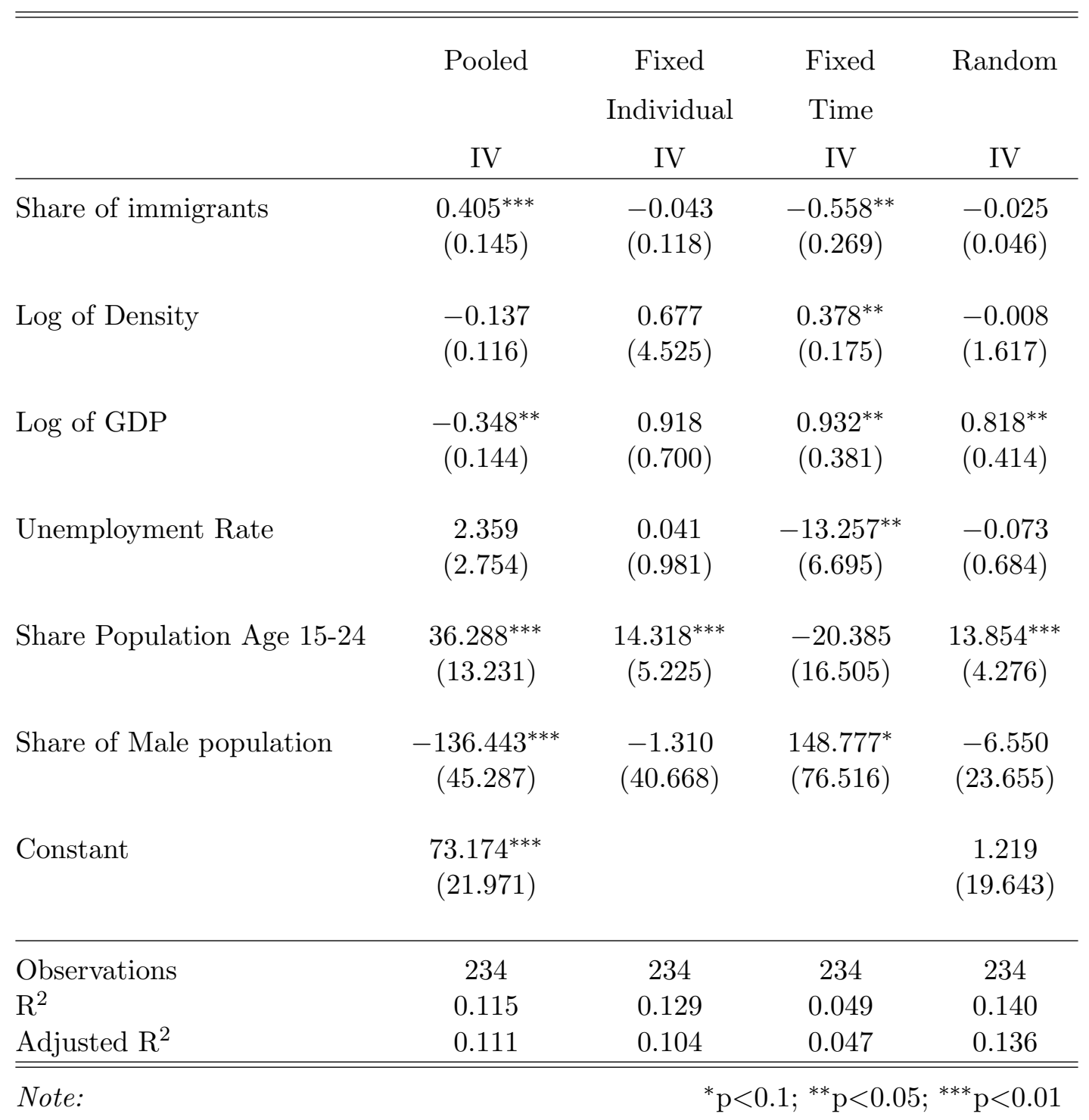

$=$ The regression results focused on property crime are in table 2.6. The pooling model also exhibits a positive and significant correlation between the Rate of foreign and the crime rate. This bias disappears with the fixed effects models (similar to previous research). The random effects model reveals that the coefficient that correlates property crime and GDP is positive and significant, as the criminals will commit more 
Table 2.5: Testing procedures to the Panel models

\begin{tabular}{lcccc}
\hline \hline \multicolumn{4}{c}{ Property Crimes and All foreigns panel model } \\
\hline & F Test for & F Test for & Breusch-Pagan & Hausman \\
& Individual & Time & Lagrange Multiplier & Test \\
& Fixed Effects & Fixed Effects & for random effects & \\
\hline Test & 235.560 & 2.779 & 264.820 & 0.451 \\
p-value & 0.000 & 0.095 & 0.000 & 0.998 \\
\hline \hline Note: & & & ${ }^{*} \mathrm{p}<0.1 ;{ }^{* *} \mathrm{p}<0.05 ;{ }^{* * *} \mathrm{p}<0.01$
\end{tabular}

crimes when the payout from such offenses could be higher, and the coefficient for the share of the population between the age of 15 and 24 is also positive and significant. Finally, the coefficient associated with the percentage of immigrants is negative and not significant.

Table 2.8 shows the results for violent crimes. The pooled model results also find a positive and significant correlation between the share of immigrants and the crime rate for violent crime and the fixed effects models also find a negative coefficient which is only significant in the case of time fixed effects. The random effects model reveals a positive and non-significant coefficient for immigrant share, while the coefficients associated with the GDP and the share of young population have positive and significant coefficients.

The results from the three random effects models indicate that the increase in foreign population is not associated with the increases in crime rates for the different NUTS 2 regions. Crimes are positively associated with GDP and the share of young population.

The individual analysis for different regional groups of origin are presented in Tables $2.9,2.10$, and 2.11. The groups analyzed include only immigrants coming from 
Table 2.6: Panel Model Results for Property Crimes. Results in parenthesis are the standard errors.

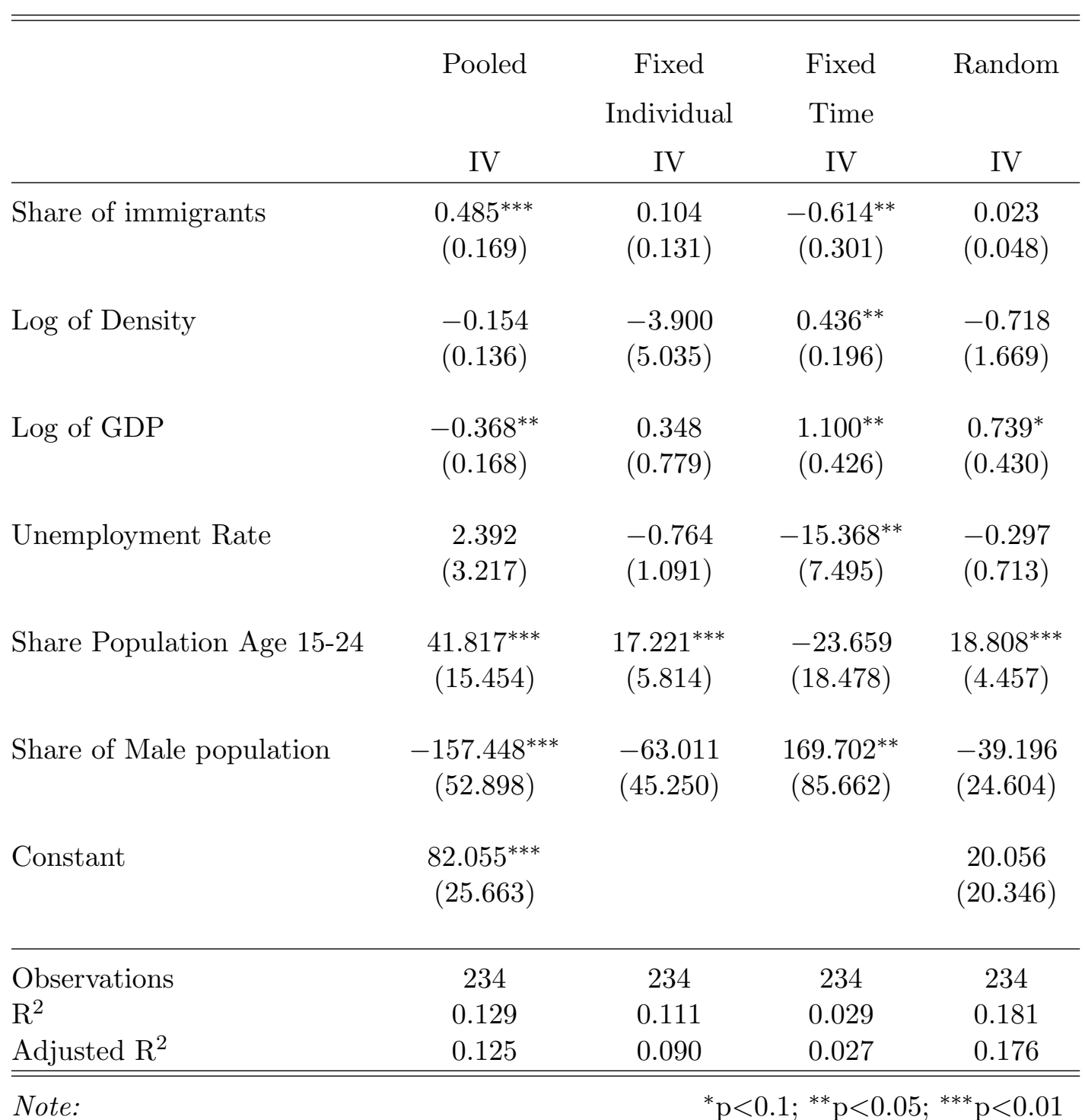

European countries, Latin American countries, and African countries ${ }^{5}$. The results included in Tables 2.9, 2.10, and 2.11 are the random effects models. The three columns show the coefficients and standard errors.

Table 2.9 shows the regression results focused on how the share of immigrants from

\footnotetext{
${ }^{5} \mathrm{I}$ do not include immigrants from the Middle East, because the number of immigrants from this origin is very low.
} 
Table 2.7: Testing procedures to the Panel models

\begin{tabular}{lcccc}
\hline \hline \multicolumn{4}{c}{ Data Panel Testing results for model Violent Crimes and All foreigns } \\
\hline & F Test for & F Test for & Breusch-Pagan & Hausman \\
& Individual & Time & Lagrange Multiplier & Test \\
& Fixed Effects & Fixed Effects & for random effects & \\
\hline Test & 48.023 & 2.167 & 281.610 & 0.451 \\
p-value & 0.000 & 0.141 & 0.000 & 0.998 \\
\hline \hline Note: & & & ${ }^{*} \mathrm{p}<0.1 ;{ }^{* *} \mathrm{p}<0.05 ;{ }^{* * *} \mathrm{p}<0.01$
\end{tabular}

European countries affects the three crime categories. Random effects models reveal that the increase in the share of immigrants immigrants has a positive and significant relationship only with property crimes, with an insignificant effects on all crimes and violent crimes. The correlation observed for GDP and share of young population is positive and significant. The coefficient for foreign population from the rest of the world is negative and significant. This result suggests a positive relationship between arrival of immigrants and property crimes only, which could be related to the economic necessities from immigrants and crowded-out low skilled workers.

Tables 2.10 and 2.11 include the regression results for the other two groups that have been associated with criminal activities by locals (Latin Americans and Africans). The results associated with these two groups show a negative and significant relationship associated with the immigration of Latin Americans and Africans. The coefficients associated with GDP show a positive and significant relationship with property crimes. The results for GDP and the share of the population age 15 to 24 are positive and significant for the analysis using the share of African immigrants and not significant for the case of Latin American immigrants. 
Table 2.8: Panel Model Results for Violent Crimes. Results in parenthesis are the standard errors.

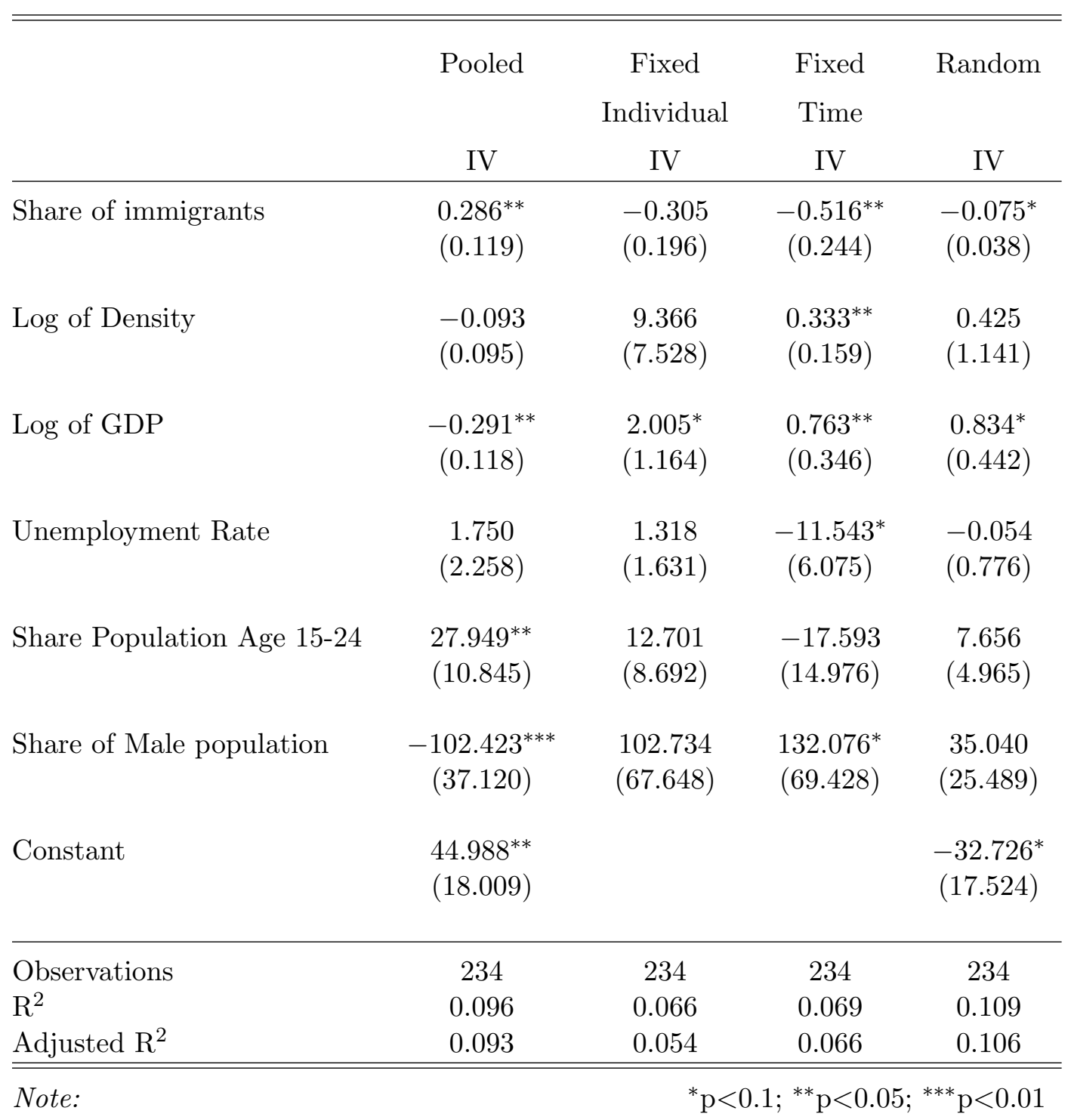

\subsection{Conclusions}

This chapter explores one quasi-natural experiment regarding the possible effects on crime from the EU enlargement. Since the EU enlargement, we have seen a yearly increase of approximately 26 percent of immigrants going to Italy and Spain (see figure 2.2). The number of immigrants doubled in the period from 2003 to 2008. The number of crimes also increased during the same period. The current approach includes other 
Table 2.9: Panel Model Results for All types of Crimes using European immigrants. All results use the random effects model. Results in parenthesis are the standard errors.

\begin{tabular}{|c|c|c|c|}
\hline & $\begin{array}{c}\text { All Crimes } \\
(1)\end{array}$ & $\begin{array}{c}\text { Property Crimes } \\
(2)\end{array}$ & $\begin{array}{c}\text { Violent Crimes } \\
(3)\end{array}$ \\
\hline Share of immigrants from Europe & $\begin{array}{c}0.033 \\
(0.031)\end{array}$ & $\begin{array}{l}0.073^{* *} \\
(0.032)\end{array}$ & $\begin{array}{l}-0.021 \\
(0.031)\end{array}$ \\
\hline Share of immigrants from not Europe & $\begin{array}{c}-0.081^{* *} \\
(0.033)\end{array}$ & $\begin{array}{l}-0.054 \\
(0.035)\end{array}$ & $\begin{array}{c}-0.102^{* * *} \\
(0.034)\end{array}$ \\
\hline Log of Density & $\begin{array}{l}-0.019 \\
(0.738)\end{array}$ & $\begin{array}{l}-0.178 \\
(0.793)\end{array}$ & $\begin{array}{c}0.080 \\
(0.504)\end{array}$ \\
\hline Log of GDP & $\begin{array}{l}0.713^{* *} \\
(0.355)\end{array}$ & $\begin{array}{l}0.699^{*} \\
(0.371)\end{array}$ & $\begin{array}{l}0.642^{*} \\
(0.375)\end{array}$ \\
\hline Unemployment Rate & $\begin{array}{c}0.049 \\
(0.642)\end{array}$ & $\begin{array}{l}-0.074 \\
(0.667)\end{array}$ & $\begin{array}{l}-0.074 \\
(0.743)\end{array}$ \\
\hline Share Population Age 15-24 & $\begin{array}{c}10.846^{* *} \\
(4.182)\end{array}$ & $\begin{array}{c}15.810^{* * *} \\
(4.347)\end{array}$ & $\begin{array}{c}4.728 \\
(4.755)\end{array}$ \\
\hline Share of Male population & $\begin{array}{c}1.889 \\
(20.999)\end{array}$ & $\begin{array}{l}-25.222 \\
(21.865)\end{array}$ & $\begin{array}{c}35.912 \\
(23.717)\end{array}$ \\
\hline Constant & $\begin{array}{l}-1.415 \\
(13.396)\end{array}$ & $\begin{array}{c}11.382 \\
(14.064)\end{array}$ & $\begin{array}{l}-29.153^{* *} \\
(13.808)\end{array}$ \\
\hline Observations & 234 & 234 & 234 \\
\hline $\mathrm{R}^{2}$ & 0.164 & 0.211 & 0.125 \\
\hline Adjusted $\mathrm{R}^{2}$ & 0.159 & 0.204 & 0.121 \\
\hline
\end{tabular}

control variables that affect crime and addresses the issue of a reverse causality with the instrumental variable approach.

The results show after including the other control variables and applying the instrumental variable approach, a negative but insignificant relationship between the 
Table 2.10: Panel Model Results for All types of Crimes for Latin immigrants. All results use the random effects model. Results in parenthesis are the standard errors.

\begin{tabular}{|c|c|c|c|}
\hline & $\begin{array}{c}\text { All Crimes } \\
(1)\end{array}$ & $\begin{array}{c}\text { Property Crimes } \\
(2)\end{array}$ & $\begin{array}{c}\text { Violent Crimes } \\
(3)\end{array}$ \\
\hline Share of immigrants from Latin America & $\begin{array}{c}-0.126^{* * *} \\
(0.044)\end{array}$ & $\begin{array}{c}-0.140^{* * *} \\
(0.046)\end{array}$ & $\begin{array}{c}-0.094^{*} \\
(0.050)\end{array}$ \\
\hline Share of immigrants from not Latin America & $\begin{array}{c}0.016 \\
(0.021)\end{array}$ & $\begin{array}{l}0.052^{* *} \\
(0.023)\end{array}$ & $\begin{array}{l}-0.028 \\
(0.023)\end{array}$ \\
\hline Log of Density & $\begin{array}{c}0.044 \\
(0.220)\end{array}$ & $\begin{array}{c}0.041 \\
(0.264)\end{array}$ & $\begin{array}{c}0.062 \\
(0.166)\end{array}$ \\
\hline Log of GDP & $\begin{array}{c}0.372 \\
(0.238)\end{array}$ & $\begin{array}{c}0.368 \\
(0.270)\end{array}$ & $\begin{array}{c}0.321 \\
(0.201)\end{array}$ \\
\hline Unemployment Rate & $\begin{array}{l}-0.378 \\
(0.633)\end{array}$ & $\begin{array}{l}-0.492 \\
(0.659)\end{array}$ & $\begin{array}{l}-0.442 \\
(0.732)\end{array}$ \\
\hline Share Population Age 15-24 & $\begin{array}{c}6.216 \\
(4.047)\end{array}$ & $\begin{array}{l}9.966^{* *} \\
(4.306)\end{array}$ & $\begin{array}{c}1.877 \\
(4.374)\end{array}$ \\
\hline Share of Male population & $\begin{array}{c}0.296 \\
(19.042)\end{array}$ & $\begin{array}{l}-18.972 \\
(20.382)\end{array}$ & $\begin{array}{c}18.837 \\
(19.280)\end{array}$ \\
\hline Constant & $\begin{array}{c}3.141 \\
(10.377)\end{array}$ & $\begin{array}{c}11.399 \\
(11.201)\end{array}$ & $\begin{array}{c}-17.077^{*} \\
(10.287)\end{array}$ \\
\hline Observations & 234 & 234 & 234 \\
\hline $\mathrm{R}^{2}$ & 0.097 & 0.159 & 0.065 \\
\hline Adjusted $\mathrm{R}^{2}$ & 0.093 & 0.154 & 0.062 \\
\hline
\end{tabular}

share of immigrants and all crimes, property crimes, and violent crimes. The coefficients associated with variables like GDP and share of young population are positive and significant; similar to results from previous literature. This lack of significance of immigrants shows that the increase in crime might not be necessarily related to the increase in immigration. However, when dividing the share of immigrants into regional 
Table 2.11: Panel Model Results for All types of Crimes for African immigrants. All results use the random effects model. Results in parenthesis are the standard errors.

\begin{tabular}{|c|c|c|c|}
\hline & $\begin{array}{c}\text { All Crimes } \\
\text { (1) }\end{array}$ & $\begin{array}{c}\text { Property Crimes } \\
(2)\end{array}$ & $\begin{array}{c}\text { Violent Crimes } \\
(3)\end{array}$ \\
\hline Share of immigrants from Africa & $\begin{array}{c}-0.158^{* * *} \\
(0.042)\end{array}$ & $\begin{array}{c}-0.118^{* * *} \\
(0.044)\end{array}$ & $\begin{array}{c}-0.176^{* * *} \\
(0.047)\end{array}$ \\
\hline Share of immigrants from not Africa & $\begin{array}{c}0.022 \\
(0.026)\end{array}$ & $\begin{array}{l}0.049^{*} \\
(0.028)\end{array}$ & $\begin{array}{l}-0.010 \\
(0.028)\end{array}$ \\
\hline Log of Density & $\begin{array}{l}-0.109 \\
(0.348)\end{array}$ & $\begin{array}{l}-0.150 \\
(0.372)\end{array}$ & $\begin{array}{c}0.015 \\
(0.236)\end{array}$ \\
\hline $\log$ of GDP & $\begin{array}{l}0.767^{* *} \\
(0.302)\end{array}$ & $\begin{array}{l}0.760^{* *} \\
(0.319)\end{array}$ & $\begin{array}{l}0.496^{*} \\
(0.262)\end{array}$ \\
\hline Log of Density & $\begin{array}{c}0.097 \\
(0.644)\end{array}$ & $\begin{array}{l}-0.065 \\
(0.675)\end{array}$ & $\begin{array}{l}-0.116 \\
(0.727)\end{array}$ \\
\hline Share Population Age 15-24 & $\begin{array}{c}14.713^{* * *} \\
(4.068)\end{array}$ & $\begin{array}{c}19.865^{* * *} \\
(4.272)\end{array}$ & $\begin{array}{c}6.043 \\
(4.317)\end{array}$ \\
\hline Unemployment Rate & $\begin{array}{c}-5.662 \\
(19.892)\end{array}$ & $\begin{array}{l}-31.622 \\
(20.887)\end{array}$ & $\begin{array}{c}22.673 \\
(20.641)\end{array}$ \\
\hline Share Population Age 15-24 & $\begin{array}{c}1.682 \\
(11.302)\end{array}$ & $\begin{array}{c}13.254 \\
(11.889)\end{array}$ & $\begin{array}{l}-21.050^{*} \\
(11.313)\end{array}$ \\
\hline Observations & 234 & 234 & 234 \\
\hline $\mathrm{R}^{2}$ & 0.129 & 0.149 & 0.108 \\
\hline Adjusted $\mathrm{R}^{2}$ & 0.124 & 0.144 & 0.104 \\
\hline F Statistic $(\mathrm{df}=7 ; 226)$ & -31.497 & -31.334 & -30.161 \\
\hline
\end{tabular}

groups of origin such as European, Latin American, and African, the results support that these immigrant groups are not related to total crimes and violent crimes. The random effects model revealed a positive and significant relationship between to the presence of European immigrants and property crime. 
The increase in immigrants to these two countries (Italy and Spain) presents an interesting quasi-experimental case, which differs significantly from the immigration into the United States, and England due to implicit selection bias in the costs to migrate. The results only find evidence partially similar to the previous literature that claims immigration is correlated with property crime because this result holds only for immigration from European countries. Additionally, D'Amuri and Peri (2014) propose an alternative explanation, they state that the immigrants join the labor market and take the low-skilled jobs while local workers take on more complex jobs. 


\section{Chapter 3}

\section{Determinants of Undocumented Immigrants' Choice to Locate in United States}

The decision of where to migrate and live by undocumented immigrants has important policy implications because the immigrants come to the labor market and affect the supply and demand for jobs as well as the utilities, education system, health, and other goods that are needed. This chapter analyzes the determinants that affect the location choice of undocumented immigrants. The analysis will consider economic and social variables that have been considered important in explaining migration.

Also, I set up a spatial panel model, this model allows us to consider spatial spillover effects that affect the decision of migrants when they select the state to which they are going to migrate to. The panel part of the model allows us to consider changes in time as part of the dynamic of population changes and velocity of increase in the share of undocumented immigrants. Previous immigration theories stated that migrants would move to locations where they can get a higher income or expect one (Sjaastad, 1962; Harris and Todaro, 1970), therefore we could expect that undocumented immigrants will consider their income expectations as well as other variables such as costs and risks 
Juan Tomás Sayago-Gómez Chapter 3. Determinants of Undocumented Immigrants' Choice 33

when choosing an location.

Migration of the undocumented population shares certain characteristics with the internal migration decision in developed and developing countries and other characteristics with the international migration literature, because they search for the bestexpected income and they are looking for a social network that could help them achieve this goal. An undocumented immigrant is a migrant who does not possess a valid immigration document, because the migrant either entered the country illegally, stayed longer than the temporary visa permitted, or violated the terms of their admission. The migrant is initially considered an international migrant, but after living in the country, the migrant behaves like an internal migrant also moving around without much restriction, looking for the place where they can get the best conditions and find safety. The migrant is inclined to blend in and try not to be spotted by or get attention from the authorities.

The aim of this chapter is to thoroughly test the determinants of undocumented immigration, based on the theory of economic incentives that attract and costs that decrease the motives of migrants to move to a state. This chapter exploits the differences between wages, incomes, and costs of consumption as attractors and deterrents for undocumented immigrants. The study also looks if undocumented immigrants take jobs from low-skilled native workers or if there is a separate underground labor demand that hires unauthorized immigrants. Firms will not pay high salaries because an undocumented immigrant is not legally authorized to work. The existence of a social network will help the immigrant find a job quickly and sanctuary cities, as argued by Cebula (2016a), provide an environment that decreases the sense of risk for the immigrant and allows him to progress faster.

This study improves the literature because it can provide evidence of changes in immigration and the relevant features that attract workers to sanctuary cities. The 
Juan Tomás Sayago-Gómez Chapter 3. Determinants of Undocumented Immigrants' Choice 34

possibility of understanding the dynamic and spatial spillovers from variables on the settlement of undocumented immigrants can provide support to strengthen the discussion about laws and immigration. It will highlight the changes through time and on which areas to focus regarding labor market controls. Our approach to the job market improves our knowledge about what attract immigrants. This analysis also improves on the literature related to the determinants of the location of undocumented immigrants because it considers variations over time to be relevant and this can improve the policy implications and the discussion about immigration laws in Congress. By arguying that policies may disperse undocumented immigrants to states where they were not present before.

The results from this study show that income expectations attract workers and costs deter them. The social network is relevant; however, the surge of sanctuary cities have reinforced their effect. Workers will move to places that have a better social environment. Spatial spillovers affect the migrant's decisions and could be relevant to explain further migrational movements.

This chapter is composed of six sections including this introduction, Section 3.1 reviews the literature related to undocumented immigration. Section 3.2 describes the data used in this study, and Section 3.3 presents the methodology used. Section 3.4 explains the results and Section 3.5 presents the main conclusions.

\subsection{Migration theory}

The literature related to undocumented migration is fairly recent and rapidly growing. It initially focused on the theoretical background and the factors that interact to affect the decisions of the agents. The second branch of research focused on proposing different methods to estimate the number of undocumented immigrants. Further devel- 
Juan Tomás Sayago-Gómez Chapter 3. Determinants of Undocumented Immigrants' Choice 35

opments allowed for the third branch of research that focused on empirical studies that would look at the determinants of undocumented immigration, the effect of different policies and outcomes on the labor market from undocumented immigration.

The theoretical developments began with the model proposed by Ethier (1986). Ethier proposes a model that extends Harris-Todaro's framework to consider unauthorized immigration, border, and internal enforcement. The model is an extension of Harris-Todaro, based on a disequilibrium in incomes that creates the stimulus to move(Harris and Todaro, 1970; Ethier, 1986). The model allows for a mix of policy that considers border enforcement and internal enforcement. Ethier's model was extended by Bond and Chen (1987), evaluating the optimal level of domestic enforcement. They find that the optimal level of enforcement and the enforcement costs make the enforcement policy less efficient. Djajic (1987) analyzes the problem focusing on the mechanisms that create the stimulus to move from the source country. Djajic (1987) concentrates on immigration policies and its role in the mechanism that affects the labor market. According to Djajic the mechanism is transferred from one country to another. Further theoretical developments provide a more complex structure, Bandyopadhyay and Bandyopadhyay (1998) propose a three-sector general equilibrium model of the source country, evaluating supply-side determinants. Liberalization of the agricultural sector spurs population movements, and liberalization of the high-tech sector deters migration.

Recent studies proposed policy extensions that affect undocumented immigrants' decisions. Hillman and Weiss (1999) propose a model that considers the possibility that the median voter allows the immigrants to stay as workers in specific sectors. Additionally Woodland and Yoshida (2006) extend Ethier's one country model into a two-country model. The authors consider two cases of capital mobility and border and internal enforcement. Another extension included in the model by Woodland and Yoshida (2006) is the relaxation of the risk neutrality assumption and considers differ- 
Juan Tomás Sayago-Gómez Chapter 3. Determinants of Undocumented Immigrants' Choice 36

ent attitudes towards risk and probability of getting caught. Gaytn-Fregoso and Lahiri (2000) analyze the effect of foreign aid on undocumented immigration and evaluate the effect of income repatriation and how the aid may increase immigration.

More recent approaches by Djajic and Michael (2014) consider the effect of cooperation between countries and the effect on immigration. Bandyopadhyay and Pinto (2017) set up a model that examines centralized and decentralized enforcement of immigration in a spatial context. The authors find that internal enforcement is over-provided and border enforcement and local goods under-provided. The authors extend the model to make the number of unauthorized immigrants endogenous and consider an alternate spatial structure that separates border and interior regions in the host country.

Another part of the research on undocumented immigrants has focused on measuring the number of undocumented immigrants. This research concentrates mainly on estimating the number of immigrants using one of two methods: The residual method and the Multiple Indicators Multiple Causes (MIMIC) model (Hanson, 2006; Passel, 2007; Passel and Cohn, 2011; Eichler, 2010; Buehn and Eichler, 2013; Warren and Warren, 2013). These models have created most of the estimates, and they include variations to increase accuracy. These models have provided estimates for yearly and monthly observations for the United States as a whole, as well as the individual states.

Empirical research has tried to unravel the determinants of the undocumented migration settlement patterns, including the effects of different state policies. Hanson and Spilimbergo (1999) examine the effect of changes in Mexican real wages on the apprehension of undocumented immigrants. They find that the purchasing power of wages in Mexico is the factor that drives Mexicans to migrate. A large devaluation of the Mexican peso also increases the number of apprehensions by the border patrol. Hanson and Spilimbergo (2001) conclude that border enforcement falls following positive shocks to sectors that depend on undocumented labor. Furthermore, they find a 
Juan Tomás Sayago-Gómez Chapter 3. Determinants of Undocumented Immigrants' Choice 37

negative relationship between border enforcement and the lag of changes in the relative price in apparel, fruits and vegetables, and livestock industries. Their results suggest that authorities loosen up on border enforcement in certain periods.

Studies on the determinants of undocumented immigrants have used a cross-sections of states and tested for the effect of different types of policies (Cebula et al., 2013; Amuedo-Dorantes and Sparber, 2014; Amuedo-Dorantes and Bansak, 2014; AmuedoDorantes and Pozo, 2014; Nair-Reichert, 2014; Cebula and Nair-Reichert, 2015; Cebula, 2016a,b). Chiswick (1988), Hanson (2006), and Hanson (2009) analyze the policies regarding undocumented immigrants as the source of low-skilled workers, and analyze the impact undocumented immigrants have on the economy and highlight certain issues related to the different types of enforcement against undocumented immigration. Hanson and McIntosh (2007) find evidence of existing networks as a relevant determinant of Mexican migration because the migrants will try to find locations where people they know reside. A network of friends and known persons is pertinent to the decision of where to live because it eases the job search and housing search (Hanson and McIntosh, 2007). Cebula et al. (2013) identify determinants of the settlement patterns of undocumented immigrants within the United States. Their results point towards states that border the Atlantic Ocean, Pacific Ocean, or the Gulf of Mexico. Cebula et al. (2013) also find a positive relationship between states with higher median family income, warmer average January temperatures, higher share of Hispanic population, and higher values of economic freedom, and a negative relationship with states having higher cost of living. Nair-Reichert (2014) extends the analysis to consider the real minimum wage and the share of Gross Domestic Product in different sectors.

Studies related to policies and enforcement have found mixed evidence. Cebula and Nair-Reichert (2015) explore the effect of policies favorable to access to education an undocumented immigrants in the State. Cebula et al. (2014) evaluate the attracting effect of unions for undocumented immigrants and find a negative relationship. This 
Juan Tomás Sayago-Gómez Chapter 3. Determinants of Undocumented Immigrants' Choice 38

negative relationship could be explained by a union-aversion for undocumented immigrants. Amuedo-Dorantes and Sparber (2014) find evidence that state-level policies to grant in-state tuition for undocumented immigrants are associated with higher tuition and fees, as well as, lower enrollment rates. Amuedo-Dorantes and Bansak (2014) evaluate the effect of E-Verify mandates on the employment, e-verify is a program to prevent undocumented immigrants from obtaining employment illegally in the United States, and wages of unauthorized immigrants. They conclude that employment of undocumented immigrants falls and the hourly wages of native-born male employees increases. Amuedo-Dorantes and Pozo (2014) analyze the effect of policies that increase enforcement, such as Operation Streamline (an example of border enforcement by the federal government) and state-level omnibus immigration laws (policies of interior enforcement by state governments). They find mixed evidence of the efficiency of the policies.

Cebula (2016b) used a panel data model to evaluate the impact of economic freedom on the settlement patterns of undocumented immigrants. The study also uses other measures of quality of life. They also consider cost of living and the expectations of costs. While high income might attract immigrants, the high costs will deter their migration(Cebula, 2016a,b). Cebula (2016a) finds a positive relationship between the presence of sanctuary cities and the location choice of undocumented immigrants.

\subsection{Data description}

This empirical study has three main data sources. Data on undocumented immigration come from estimates by Warren and Warren (2013). These data are estimated using the residual method, and the population by state from the CENSUS. Data on legal migration are published by the United States Department of Homeland Security (DHS). Data on state economic conditions are published by the Bureau of Economic 
Juan Tomás Sayago-Gómez Chapter 3. Determinants of Undocumented Immigrants' Choice 39

Analysis(BEA). Data on sanctuary cities are created from the information published by the Ohio Jobs \& Justice PAC (2017). I set up a data panel by state for the United States from 2005 to 2010 . This panel has yearly observations and the panel includes all continental states, excludes the District of Columbia.

The dependent variable is the share of undocumented population, it is measured by percentage of population that is considered undocumented immigrants. The calculation used is equation (3.1). Estimating the number of undocumented immigrants has been a big research hurdle, because it is not something that can be measured directly. As explained in the previous section, there are two main methods used to estimate the number of unauthorized immigrants. The Multiple Indicators Multiple Causes model (MIMIC) estimates the number of unauthorized immigrants as a latent variable (Eichler, 2010; Buehn and Eichler, 2013). The problem of using this method is that you normally use variables related to the latent variable to estimate it and then you cannot use the same variables to estimate econometric models. The other method is the residual method. This method uses the estimates of immigrant population or population born in any country other than the United States and subtracts the total number of legal immigrants in the state (Hanson, 2006; Passel, 2007; Passel and Cohn, 2011; Warren and Warren, 2013). This methodology set up by Passel (2007) uses estimates of foreign population $(S)$ from the Bureau of the Census and then subtracts the number of total allowed immigrants $(L)$ that is registered by year from the Department of Homeland Security. The result from the equation is the undocumented immigrants $(U n d o c)$ used in equation (3.2).

$$
\begin{gathered}
\text { undocrate }=\frac{\text { Undoc }_{t, i}}{\text { Population }_{t, i}} \\
\text { Undoc }=S-L
\end{gathered}
$$


Juan Tomás Sayago-Gómez Chapter 3. Determinants of Undocumented Immigrants' Choice 40

Recently Warren and Warren (2013) developed an extension of the residual method used by Passel (2007). The estimation method proposed by Warren and Warren (2013) provides a solution to all the issues in the residual method defined by Hanson (2006). Their method extends the residual method to adjust and control by Emigration (Emig), Removal by the DHS $(R E M)$, Adjustment to Lawful Status $(A d j)$ or Death $(D)$ (See equation (3.3)). According to Warren and Warren (2013) their results differ from Passel (2007) in the estimates for States with smaller populations, long term trends, and estimates derived for arrival and departures. It is the method used in this study because of the accuracy for smaller states.

$$
U n d o c=S-L-(E m i g+R e m+A d j+D)
$$

Table 3.1: Descriptive statistics.

\begin{tabular}{|c|c|c|c|c|}
\hline Variable & Mean & St. Dev. & Min & Max \\
\hline RGDPPC & $46,158.850$ & $8,230.845$ & 30,813 & 70,096 \\
\hline Ln(RGDPPC) & 10.725 & 0.173 & 10.336 & 11.158 \\
\hline RWages & $127,409,020$ & $147,221,609$ & $9,335,747$ & $842,860,549$ \\
\hline Ln(RWages) & 13.563 & 1.053 & 11.521 & 15.959 \\
\hline PCost & $31,567.530$ & $4,220.307$ & 22,677 & 42,987 \\
\hline $\operatorname{Ln}($ PCost $)$ & 5.774 & 0.129 & 5.516 & 6.071 \\
\hline Sanctuary & 2.302 & 5.873 & 0 & 36 \\
\hline Dummysanc & 0.420 & 0.494 & 0 & 1 \\
\hline PopSanctuary & $1,059,259$ & $2,413,482$ & 0 & $17,289,843$ \\
\hline Ln(PopSanctuary) & 2.533 & 3.020 & 0.000 & 7.240 \\
\hline Undoc & 244,371 & 498,802 & 196 & $3,131,311$ \\
\hline Population & $6,249,193$ & $6,697,522$ & 514,157 & $37,332,685$ \\
\hline Undocrate & 0.026 & 0.020 & 0.0003 & 0.086 \\
\hline $\operatorname{LImmig}_{t-10}$ & $15,526.170$ & $33,278.540$ & 159 & 217,753 \\
\hline Population $_{t-10} 0$ & $5,663,188$ & $6,003,104$ & 485,160 & $33,987,977$ \\
\hline LImmigrate $_{t-10}$ & 0.174 & 0.150 & 0.021 & 0.829 \\
\hline
\end{tabular}

The share of undocumented immigrants for year 2010 is presented in Figure 3.1. It shows concentration of more unauthorized immigrants in the border areas and states 
Figure 3.1: Share of undocumented immigrants in 2010. Source: Warren and Warren (2013)

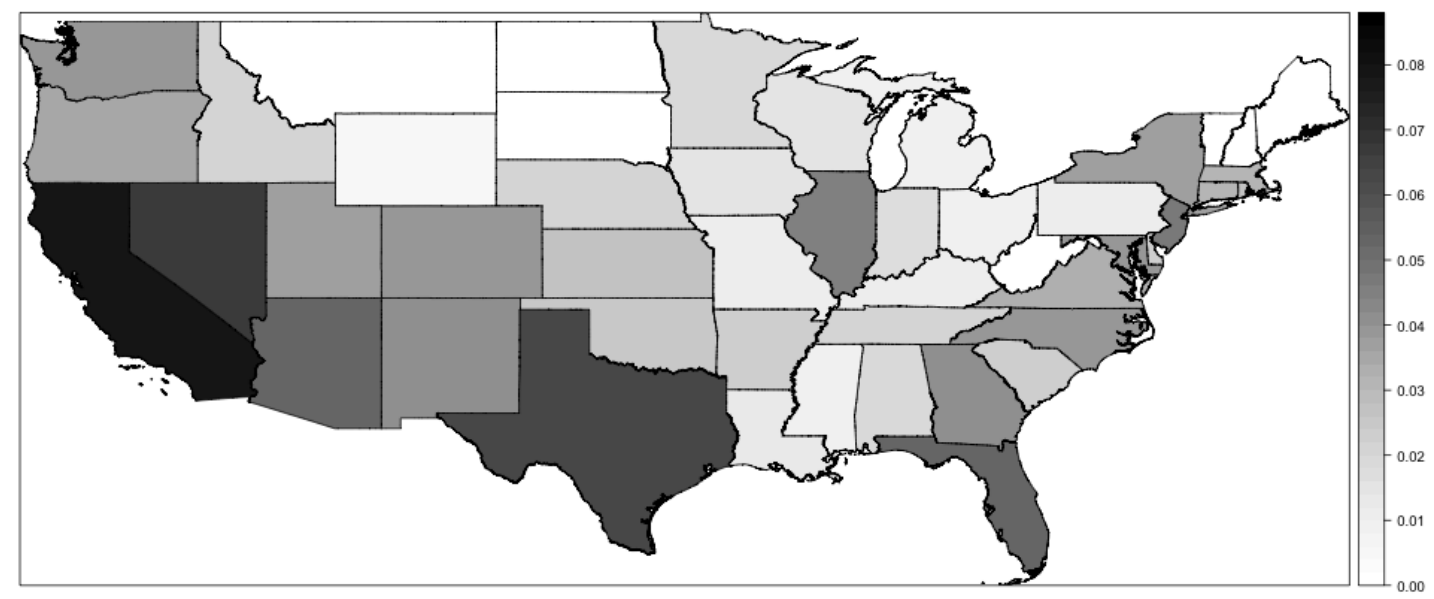

with larger cities. It is important to notice the importance gained by some states in the Midwest, Northwest and East of the United States.

Table 3.1 shows that the mean undocumented population for a state is 244,371 with a standard deviation of 498,802 . The share of undocumented immigration in a state's population was 2.6 percent, with a standard deviation of 2 percent.

The control variables used in the analysis are: Real Gross Domestic Product per Capita $(R G D P P C)$ by state, Real Wages per Capita (RWages) by state, Personal Consumption Expenditures (PCost), Legal immigrants by state 10 years before $\left(\right.$ LImmig $\left._{t-10}\right)$, and the Sanctuary variables. The economic variables of GDPPC, RWages, and PCost are available from the Bureau of Economic Analysis (2017).

The sanctuary variables are calculated and used three ways. The first one is a dummy that takes the value for the state and year of one (1) when there at least one sanctuary city in the state. The second one takes a value of the number of cities that have been declared sanctuary city, following the approach by Cebula (2016a). The last 
Juan Tomás Sayago-Gómez Chapter 3. Determinants of Undocumented Immigrants' Choice 42

one measures the population for the declared sanctuary cities. This measurement follows a similar approach as the network possibilities for the undocumented immigrants. I calculate the natural logarithm for this variable ${ }^{1}$. The descriptive statistics for all variables and their logs when appropriate are included in Table 3.1.

\subsection{Estimation strategy}

The model to find the determinants of the proportion of the population who are undocumented migration will include the control variables used in the literature. These variables include economic variables, such as income and wage attractors and cost variables. Economic variables encourage and discourage immigration for a potential destination. The model also includes variables related to previous migration to account for possible networks, as well as, Sanctuary variables for the potential destination (see equation (3.4)). The model is a panel data model that includes observations for the 48 states $^{2}$ and for the period from 2005 to $2010(N=288)$. The model is:

$$
\begin{aligned}
\text { Undocrate }_{t, i} & =\beta_{0}+\beta_{E} \text { Economic }_{t, i}+\beta_{L} L I M M I G_{t-10, i} \\
& +\beta_{S} \text { Sanctuary }_{i t}+u_{i t}
\end{aligned}
$$

where Undocrate $_{t, i}$ is the share of population that is undocumented immigrant in the state $i$ and for the year $t$. The variables included for economic attractiveness are $R G D P P C$ and RWages. PCost is used as a proxy for costs, whileLImmig $g_{t-10}$ is a proxy for a network of previous migrants. The variables used for sanctuary are: Sanctuary, Dummysanc, Ln(PopSanctuary). Previous literature has highlighted that there are spatial spillover effects in migration (Lozano-Gracia et al., 2010; LeSage and Thomas-Agnan, 2015) because the migration flow is affected by the different changes

\footnotetext{
${ }^{1}$ When PopSanctuary equals 0 , I assign a value of 1 so the natural log is defined.

${ }^{2}$ Continental states excluding District Columbia.
} 
Juan Tomás Sayago-Gómez Chapter 3. Determinants of Undocumented Immigrants' Choice 43

and attractiveness of neighbors that could be the next step in migration if the migrant cannot find work quickly. This hypothesis is consistent with the use of a spatial autoregressive model.

The spatial version of the previous data panel model is a spatial panel model. This model, as explained by Elhorst (2014), "is an extension of the general nesting model from cross section ... to a panel of N observations for T time periods" (Elhorst, 2014, p. 37). The model is presented in equations (3.5) and (3.6)

$$
\begin{gathered}
Y_{t, i}=\alpha \iota_{N}+\rho W Y_{t, i}+X_{t, i} \beta+W X_{t, i} \theta+u_{t, i} \\
u_{t, i}=\lambda W u_{t, i}+\epsilon_{t, i}
\end{gathered}
$$

To account for spatial and temporal heterogeneity, Elhorst (2014) suggests including intercepts $\mu$ and $\xi$ as the effects estimates, just as in a standard panel data model (Elhorst, 2014). Elhorst (2014) also discusses estimating the spatial panel model with fixed and random effects, as well as estimating different spatial models. According to Elhorst (2014) "the Hausman specification test might be used" to define which model (fixed effects vs random effects) is the most appropriate. Also a Likelihood Ratio test can be used to identify the model should include fixed and random effects are necessary as part of better fitted model (Elhorst, 2014).

A very important part of the structure describing the spatial model is the Weight Matrix $(W)$. This $(W)$ matrix is populated by zeroes (0) and ones (1), defines who is a neighbor to whom, and then they are weighted by the total sum of the row to provide a standardized weighted value. The ones are assigned to designate neighbors. By construction, this matrix should have only zeros on the diagonal, because you cannot be a neighbor to yourself. There are different methods for building the $W$ matrix, including the queen contiguity matrix, which is used for this analysis. According to this method, neighbor is one who shares either a boundary or a corner (Anselin et al., 2008; LeSage 
Juan Tomás Sayago-Gómez Chapter 3. Determinants of Undocumented Immigrants' Choice 44

and Pace, 2010). Equations 3.7 and 3.8, which incorporate fixed effects in a spatial panel model, will be used for the analysis.

$$
\begin{gathered}
Y_{t, i}=\alpha \iota_{N}+\rho W Y_{t, i}+X_{t, i} \beta+W X_{t, i} \theta+\mu+\xi_{T} \iota_{N}+u_{t, i} \\
u_{t, i}=\lambda W u_{t, i}+\epsilon_{t, i}
\end{gathered}
$$

There are different types of spatial panel models: The Spatial Autoregressive model $(S A R)$ includes the spatial lag of the dependent variable $(\rho \neq 0)$ and makes the assumption that the lag of the error and vector of independent variables coefficients are equal to zero $(\theta=\lambda=0)$, the SAR model is presented in equation (3.9). This model is consistent with the hypothesis that migrants select states where they can find better conditions and also have good neighbors to migrate to if needed.

$$
Y_{t, i}=\alpha \iota_{N}+\rho W Y_{t, i}+X_{t, i} \beta+\mu+\xi_{T} \iota_{N}+u_{t, i}
$$

The Spatial Error Model $(S E M)$ includes the spatial lag of the error $(\lambda \neq 0)$ and makes the assumption that the lag of the dependent variable and independent variables coefficients are equal to zero $(\theta=\rho=0)$, the SEM model is presented in equations (3.10) and (3.11). This model is used mostly if there is missing information that cannot be captured by other variables and this missing information is spatially autocorrelated.

$$
\begin{gathered}
Y_{t, i}=\alpha \iota_{N}+X_{t, i} \beta+\mu+\xi_{T} \iota_{N}+u_{t, i} \\
u_{t, i}=\lambda W u_{t, i}+\epsilon_{t, i}
\end{gathered}
$$

The SLX Model includes the spatial lag of the independent variables $(\theta \neq 0)$ and makes the assumption that the spatial lags of the dependent variable and independent 
Juan Tomás Sayago-Gómez Chapter 3. Determinants of Undocumented Immigrants' Choice 45

variables coefficients are equal to zero $(\lambda=\rho=0)$, the SLX model is presented in equation (3.12). This model is used mostly if values of explanatory vvariable in one region can explain the value of dependent variable in neighboring region.

$$
Y_{t, i}=\alpha \iota_{N}+X_{t, i} \beta+W X_{t, i} \theta+\mu+\xi_{T} \iota_{N}+u_{t, i}
$$

Other specifications considered in the literature are the Spatial Autoregressive Autoregressive model $(S A R A R)$. The SARAR model includes the spatial lag of the dependent variable and the error $(\rho \neq 0$ and $\lambda \neq 0)$, but the coefficients for the spatial lags of the independent variables is zero $(\theta=0)$. The Spatial Durbin Model (SDM) includes a spatial lag of the dependent variable and the spatial lag of the independent variables $(\rho \neq 0$ and $\theta \neq 0)$. The Spatial Error Durbin Model (SDEM) includes the spatial lag of the error and the spatial lag of the independent variables.

To decide which model best fits the analysis better, you can choose according to a theoretical hypothesis, e.g. if you consider that there is a specific theory for your model that justifies the inclusion of one type of model or another. Additionally Anselin et al. (2008) proposes an extension of the Lagrange Multiplier $(L M)$ tests proposed by Anselin et al. (1996) to identify which is the better fitting model. These tests and their robust versions are used to define which is the better model (Elhorst, 2014). However, these tests only work for SAR, SEM and SARMA

After the model is selected and estimated the interpretation of the model is key since there is a non-linearity when the dependent variable is part of the model. LeSage and Pace (2010) and Elhorst (2014) explain that the results from SAR and SDM models cannot be explained directly because of the endogeneity in the dependent variable because the independent variables affect the dependent variable, but also since the dependent variable of the neighbors $(W Y)$, it means that their independent variables will 
Juan Tomás Sayago-Gómez Chapter 3. Determinants of Undocumented Immigrants' Choice 46

also affect the dependent variable. This process is called the global spatial spillover. LeSage and Pace (2010) proposed a method to estimate the impact of the variables that interact in the model via the spatial lag of the dependent variable $(W Y)$. Elhorst (2014) explains this methodology is extended to panel data models and how different models require different estimations to observe the effect of the independent variables on the dependent variable. The impact analysis will measure the impact of the independent variables directly on the unit and indirectly by way of the neighbor. These impacts are the direct effects, the indirect effects, and total effects. These effects are explained as the effects of the state on itself (same state), the effect from the others (other states), and the total effect.

\section{$3.4 \quad$ Results}

The analysis is applied to three models, these models differentiate by the way the Sanctuary variable is measured. The models use each measurement of Sanctuary as they could be attractors for undocumented immigrants. The dummy variable tests whether the existence is an attractor or not, the number of cities considers that the attractors is the number of cities that are declared as sanctuaries and the population of sanctuary cities divides the effect from the existence into a pseudo network effect that is related to the population in the sanctuary cities in the state. The analysis will first choose the type of model that fits the data better between the models discussed in the previous section.

The test to decide if the spatial panel model should include fixed effects or be pooled is the Likelihood Ratio (LR) test. The results of the LR test in Table 3.2 show that the fixed effects should be included in the model. This test compares the Likelihood ratios

of the two models with the fixed effects and the pooled model. The results in table 3.2 show the rejection of the null hypothesis to support evidence that they should be 
Juan Tomás Sayago-Gómez Chapter 3. Determinants of Undocumented Immigrants' Choice 47

included.

Table 3.2: Likelihood Ratio (LR) Test for the spatial panel models.

\begin{tabular}{lccc}
\hline \hline Model 1 & & & \\
\hline Test & Statistic & DF & p-value \\
Spatial fixed effects & 1367.6765 & 48 & 0.000 \\
Time-period fixed effects & 17.6313 & 6 & 0.007 \\
\hline \hline Model 2 & & & \\
\hline Test & Statistic & DF & p-value \\
Spatial fixed effects & 1367.2617 & 48 & 0.000 \\
Time-period fixed effects & 18.8377 & 6 & 0.004 \\
\hline \hline Model 3 & & & \\
\hline Test & Statistic & DF & p-value \\
Spatial fixed effects & 1375.7194 & 48 & 0.000 \\
Time-period fixed effects & 19.065 & 6 & 0.004 \\
\hline \hline
\end{tabular}

As explained in the previous section Lagrange Multiplier (LM) tests are used to decide which model fits the data better. The results from the LM tests are included in Table 3.3, the LM tests show that the spatial lag test and spatial error hypothesis is rejected in both, however the robust versions of the tests only reject the null hypothesis for the spatial lag model and not for the spatial error in all three models.

The spatial adjusted Hausman test will test the hypothesis if the random effects model and the fixed effect models are consistent or reject it. Table 3.4 presents results from the spatial Hausman test. The test rejects the null hypothesis in all three models, this result point towards using the fixed effects model.

Table 3.5 presents the results from the spatial panel models. The results show that the coefficient associated to the spatial lag of the dependent variable is positive and significant. The results are positive and significant for RGDPPC and RWages and negative but not significant for PCost. The Share of legal immigrants from ten years 
Juan Tomás Sayago-Gómez Chapter 3. Determinants of Undocumented Immigrants' Choice 48

Table 3.3: Lagrange Multiplier Tests (LM) for the specification of the spatial panel models.

\begin{tabular}{lcc}
\hline \hline Model1 & & \\
\hline Test & Statistic & p-value \\
LM test no spatial lag & 86.706 & 0.000 \\
robust LM test no spatial lag & 33.622 & 0.000 \\
LM test no spatial error & 55.321 & 0.000 \\
robust LM test no spatial error & 2.236 & 0.135 \\
\hline \hline Model2 & \multicolumn{3}{l}{} \\
\hline Test & 85.846 & 0.000 \\
LM test no spatial lag & 34.361 & 0.000 \\
robust LM test no spatial lag & 53.400 & 0.000 \\
LM test no spatial error & 1.914 & 0.167 \\
robust LM test no spatial error & \multicolumn{3}{l}{} \\
\hline \hline Model3 & Statistic & p-value \\
Test & 79.186 & 0.000 \\
LM test no spatial lag & 28.591 & 0.000 \\
robust LM test no spatial lag & 53.050 & 0.000 \\
LM test no spatial error & 2.455 & 0.117 \\
robust LM test no spatial error & \multicolumn{2}{l}{} \\
\hline \hline
\end{tabular}

Table 3.4: Hausman Test for the spatial panel models.

\begin{tabular}{cccc}
\hline \hline & Hausman & DF & p-value \\
\hline Model 1 & 22.8596 & 11 & 0.0185 \\
Model 2 & 24.1207 & 11 & 0.0122 \\
Model 3 & 27.8265 & 11 & 0.0034 \\
\hline \hline
\end{tabular}

before is positive and significant. The LR test and Wald test confirm that the models should be a SDM and include the lag of the independent variables. The spatial lag of the independent variable shows positive and significant result for RGPPC and negative and significant coefficients for Rwages and PCost. The coefficient associated to lag of the variable Immig $_{t-10}$ is negative, but insignificant.

All the sanctuary variables have positive coefficients, however it is significant only 
Juan Tomás Sayago-Gómez Chapter 3. Determinants of Undocumented Immigrants' Choice 49

for the Dummy for the presence of a Sanctuary city and the population in the sanctuary city. This result identifies a preference for larger cities because they have more immigrants and they have larger labor markets. The result also holds for the spatial lag of the sanctuary dummy and the population in Sanctuary cities.

Table 3.6 shows the estimates of the direct, indirect and total effects. There is a positive direct and indirect effect for GDPPC, this result could be explained by the perspective of migration and having into account future migration or the perception of states that have good socioeconomic conditions. However, the effect estimates for RWages are positive direct effect and negative indirect effect. Though this result seems puzzling, it could be associated with a stonger pull effect by the state that pays the highest salaries against its neighbors. Additionally, when the state has a neighbor with a high wage, it will affect negatively the neighbor and attract the immigrants to further migration. The both effects from PCost are both negative and significant, this variable is a proxy for cost of living and this variable and the spatial lag are viewed by the undocumented immigrants as variables that have a deterring effect.

Both effects estimates for Immig $_{t-10}$ are positive and significant, this result is explained by the social network effect and the possible spreading of immigrants to neighboring states. The effect estimates for the sanctuary variables are positive and significant for the Dummysanc and the logarithm of the population in sanctuary cities (Ln(PopSanctuary)), but they are not significant for the number of cities (Sanctuary). The sanctuary dummy variable approach is significant and positive because it means that the existence of at least one Sanctuary city makes the state attractive for the undocumented immigrant population and also the neighboring states. However, this analysis cannot clearly distinguish between undocumented immigration coming directly to a state that neighbors one with at least one sanctuary city and the undocumented immigrant moving to the state with a sanctuary city and then proceeding towards the neighboring state. 
Juan Tomás Sayago-Gómez Chapter 3. Determinants of Undocumented Immigrants' Choice 50

Table 3.5: Results for the spatial autoregressive panel models with fixed effects of the Share of undocumented immigrants of all population. The values in parenthesis are t-statistics.

\begin{tabular}{|c|c|c|c|}
\hline Variable & Model 1 & Model 2 & Model 3 \\
\hline Ln(RGDPPC) & $\begin{array}{c}0.014^{* * *} \\
(3.113)\end{array}$ & $\begin{array}{c}0.014^{* * *} \\
(3.169)\end{array}$ & $\begin{array}{c}0.014^{* * *} \\
(3.066)\end{array}$ \\
\hline Ln(RWages) & $\begin{array}{c}0.003^{* * *} \\
(3.113)\end{array}$ & $\begin{array}{c}0.003^{* * *} \\
(3.169)\end{array}$ & $\begin{array}{c}0.004^{* * *} \\
(3.066)\end{array}$ \\
\hline $\operatorname{Ln}($ PCost $)$ & $\begin{array}{c}-0.012 \\
(-1.388)\end{array}$ & $\begin{array}{c}-0.012 \\
(-1.379)\end{array}$ & $\begin{array}{c}-0.013 \\
(-1.487)\end{array}$ \\
\hline $\operatorname{LImmig}_{t-10}$ & $\begin{array}{l}0.067^{* * *} \\
(12.647)\end{array}$ & $\begin{array}{l}0.067^{* * *} \\
(12.574)\end{array}$ & $\begin{array}{l}0.067^{* * *} \\
(12.037)\end{array}$ \\
\hline Dummysanc & $\begin{array}{c}0.004^{* * *} \\
(3.769)\end{array}$ & & \\
\hline Ln(PopSanctuary) & & $\begin{array}{c}0.001^{* * *} \\
(3.884)\end{array}$ & \\
\hline Sanctuary & & & $\begin{array}{c}0.000104 \\
(1.144)\end{array}$ \\
\hline $\mathrm{W}^{*} \operatorname{Ln}(\mathrm{RGDPPC})$ & $\begin{array}{c}0.029^{* * *} \\
(2.901)\end{array}$ & $\begin{array}{c}0.030^{* * *} \\
(2.970)\end{array}$ & $\begin{array}{c}0.030^{* * *} \\
(2.721)\end{array}$ \\
\hline $\mathrm{W}^{*} \operatorname{Ln}($ RWages $)$ & $\begin{array}{c}-0.003^{* * *} \\
(-3.178)\end{array}$ & $\begin{array}{c}-0.003^{* * *} \\
(-3.079)\end{array}$ & $\begin{array}{c}-0.003^{* *} \\
(-2.497)\end{array}$ \\
\hline $\mathrm{W}^{*} \operatorname{Ln}(\mathrm{PCost})$ & $\begin{array}{c}-0.056^{* * *} \\
(-4.86)\end{array}$ & $\begin{array}{c}-0.057^{* * *} \\
(-4.954)\end{array}$ & $\begin{array}{c}-0.051^{* * *} \\
(-4.324)\end{array}$ \\
\hline $\mathrm{W}^{*} \mathrm{LImmig}_{t-10}$ & $\begin{array}{c}-0.015 \\
(-1.049)\end{array}$ & $\begin{array}{c}-0.013 \\
(-1.177)\end{array}$ & $\begin{array}{c}-0.012 \\
(-1.032)\end{array}$ \\
\hline $\mathrm{W}^{*}$ Dummysanc & $\begin{array}{l}0.006^{* *} \\
(2.263)\end{array}$ & & \\
\hline $\mathrm{W}^{*} \operatorname{Ln}($ PopSanctuary) & & $\begin{array}{l}0.001^{* *} \\
(2.365)\end{array}$ & \\
\hline $\mathrm{W}^{*}$ Sanctuary & & & $\begin{array}{c}0.000 \\
(1.600)\end{array}$ \\
\hline$W^{*}$ dep.var. & $\begin{array}{c}0.548^{* * *} \\
(9.988)\end{array}$ & $\begin{array}{c}0.545^{* * *} \\
(9.897)\end{array}$ & $\begin{array}{l}0.562^{* * *} \\
(10.336)\end{array}$ \\
\hline Wald test & 11.21 & 13.22 & 11.282 \\
\hline p-value & 0.047 & 0.021 & 0.046 \\
\hline LR test & 13.425 & 12.943 & 10.988 \\
\hline p-value & 0.02 & 0.024 & 0.052 \\
\hline
\end{tabular}


Juan Tomás Sayago-Gómez Chapter 3. Determinants of Undocumented Immigrants' Choice 51

The natural logarithm of the population in Sanctuary cities makes follows a rationality similar to the presence of social network or what is called the gravity approach. The gravity approach explains that large populations attract more migrants Greenwood (1993). The undocumented immigrants perceive that the population in sanctuary cities as an attractive labor market, because it provide a safe environment and they are able to blend in.

Table 3.6: Effect estimates for the spatial panel models with fixed effects of the Share of undocumented immigrants of all population.

\begin{tabular}{|c|c|c|c|c|c|c|}
\hline \multicolumn{7}{|l|}{ Model1 } \\
\hline Variable & direct & t-stat & indirect & t-stat & total & t-stat \\
\hline Ln(RGDPPC) & $0.021^{* * *}$ & 3.579 & $0.076^{* * *}$ & 3.183 & $0.097^{* * *}$ & 3.449 \\
\hline Ln(RWages) & $0.003^{* * *}$ & 3.60 & $-0.003^{*}$ & -1.764 & -0.001 & -0.258 \\
\hline $\operatorname{Ln}($ PCost $)$ & $-0.023^{* * *}$ & -2.746 & $-0.129^{* * *}$ & -6.146 & $-0.152^{* * *}$ & -6.691 \\
\hline $\operatorname{LImmig}_{t-10}$ & $0.072^{* * *}$ & 12.176 & $0.052^{* * *}$ & 2.696 & $0.123^{* * *}$ & 5.538 \\
\hline Dummysanc & $0.006^{* * *}$ & 4.272 & $0.017^{* * *}$ & 3.116 & $0.023^{* * *}$ & 3.618 \\
\hline \multicolumn{7}{|l|}{ Model 2} \\
\hline Variable & direct & t-stat & indirect & t-stat & total & t-stat \\
\hline Ln(RGDPPC) & $0.021^{* * *}$ & 3.759 & $0.077^{* * *}$ & 3.358 & $0.097^{* * *}$ & 3.651 \\
\hline Ln(RWages) & $0.003^{* * *}$ & 3.396 & $-0.003^{*}$ & -1.741 & -0.001 & -0.309 \\
\hline $\operatorname{Ln}($ PCost $)$ & $-0.023^{* * *}$ & -2.658 & $-0.13^{* * *}$ & -6.218 & $-0.152^{* * *}$ & -6.746 \\
\hline $\operatorname{LImmig}_{t-10}$ & $0.071^{* * *}$ & 12.42 & $0.047^{* *}$ & 2.461 & $0.118^{* * *}$ & 5.327 \\
\hline Ln(PopSanctuary) & $0.001^{* * *}$ & 4.205 & $0.003^{* * *}$ & 3.191 & $0.004^{* * *}$ & 3.675 \\
\hline \multicolumn{7}{|l|}{ Model3 } \\
\hline Variable & direct & t-stat & indirect & t-stat & total & t-stat \\
\hline Ln(RGDPPC) & $0.021^{* * *}$ & 3.665 & $0.081^{* * *}$ & 3.146 & $0.103^{* * *}$ & 3.404 \\
\hline Ln(RWages) & $0.004^{* * *}$ & 5.021 & -0.002 & -0.618 & 0.002 & 0.884 \\
\hline $\operatorname{Ln}($ PCost $)$ & $-0.024^{* * *}$ & -2.825 & $-0.124^{* * *}$ & -5.826 & $-0.148^{* * *}$ & -6.354 \\
\hline $\operatorname{LImmig}_{t-10}$ & $0.072^{* * *}$ & 11.326 & $0.054^{* * *}$ & 2.241 & $0.126^{* * *}$ & 4.554 \\
\hline Sanctuary & 0.00 & 1.434 & 0.001 & 1.747 & 0.001 & 1.781 \\
\hline
\end{tabular}


Juan Tomás Sayago-Gómez Chapter 3. Determinants of Undocumented Immigrants' Choice 52

\subsection{Conclusions}

This chapter attempts to test the determinants for the location of undocumented immigrants. I set up a spatial panel model for the states of the United States for the period from 2005 to 2010 . The results from the model highlight the economic variables and networks used in previous research. The effect from sanctuary cities is proportional to the population size that lives in the city rather than to the number of cities. The sanctuary dummy provides a support for the hypothesis that having at least one sanctuary city is attractive for undocumented immigrants.

The spatial model results support the idea of a possible next step migration in economic terms, sanctuary, and existing networks. The interaction between the direct and indirect effects of wages is puzzling because it does not support the high wage neighbor hypothesis. But it could be explained by the perception based on the GDP and proxy of availability of work rather than the possibility of receiving a higher wage. 


\section{Chapter 4}

\section{Changes in Poverty \\ Measurements and Forced}

\section{Migration: The Case of Colombia}

Migration is defined as the movement of population from one place to another. This change of residence usually occurs in response to a disequilibrium observed between two regions (Sjaastad, 1962; Harris and Todaro, 1970). People usually move to another place in response to differences in wages or incomes between regions, or some other factor that affects welfare. However, Colombia has experienced an internal conflict for fifty years. In the 1990s, armed groups forced people to migrate as part of a strategy to gain dominance over specific territories and control the population located in them. The displaced population lose most of their belongings when they flee to a new place in order to survive (Ibáñez and Moya, 2010). The purpose of this chapter is twofold. First, I decompose the change in poverty in Colombian municipalities for the period of 1993 to 2005 to understand what improvements happened and where. Second, I explore whether forced migration created the structural change that affected measurements of poverty and made them fall, despite the fact that forced displacement took away all the physical capital that displaced families use to hold (Ibáñez and Moya, 2010). 
The first Millennium Development Goal set in the Millennium Summit of the United Nations in 2000 is for developing countries to reduce extreme poverty by half. This goal set by the United Nations highlights the relevance of poverty in developing countries. This chapter explores how poverty changed, and the components that improved. What part of this change in the measurement of poverty is related to forced displacement? I highlight the importance of a thorough comprehension of the poverty changes and their impact on public policy. To explore the changes, I propose a structural decomposition of the poverty change using Shift-Share Analysis to evaluate the changes in regions and dimensions. This also helps identify changes caused by using different measures of poverty.

Shift-Share Analysis is a tool used in regional science to separate improvements of employment or value added in different sectors and regions. It emphasizes which sectors have developed more thoroughly and which are slower, while at the same time highlighting what locations are making greater changes. Shift-Share Analysis is also used to analyze structural changes in the composition of labor markets or changes in the evolution of fertility rates, age composition of migration trends, and population changes (Bonet-Morón, 1999; Franklin and Plane, 2004; Franklin, 2012; Plane, 1987). Such analysis focuses on transformations towards new dynamics of development and change.

This analysis explores changes and improvements in the components of poverty for municipalities for the period 1993-2005. It is interesting that the municipalities that improved the most are those municipalities that received more forced displaced population. The municipalities that decreased poverty in Unmet Basic Needs (UBN), but did not increase the number of non-poor population are those municipalities that pushed out population. Additionally, due to the cost of poverty reductions, it is cheaper for institutions to expand access to public services in urban areas. The displaced people 
would gain access to urban amenities, but this does not compensate for the quality of living that the displaced population lost when they had to leave everything behind.

Previous research related to forced displacement by Sayago-Gómez (2012a) showed which municipalities received displaced population. According to my decomposition, these municipalities increased the size of their non-poor population. Additionally Sayago-Gómez (2012a) highlights which municipalities pushed out more population due to conflict. I show that some municipalities did not increase the number of nonpoor population, yet decreased poverty, and others increased the number of non-poor people at a slower rate, yet decreased poverty. This can happen if a sufficient number of the poor are pushed out. I estimate a spatial econometric model to test for the relevance of displacement for change in poverty. The spatial model accounts for spatial spillovers from the internal conflict on displacement (Sayago-Gómez, 2012a; LozanoGracia et al., 2010) due to the missing information related to the presence of armed groups and the probabilities of migrating in all directions.

The main findings in this chapter are twofold. First, I highlight which regions developed more and which regions are growing at a slower rate, which regions reduced poverty, and which components contributed more to poverty reduction. Second, I find that the poorest areas did not reduce the non-poor population. Third, I show that forced displacement affected the UBN measurements of poverty, because I find that the UBN poverty reductions were partly caused by the displacement and access to urban amenities. Fourth, the contrast between UBN and the Multidimensional Poverty Index (MPI) shows that these municipalities did not decrease in the poor population.

The remainder of the paper is organized as follows: Section 4.1 discusses recent studies related to forced displacement, poverty and their possible relationship in the literature. Section 4.2 examines the empirical methodology. Section 4.3 presents data and transformations to analyze the information. Section 4.4 provides results of the 
Shift-Share analysis and Section 4.5 looks at the regression results and the spatial model. Finally, Section 4.6 concludes the study with some closing remarks.

\subsection{Background literature}

This literature review is composed of three main issues. The first relates to decomposition applications for poverty and decompositions used in regional science. The second regards forced migration in Colombia and the research questions that have been answered and their contributions to the research of this paper. The third topic is the relationship between poverty and migration.

Poverty decompositions have been used to analyze changes in poverty changes and understand different effects of these changes. Datt and Ravallion (1992) proposed a method to separate the change in poverty into distribution-neutral growth and redistribution effects. While Huppi and Ravallion (1991) suggested a method to decompose changes over time into intra-sectoral effects and population shifts. Azevedo et al. (2013a) and Azevedo et al. (2013b) proposed decomposition of poverty and inequality changes. The decomposition of poverty of Colombian data was proposed by Pérez Pérez et al. (2015), who decompose the Multidimentional Poverty Index (MPI) into its dimensions to explore the changes between national measures and determine which dimensions are the bigger weaknesses in Colombian Poverty. However, the Multidimensional Poverty Index has only been estimated using the information from the 2005 Census.

The proposed method to decompose poverty has been used in regional science for many years to separate changes in employment and value added. Regional Science research uses Shift-Share Analysis to separate competitive and regional effects (Selting et al., 1992; Loveridge and Selting, 1998; Capello, 2007; Jackson and Haynes, 2009). 
Juan Tomás Sayago-Gómez Chapter 4. Poverty Changes and Forced Migration 57

And it has been used widely to analyze growth changes in states and regions of the United States (Selting et al., 1992; Loveridge and Selting, 1998). Additionally Nazara and Hewings (2004) proposed extensions to highlight different changes and other specifications of analytical regional conceptions, more explicitly the regional change in comparison to the region's neighbors.

This analysis has been extended to study changes in the population structure such as Plane (1987); Franklin and Plane (2004); Franklin (2012). Their analysis aimed to identify the pattern of variation and the groups that stray from the previous structure. Shift-Share has been applied to Colombian data to identify changes in value added that define the economic structure in the different regions (Bonet-Morón, 1999).

Research related to forced migration in Colombia has focused on the identification of the characteristics of migrants, the expulsion process, the consequences for quality of life, the destination choice, and the policies instituted by the government (Ibáñez, 2008). The article by Ibáñez and Moya (2010) addresses the economic consequences of displacement and how displaced population remain in poverty after the displacement process and the low rates of economic retrieval of their capital after displacement. The book by Ibáñez (2008) includes a thorough compilation of articles that address most of the issues related to forced displacement. The only article that addresses the consequences of the internal conflict on the economic and political institutions is the study by Cardenas et al. (2016). Cardenas et al. (2016) find a negative effect from internal conflict on the state capacity (or institutional strength) in Colombian municipalities.

Furthermore, previous research pointed out that displaced people are part of a spatial process (Lozano-Gracia et al., 2010; Sayago-Gómez, 2012a). The paper by Lozano-Gracia et al. (2010) set up a gravity model that included the spatial lag of the dependent variable. Their model highlights the importance of spatial contiguous neighbors in the moving decisions. Sayago-Gómez (2012a) also set up a spatial model 
Juan Tomás Sayago-Gómez Chapter 4. Poverty Changes and Forced Migration 58

to account for the conflict effect on expulsion or departure of forced migrants. This model also identified the existence of an area of influence of armed groups. It is measured using spatially lagged variables.

The migration literature has explained migration as the result of an economic or social imbalance between conditions in different places, such as rural and urban areas. The theoretical arguments that explain motives to migrate are based on differences between places, expectations of higher incomes, and expected utility. The basic models have been explained by Sjaastad (1962) and Harris and Todaro (1970). These models have been extended to consider other relevant elements (Brueckner and Zenou, 1999; Atuesta, 2012). They have been tested empirically as summarized by Greenwood (1993) and Lucas (1993). Migration research has considered the differences in income and other relevant amenities to pull people to migrate, but also models such as the gravity model that explain the migration process as part of an equilibrium between regions (Lowry, 1966; Greenwood, 1993; Greenwood and Hunt, 2003).

The motives to migrate in the theoretical models proposed by Sjaastad (1962) and Harris and Todaro (1970) are the expected economic gains from moving from one region to another or from rural to urban areas. These approaches aim to explain the factors that push and pull migrants (Dorigo and Tobler, 1983). They also move towards the development of the gravity model that considers variables that push population and attract population as the distance and population size are the main determinants of migration (Lowry, 1966; Greenwood, 1975, 1985, 1993; Greenwood and Hunt, 2003). As Greenwood and Hunt (2003) argued, the gravity model considers spatial interactions between population and distance. Cushing (1986) emphasizes the specification of distance and space affects the model and results. Greenwood et al. (1991) consider regional amenities, regional wages, and price variables. Additionally new methods and interpretations of migration coefficients are being considered for research, along with new methodologies that consider spatial structure (Cushing and Poot, 2003; Cushing, 
2005a,b; LeSage and Pace, 2008; LeSage and Thomas-Agnan, 2015).

The migration research that has focused mainly on the consequences of migration, is the research that considers the remittances and their effects on developing economies. Previous research found a positive effect of remittance to reduce poverty in different countries of Africa and South America (Adams and Page, 2005; Gupta et al., 2009; Acosta et al., 2008; Adams et al., 2008). Moreover there is mixed evidence that suggests a positive effect from remittances on inequality (Stark et al., 1988) and there are different explanations to the theoretical considerations (Stark et al., 1986; Stark and Lucas, 1988). Additionally the research has found a positive effect of remittances on economic growth (Pradhan et al., 2008; Adams et al., 2008).

Our emphasis is on the effects of forced migration on how migration creates an imbalance in economic conditions, and how forced migrants affect the social and economic structure. Recent studies have considered the effects of migration on economic variables, but this research relates mostly to remittances, and how they affect the conditions in developing countries.

\subsection{Data description}

The data for this chapter come from four different sources: Departamento Administrativo Nacional de Estadisticas (National Department of Statistics - DANE), Departamento Nacional de Planeación (National Department of Planning - DNP), Departamento Administrativo para la Prosperidad Social ( Administrative Department of Social Prosperity - DPS), and Ramirez, Bedoya and Díaz (Ramírez et al., 2016). The poverty measurements (dependent variables) and controls come from DANE, DNP and Ramírez et al. (2016), and the variables related to displacement come from the DPS. Tables 4.1 and 4.2 show the description of the variables used in this chapter and their summary statistics. 
Table 4.1: Brief descriptions of dependent variables and main independent variables.

\begin{tabular}{|c|c|c|c|}
\hline Variable & Description & Source & Year \\
\hline \multicolumn{4}{|c|}{ Dependent Variables } \\
\hline UBNpovpct05 & Percentage of Population in Poverty by Unmet Basic Needs & DANE & 2005 \\
\hline UBNpovpct93 & Percentage of Population in Poverty by Unmet Basic Needs & DANE & 1993 \\
\hline UBNvivpct05 & Percentage of Population in Poverty by Housing Characteristics & DANE & 2005 \\
\hline UBNvivpct93 & Percentage of Population in Poverty by Housing Characteristics & DANE & 1993 \\
\hline UBNserpct05 & Percentage of Population in Poverty by Access to Public Services & DANE & 2005 \\
\hline UBNserpct93 & Percentage of Population in Poverty by Access to Public Services & DANE & 1993 \\
\hline UBNhacpct05 & Percentage of Population in Poverty by Housing Overcrowding & DANE & 2005 \\
\hline UBNhacpct93 & Percentage of Population in Poverty by Housing Overcrowding & DANE & 1993 \\
\hline UBNinapct05 & Percentage of Population in Poverty by Access to Education & DANE & 2005 \\
\hline UBNinapct93 & Percentage of Population in Poverty by Access to Education & DANE & 1993 \\
\hline UBNdeppct05 & Percentage of Population in Poverty by Economic Dependence & DANE & 2005 \\
\hline UBNdeppct93 & Percentage of Population in Poverty by Economic Dependence & DANE & 1993 \\
\hline IPM2005 & Percentage of Population in Poverty by Multidimentional Poverty Index & Ramírez et al. (2016) & 2005 \\
\hline IPM1993 & Percentage of Population in Poverty by Multidimentional Poverty Index & Ramírez et al. (2016) & 1993 \\
\hline \multicolumn{4}{|c|}{ Independent Variables } \\
\hline Displaced $_{1997-2004}$ & Displaced Out Population & DANE & 2005 \\
\hline Arrival $_{1997-2004}$ & Arrival of Displaced Population & DANE & 1993 \\
\hline Total sgp & Government Investment Values in Millions of Pesos & DNP & 1993-2004 \\
\hline Density05 & Density of population & DANE & 2005 \\
\hline Density93 & Density of population & DANE & 1993 \\
\hline
\end{tabular}


Table 4.2: Descriptive Statistics

\begin{tabular}{|c|c|c|c|c|}
\hline Variable & Mean & St. Dev. & Min & Max \\
\hline pop2005 & $41,124.780$ & $245,165.000$ & 885 & $6,840,116$ \\
\hline pop93 & $31,561.940$ & $178,751.300$ & 114 & $4,922,825$ \\
\hline UBNpovpct93 & 0.493 & 0.179 & 0.001 & 0.908 \\
\hline UBNvivpct93 & 0.835 & 0.172 & 0.097 & 0.996 \\
\hline UBNserpct93 & 0.822 & 0.166 & 0.003 & 1.000 \\
\hline UBNhacpct93 & 0.799 & 0.107 & 0.222 & 0.972 \\
\hline UBNinapct93 & 0.876 & 0.068 & 0.549 & 1.000 \\
\hline UBNdeppct93 & 0.798 & 0.073 & 0.517 & 0.968 \\
\hline UBNpovpct05 & 0.578 & 0.183 & 0.028 & 0.946 \\
\hline UBNvivpct05 & 0.823 & 0.166 & 0.134 & 1.000 \\
\hline UBNserpct05 & 0.884 & 0.143 & 0.051 & 1.000 \\
\hline UBNhacpct05 & 0.855 & 0.083 & 0.188 & 0.987 \\
\hline UBNinapct05 & 0.956 & 0.036 & 0.614 & 1.000 \\
\hline UBNdeppct05 & 0.815 & 0.081 & 0.315 & 0.984 \\
\hline Displaced $_{1997-2004}$ & $1,504.703$ & $3,790.443$ & 0 & 52,006 \\
\hline Arrival $_{1997-2004}$ & $1,601.346$ & $6,391.538$ & 0 & 102,818 \\
\hline IPM2005 & 0.758 & 0.146 & 0.245 & 0.999 \\
\hline IPM1993 & 0.987 & 0.010 & 0.889 & 1.000 \\
\hline TOTAL.SGP & $42,862,777$ & $245,399,025$ & $5,001,287$ & $7,248,232,836$ \\
\hline IntExpulsion & 0.111 & 0.447 & 0.000 & 10.912 \\
\hline IntArrival & 0.001 & 0.004 & 0.000 & 0.063 \\
\hline Total sgp pc & 7.345 & 0.502 & 5.943 & 9.306 \\
\hline Density93 & 115.022 & 475.933 & 0.055 & 10561.000 \\
\hline Density05 & 149.160 & 652.280 & 0.690 & 13821.940 \\
\hline
\end{tabular}

\subsubsection{Dependent variables}

The dependent variables are the estimates of the changes in poverty in Colombian municipalities for the period from 1993 to 2005. These changes in poverty are the differences in percentage between time periods. However, there are different ways to measure poverty in Colombia. The different methods try to consider whether or not the living conditions are appropriate. The different methodologies to measure poverty use different variables to account for the relevant characteristics of the condition. Some of these variables overlap between methodologies. 
There are two main classes of methods to measure poverty: the methods that measure poverty in monetary terms and the methods that measure poverty based on non-monetary terms. Monetary estimates of poverty depend on income levels for households: Thus a family is poor when their income is below a certain value. The poverty estimates based on non-monetary terms usually try to answer the question: Do people live in acceptable living conditions? (Feres and Mancero, 2001). The non-monetary approach seeks to evaluate whether households have met their basic needs. The households are surveyed to evaluate if they have access to goods and public services to satisfy these needs (Feres and Mancero, 2001). The poverty measurements used in this paper come from two methodologies: The Unmet Basic Needs (UBN) and the Multidimensional Poverty Index (MPI). These variables are chosen because they estimate the percentage of the population that is considered to be poor (Feres and Mancero, 2001; Angulo et al., 2016; Ramírez et al., 2016). I use the estimates from these two methodologies to estimate the changes in poverty between census periods.

The UBN index classifies as poor the percentage of the total population that does not meet at least one or more of five basic needs. The UBN includes housing characteristics, access to sanitary services, housing conditions, access to education, and economic capacity. Poverty is evaluated for each component and when a household shows a lack in one of the components, it is considered to be poor. If it shows an absence of two or more components, the household is considered to be extremely poor (Feres and Mancero, 2001).

The components of the UBN include information on

- House characteristics that measure the quality of shelter, for example, the material used in walls, roof, and floor.

- Access to sanitary services measured by the availability of the household of a 
water source and the system for elimination of human wastes.

- Housing conditions crowding, such as, the ratio of the size of the house to the number of people living there; three or more people per room is considered overcrowding.

- Access to education measured by school attendance of children aged 7 to 11 .

- Economic capacity measured by the number of dependent persons per working person in the household.

The percentage of the population who are poor decreased according to UBN methodology in Colombian municipalities between 1993 to 2005. The poverty reductions are not the same for all components nor all areas. Table 4.3 shows the reductions in the different components and poverty measurements and Figure 4.1 shows which municipalities decreased their poverty rates.

Table 4.3: Percentage of population with Unmet Basic Needs Total and by Component. Author's Calculation

\begin{tabular}{c|c|c}
\hline Component & 1993 & 2005 \\
\hline House Characteristics & $11.6 \%$ & $10.4 \%$ \\
Access to sanitary & $10.5 \%$ & $7.4 \%$ \\
Services & & \\
Housing conditions & $15.4 \%$ & $11.1 \%$ \\
Access to education & $8.0 \%$ & $3.6 \%$ \\
Economic capacity & $12.8 \%$ & $11.2 \%$ \\
Poverty & $35.8 \%$ & $27.7 \%$ \\
Extreme poverty & $14.9 \%$ & $10.6 \%$ \\
\hline
\end{tabular}


Figure 4.1: Poverty measured by Unsatistied Basic Needs (UBN)

(a) Map of Poverty measured by Unsatisfied Basic Needs on 1993

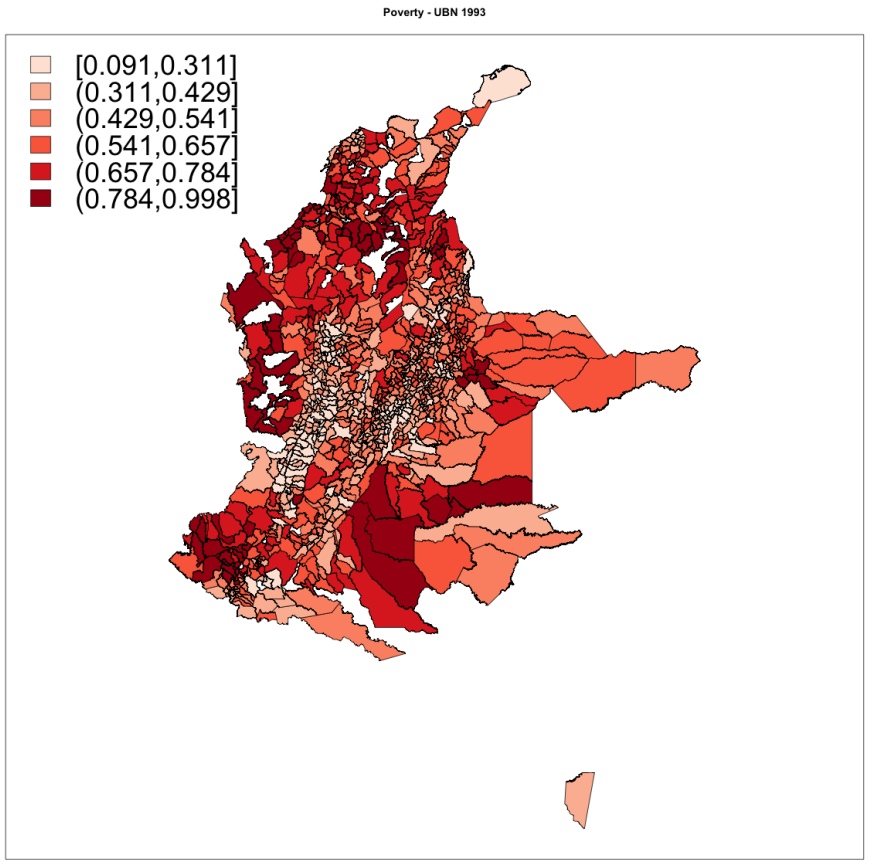

(b) Map of Poverty measured by Unsatisfied Basic Needs on 2005

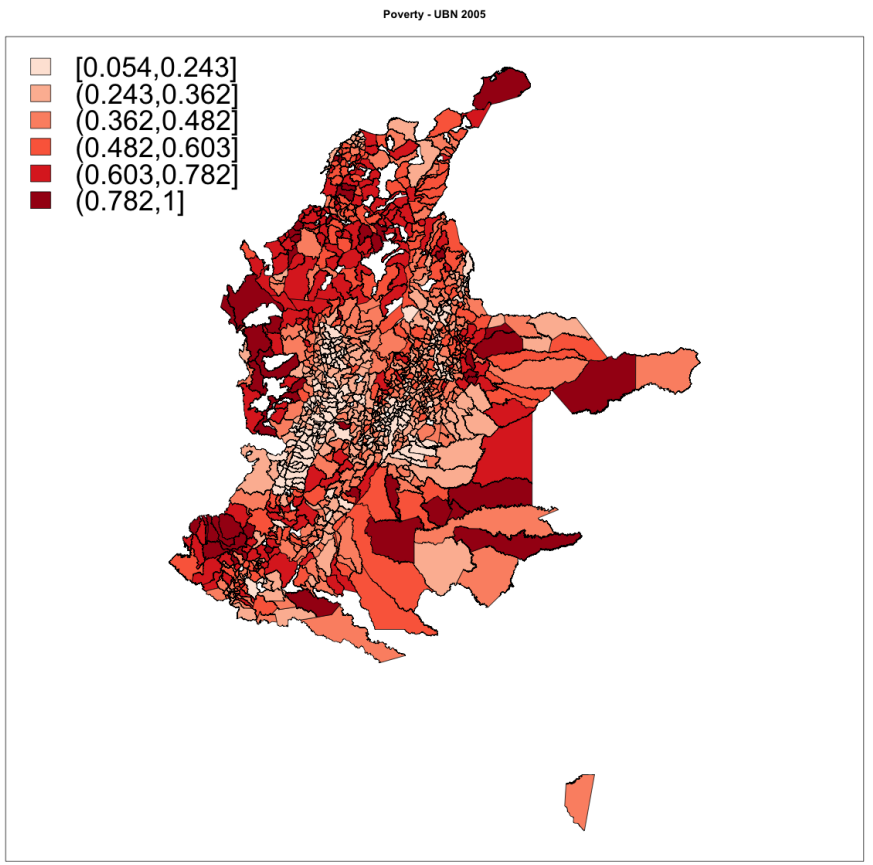


The Multidimensional Poverty Index (MPI) was developed for Colombia by the National Department of Planning based on the index by the Oxford Poverty and Human Development Initiative (OPHI) (Alkire and Foster, 2011a,b). This index composed of five dimensions, all of which have the same relevance and are valued equally, each dimension formed by different variables, each variable has equal weight inside each dimension (Angulo et al., 2011, 2013, 2016; Ramírez et al., 2016).

The components in the MPI includes information on

- Household education condition.

- Childhood and youth conditions.

- Employment.

- Health.

- Access to public utilities and housing conditions.

The dimensions, variables, and weights associated with each variable are in Table 4.4. The MPI is a more complex and more thorough evaluation of poverty, and it was created to measure poverty and to overcome the problems and limitations that existing methodologies had. It produces an estimate of poverty, it does not separate results by components. Figure 4.2 shows the percentage of poor population by municipality in Colombia measured using the MPI.

The change is calculated as the difference between the percentage of non-poor population in municipalities in 1993 and 2005 (See equation (4.1)). One drawback from this estimate is that this measure will not change much when the municipality has already reached high levels. However, it is very sensitive to changes in municipalities with small percentages of non-poor population, which is a key indicator of the bigger 
Table 4.4: Multidimensional Poverty Index by dimensions and variables. Source: Angulo et al. (2013)

\begin{tabular}{|c|c|}
\hline Dimension & Variables \\
\hline Household & Educational achievement (0.1) \\
\hline education & Literacy $(0.1)$ \\
\hline \multirow{4}{*}{$\begin{array}{l}\text { Enditions }(0.2) \\
\text { youth conditions } \\
(0.2)\end{array}$} & School attendance $(0.05)$ \\
\hline & No school lag $(0.05)$ \\
\hline & Access to childcare services $(0.05)$ \\
\hline & Children not working (0.05) \\
\hline \multirow{2}{*}{$\begin{array}{l}\text { Employment } \\
(0.2)\end{array}$} & No one in long-term unemployment $(0.1)$ \\
\hline & Formal employment (0.1) \\
\hline \multirow{2}{*}{ Health $(0.2)$} & Health insurance $(0.1)$ \\
\hline & Access to health services $(0.1)$ \\
\hline \multirow{5}{*}{$\begin{array}{l}\text { Access to public } \\
\text { utilities and } \\
\text { housing } \\
\text { conditions }(0.2)\end{array}$} & Access to water source $(0.04)$ \\
\hline & Adequate elimination of sewer waste $(0.04)$ \\
\hline & Adequate floors (0.04) \\
\hline & Adequate external walls (0.04) \\
\hline & No critical overcrowding (0.04) \\
\hline
\end{tabular}

problem of measurements such as the UBN. My interest is the change in poverty, coefficients with positive values decreasing poverty and coefficients with negative values increasing poverty. Figure 4.3 shows the change in UBN by component in the Colombian municipalities.

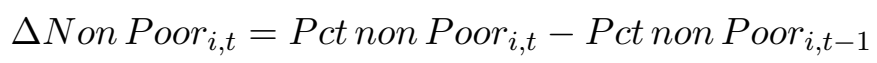

\subsubsection{Independent variables}

The independent variables used in this paper include variables related to government investment, the concentration of population and the proportion of urban population. Government investment data come from the National Department of Planning (DNP). The variables related to population come from the DANE.

These variables will account for government investment to decrease poverty. The 
central government issued regulations related to required percentages of total investment that should help reduce poverty in the municipalities, some by construction of new infrastructure and others by improving the current infrastructure to provide sustainability. This distribution is part of the General System of Contributions (SGP). This system gives importance to the policy of social reactivation. Social Reactivation aims to achieve poverty reduction and it uses "seven tools of equity": "(i) an education revolution; (ii) social protection and social security; (iii) economic development for the benefit of all; (iv) social management of the countryside; (v) social management of public services; (vi) a country of owners; and (vii) quality of urban life. These matters are discussed later in this report" (UN Committee on Economic and , CESCR, p. 23). According to SGP the investments aiming at social reactivation should be around 60 percent of investment resources in afiscal year.

The variables that relate to urban population and population density aim to account for the costs of construction of infrastructure, since Colombia has a large rural area (Machado, 2011; Sayago-Gómez, 2012b). The costs of building an infrastructure to reduce poverty in rural municipalities is higher than in urban municipalities. Additionally, another variable that could account for costs of construction of infrastructure is the density of population. Municipalities that are densely populated will face lower cost of investment because the population is concentrated in smaller spaces.

The DPS publishes data related to displacement: the expulsions and arrival of forced migrants in Colombia. This information is reported from 1997 to 2016 for every municipality. Migrant information is recorded by migrant ID, which allows DPS to follow migrants for additional moves. Forced migrants from an earlier time are also allowed to register and can possibly receive benefits if they meet the requirements. I standardize the number of migrants using the intensity of expulsion and intensity of arrival. These measures are similar to the ones used by Sayago-Gómez (2012a). 
The intensity of expulsion is the estimate of the share of migrants pushed out divided by the total population in the municipality. Therefore it is the population forced to migrate out $\left(\right.$ Forcedout $\left._{i}\right)$ divided by the population $\left(\right.$ Pop $\left._{i}\right)$ in the municipality that they leave. This estimate is the share of population that migrated out (equation (4.2)).

The intensity of arrival is a measure of share of population displaced to a municipality $\left(\right.$ Migrain $\left._{i}\right)$ divided by the population in the receiving municipality (PopRec), it measures the share of migrants that arrived to a specific city over all population in the city where they arrived. Therefore equation (4.3) uses the population that migrated to a specific municipality divided by the population $\left(P o p_{i}\right)$ in the receiving municipality ${ }^{1}$. Figure 4.4 shows the map of the estimates of Intensity of Expulsion and Arrival by municipality in Colombia.

$$
\begin{gathered}
\text { Int } \operatorname{Exp}_{i}=\frac{\text { Forcedout }_{i}}{\text { Pop }_{i}} \\
\text { Int } \operatorname{Arr}_{i}=\frac{\text { Migrain }_{i}}{\text { PopRec }_{\text {Rerain }}}=\frac{\text { Migrap }_{i}}{\text { Pop }_{i}}
\end{gathered}
$$

\footnotetext{
${ }^{1}$ I estimated another intensity of arrival. It uses the population that migrated to a specific municipality divided by the population that migrated.

$$
\text { Int } \text { Arr }_{i}=\frac{\text { Migrain }_{i}}{\sum_{i=1}^{I} \operatorname{Migrain}_{i}}
$$

The results for the analysis highlight the effect of expulsion but hides the effect of arrival in municipalities where the population that arrives is a significant share of the total population of the municipality.
} 
Figure 4.2: Poverty measured by Multidimensional Poverty Index (MPI)

(a) Map of Poverty measured by Multidimensional Poverty Index on 1993

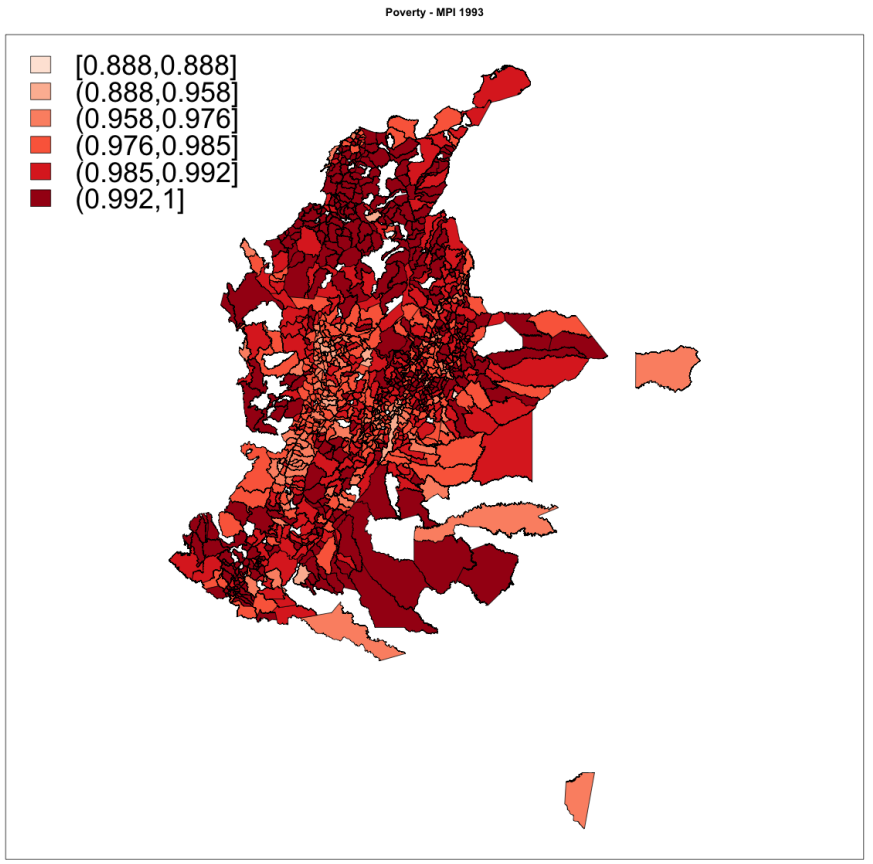

(b) Map of Poverty measured by Multidimensional Poverty Index on 2005

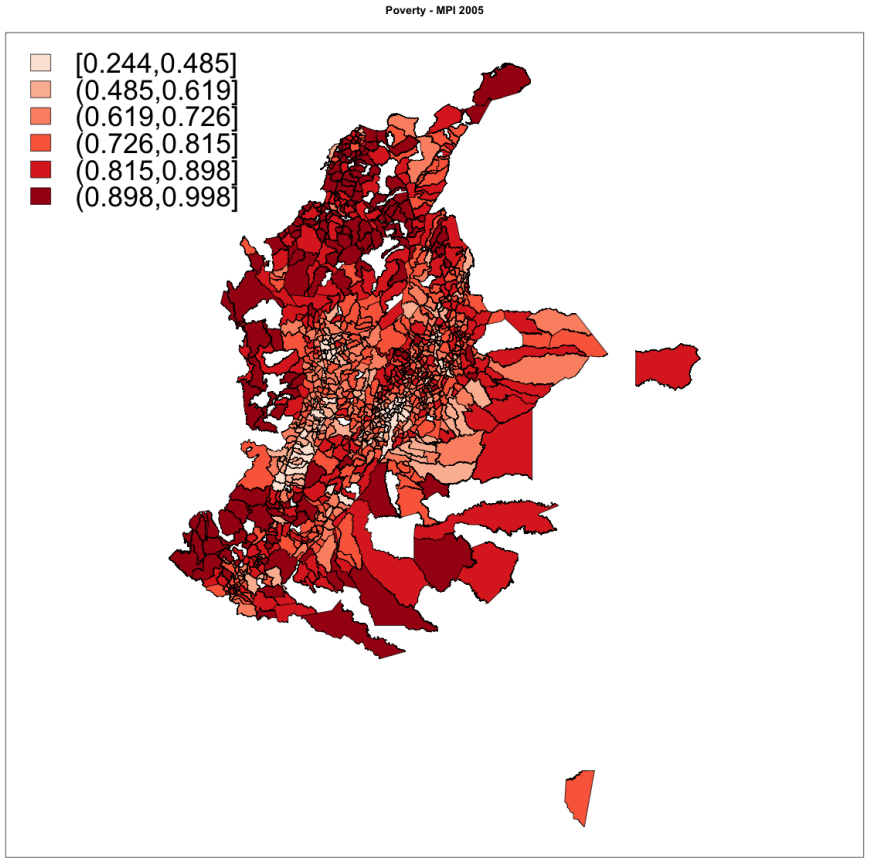


Figure 4.3: Change in the UBN in the municipalities

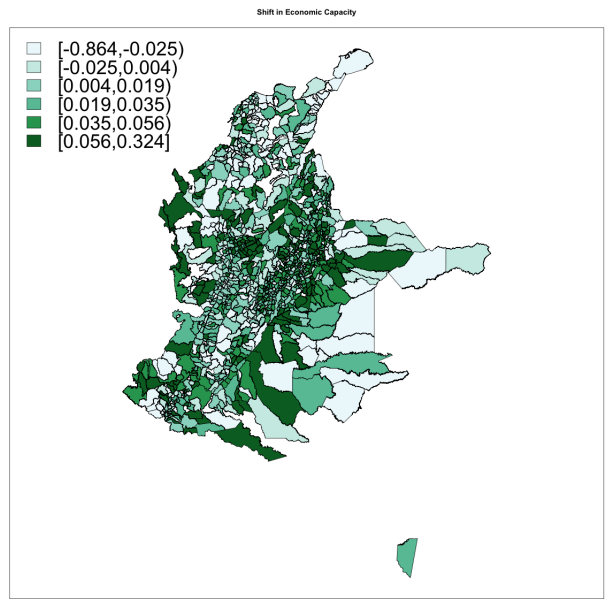

(a) Economic dependence

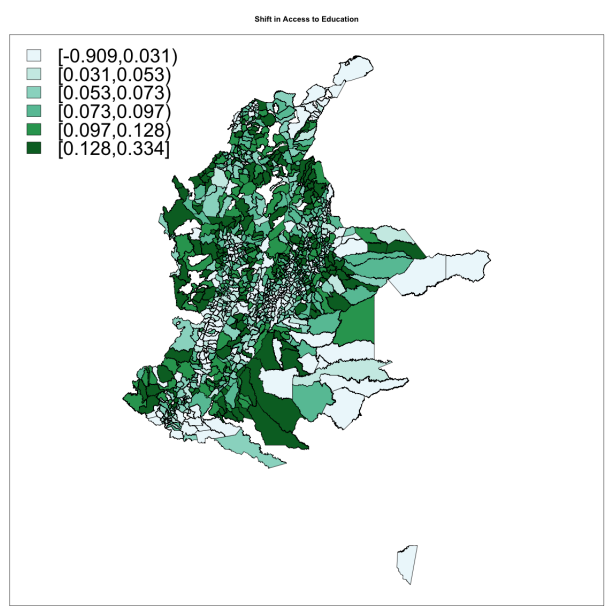

(c) School attendance

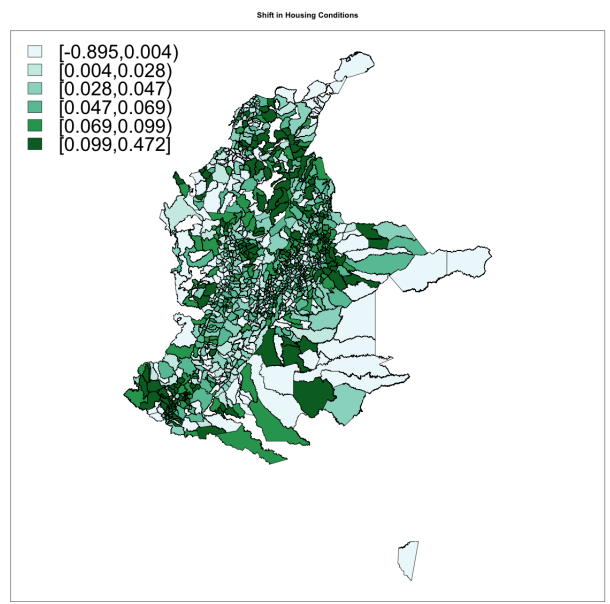

(b) Housing Conditions

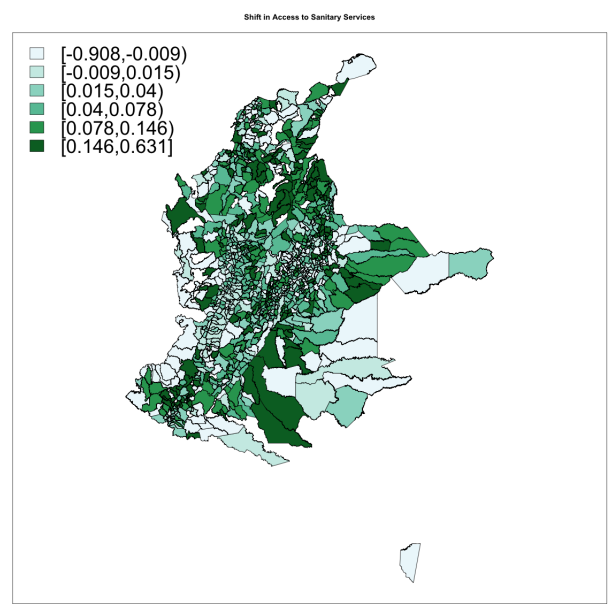

(d) Public services

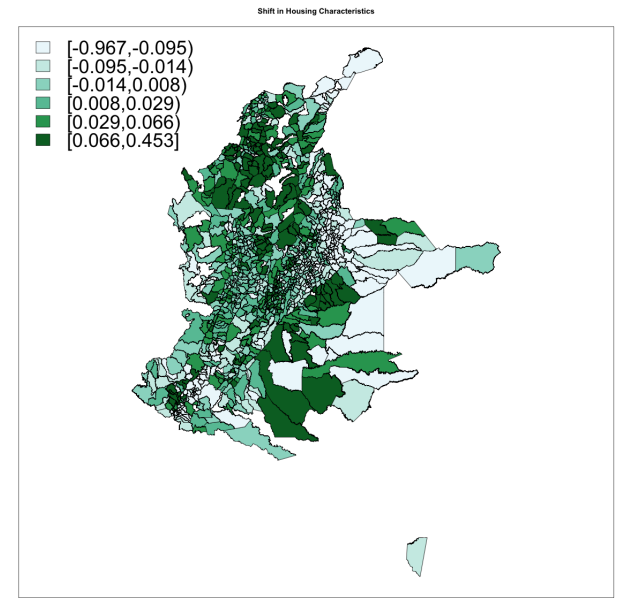

(e) House characteristics 
Figure 4.4: Forced Displacement

(a) Intensity of Expulsion

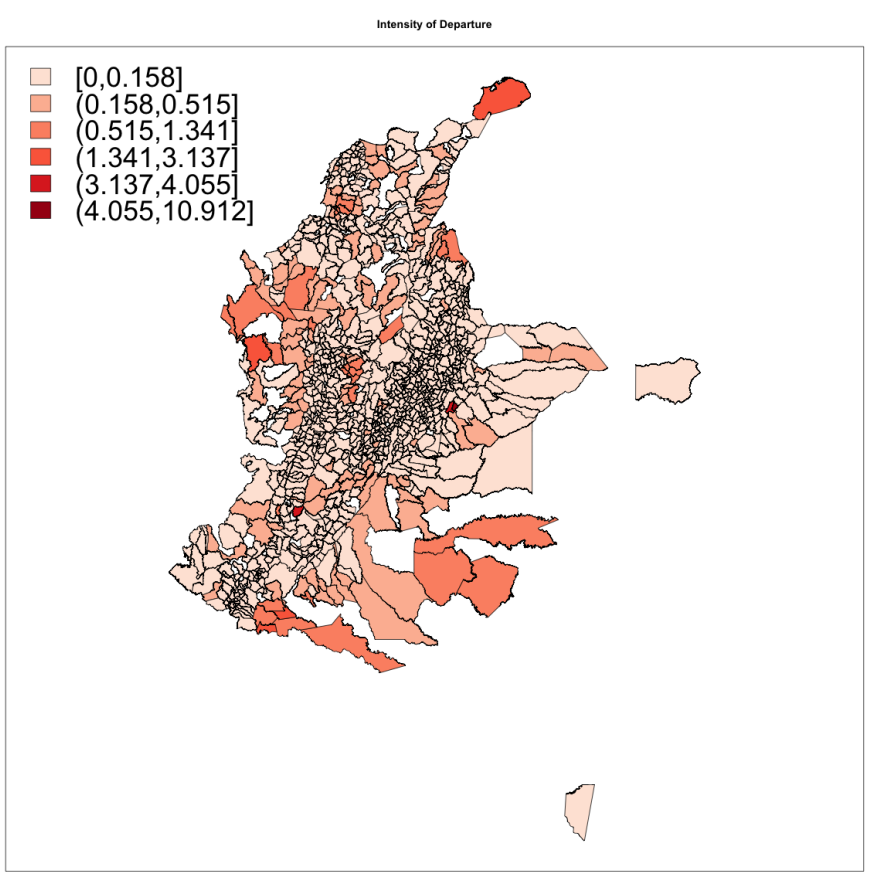

(b) Intensity of Arrival

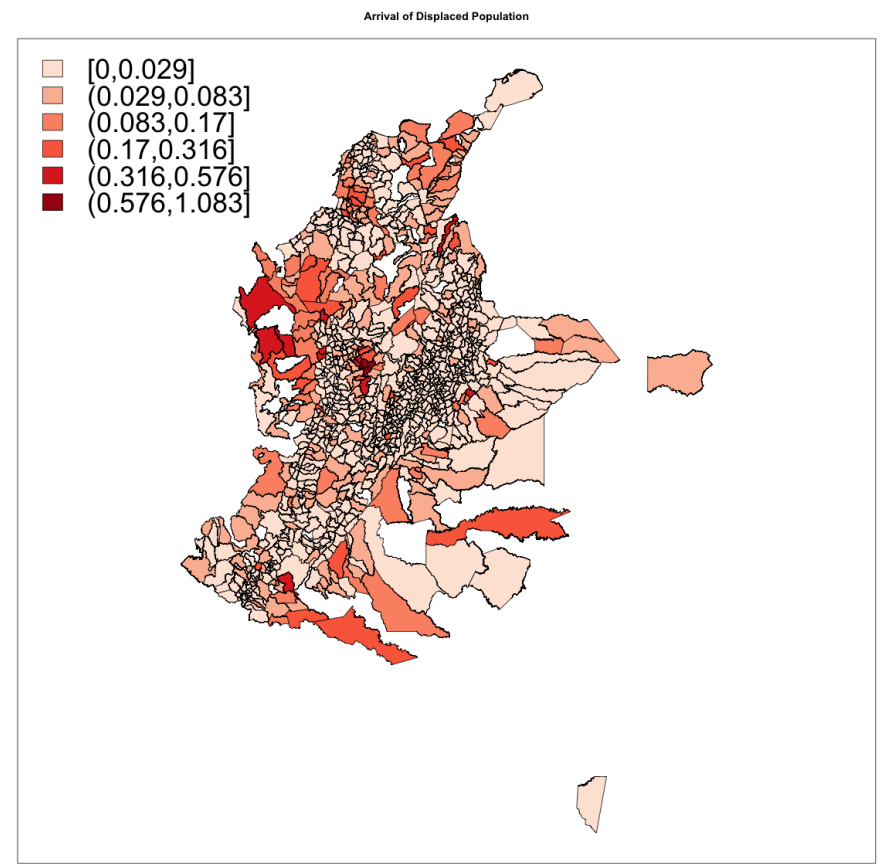


Juan Tomás Sayago-Gómez Chapter 4. Poverty Changes and Forced Migration

\subsection{An application of Shift-Share analysis to poverty}

In order to evaluate the difference in the poverty reductions and the population movements, I estimate a Shift-Share decomposition to highlight the effect of changes in the number of non-poor population instead of using and focusing on the proportion of population that is poor. This analysis relies on the estimates of poor and non-poor population, and it estimates the change in non-poor population for the two periods of analysis.

Shift-Share Analysis is used mostly to analyze changes in employment and value added. It is a tool used to design regional policy and identify the sectors that lead growth and those that are lagging. Recent applications have focused on population changes to identify what regions and population groups experienced higher growth rates compared with other groups and the nation. Additionally the method allows the identification of regions that undergo declines in population. This analysis helps distinguish changes in composition of population because it considers racial and ethnic growth rates (Franklin, 2012). The following application follows a strategy similar to the application developed by Franklin and Plane (2004) and Franklin (2012).

\subsubsection{Shift-Share decompositions}

Shift-Share is a method used in Regional Science since the 1960s to decompose regional employment and value added growth (Loveridge and Selting, 1998; Capello, 2007; Jackson and Haynes, 2009). Traditionally Shift-Share decomposes regional change into: (1) the national growth effect, (2) the industry mix effect, and (3) the competitive effect. The classic Shift-Share model is presented in equation (4.4); it shows how rearranging the growth rates will provide a decomposition from the additive cases.

$$
\Delta e_{i, t}=\left(G+\left(G_{i}-G\right)+\left(g_{i}-G_{i}\right)\right) e_{i, t-1}
$$


where

- $e_{i, t}$ is the employment at time $t$ in the $i$ th sector

- $\Delta e_{i, t}$ is the growth rate of employment from time $t-1$ to $t$ in the $i$ th sector

- $G$ is the National Growth rate. Also called the National Effect.

- $\left(G_{i}-G\right)$ is the difference between national growth rates for sector $i$ and all the sectors. It is also called the Industry Mix Effect.

- $\left(g_{i}-G_{i}\right) e_{i}$ is the difference between the growth rates for sector $i$ for the region and the country. It is also called the Competitive Effect.

The previous Shift-Share equation can be rearranged for simplicity to only include growth rates:

$$
g_{i}=\left(G+\left(G_{i}-G\right)+\left(g_{i}-G_{i}\right)\right)
$$

The National effect $(G)$ is the amount the region would have changed had it changed at the same rate as the national economy ${ }^{2}$. The industry mix shows how the region would have changed had its industry mix matched that of the nation, assuming each sector has uniform growth within nation. In equation (4.4), it involves the difference between the country's growth rate of the sector $i$ with respect to the country $\left(G_{i}-G\right)$. The Competitive Effect captures how growth in the region's sectors differ from the national average $\left(g_{i}-G_{i}\right)$.

Shift-Share is widely used in regional analysis because it is a simple procedure that uncovers dynamic transformations in sectors and only requires modest amounts

\footnotetext{
${ }^{2}$ Loveridge and Selting (1998), and Jackson and Haynes (2009) explained that this identity says that the growth rate for the industries in the region should be similar to the growth rate for the national industry
} 
of data (Stevens and Moore, 1980; Nazara and Hewings, 2004). Many improvements to Shift-Share were developed to correct potential issues. These transformations can help capture other effects in regional changes (Esteban-Marquillas, 1972; Nazara and Hewings, 2004). Additionally Nazara and Hewings (2004) have proposed to include the spatial structure or neighboring relations in the Shift-Share analysis to account for spatial interactions and compositions of neighbors ${ }^{3}$. Applications of Shift-Share analysis have also focused on changes in other variables. Franklin and Plane (2004) apply Shift-Share to fertility rates in Italy to explain population change trends, Plane (1987) and Plane (1992) used it to explain migration trends. Franklin (2012) applied it to population changes. Shift-Share analysis shows the linkages between local, regional and national trends.

These decompositions allow us to highlight which regions have improved more than others and reveals the sectors responsible for the improvements. It will also show which regions are lagging and in which components. I use Shift-Share to evaluate changes in poverty between different municipalities. It will allow me to distinguish between those municipalities that really improved and those that improved their UBN but did not reduce the number of poor.

\subsubsection{Data requirement for the Shift-Share analysis to poverty}

Data for the Shift-Share come from the Census in years 1993 and 2005 and show the percentage of population classified as poor according to the UBN methodology and by each component for each municipality ${ }^{4}$. The percentage UBN is presented in Figures 4.1a and 4.1b. We calculate the population that is not classified in UBN to measure the improvement in population that is not poor and use these estimates to decompose

\footnotetext{
${ }^{3}$ Nazara and Hewings (2004) proposed to include the observations of the neighbors to account for the industry mix and competitive effect compared to the neighboring areas.

${ }^{4}$ The municipality is the decentralized subdivision of Colombia. They form departments which are equivalent to the states in the United States. Each municipality has its own mayor elected by popular vote, and one municipality in each department is the capital.
} 
The Shift-Share analysis of poverty will analyze the changes in population classified as not poor. The different sectors will be the different components in the different departments. The classical Shift-Share in equation (4.6) includes the growth of not poor population in the country $(G)$ and the growth of not poor population in the country by the $i$ component $\left(G_{i}\right)$. The growth rate of the not poor population in each department by the $i$ component $\left(g_{i}\right)$. The estimated effects are the national $(G)$, national-regional component change $\left(G_{i}-G\right)$ and the trend differential in the region $\left(g_{i}-G_{i}\right)$ (Franklin, 2012).

$$
g_{i}=G+\left(G_{i}-G\right)+\left(g_{i}-G_{i}\right)
$$

\subsubsection{Results of the Shift-Share analysis}

The results from the Shift-Share analysis show that, for all components, the national regional component change is negative, which means that all the components have lower growth than the total poverty (see Table 4.5). This result can be understood that improvement in all components together is higher than the improvement from a specific component because all sectoral improvements were partially outgrown by the total.

The Competitive Effect in the change of non-poor population by municipality and

Table 4.5: Shift-Share decomposition of poverty - National regional Component change

\begin{tabular}{||c||c|c|c|c|c||}
\hline Component & $\begin{array}{c}\text { House } \\
\text { Characteristics }\end{array}$ & $\begin{array}{c}\text { Housing } \\
\text { Conditions }\end{array}$ & $\begin{array}{c}\text { Access to } \\
\text { Sanitary services }\end{array}$ & $\begin{array}{c}\text { Economic } \\
\text { Capacity }\end{array}$ & $\begin{array}{c}\text { Access to } \\
\text { Education }\end{array}$ \\
\hline Change & $-0.1302 \%$ & $-0.0892 \%$ & $-0.1063 \%$ & $-0.1277 \%$ & $-0.0928 \%$ \\
\hline
\end{tabular}


component is presented in Figure 4.5. It is easier to present the result of the Shift-Share methodology in a map because we have results for 1008 municipalities. The results show concentrations of greater change for all the components in the most populated departments. ${ }^{5}$ Antioquia, Atlantico, Bogotá, Cauca, Cundinamarca, Nariño, and Valle del Cauca. Another group of faster growth is the oil producing departments Arauca and Casanare. These departments receive royalties to invest in poverty reductions. However the increase in non-poor population could be the result of migration to work in areas related to oil production. The municipalities that show a low or negative trend in most of the components are Choco, Norte de Santander, Caldas, Boyaca, Magdalena, Risaralda, and Tolima. In these departments the changes are mainly low or negative.

We can notice in Figure 4.5 that some of the municipalities show similar improvement in all components which could be related to economic immigration for employment. However employment information is not available for Colombian municipalities. I highlight that the change observed in Figure 4.3 and the change observed in Figure 4.5 show certain similarities and differences. These differences can be traced to changes observed in Figure 4.4, because the municipalities that improved in Figure 4.5 receive a large group of displaced population.

\subsection{Empirical strategy}

Reduction of poverty is one of the most important goals of economic policy in developing countries. To evaluate if displacement caused the decline in poverty measured by UBN, I set up a model where I assess the sources of the changes in poverty in Colombian municipalities. This model includes variables that should affect positively and negatively the change in poverty. One of the variables is the investments made by the government because each municipality receives funds for inversions to improve

\footnotetext{
${ }^{5}$ The department is the administrative unit comparable to a State.
} 
living conditions. Another relevant variable is the density of population because it is related to the population that could live in these municipalities. Furthermore, those municipalities with a higher concentration of population face significantly lower costs to provide access to utilities.

Since the main hypothesis of this paper relies on the measurement of the effect of displacement on poverty in Colombia, I set up this model to test the effect of forced migration on changes in poverty in Colombian municipalities. The displacement of the population in Colombia affects the measurements of poverty through its effect on the distribution of the poor population.

The econometric model is defined in equation (4.7),

$$
\begin{aligned}
\Delta \text { Non Poor }_{i, t} & =\beta_{0}+\beta_{1} \text { Arr }_{i}+\beta_{2} \operatorname{Exp}_{i} \\
& +\beta X_{i}+u_{i}
\end{aligned}
$$

where our variable $\left(\Delta\right.$ Pov $\left._{i}\right)$ measures the change in poverty from 1993 to 2005 . The variables Arrival $\left(A r r_{i}\right)$ and Expulsion $\left(\operatorname{Exp}_{i}\right)$ are the variables that quantify the forced displacement in the different municipalities. The variables included in $X$ are other controls related to changes in poverty, such as investments, or population density.

The displacement variables, as previously defined by Sayago-Gómez (2012a), are the intensity of expulsion and intensity of arrival. These variables are standardized to consider the effect of the population at a point of origin as a standardizing variable for expulsion. The total number of the displaced population arriving is the denominator for the intensity of arrival. The intensity of arrival is standardized differently to avoid bias in the result when large cities receive displaced population.

We follow the methodology set up by Arbia (2014), Elhorst (2010), and Elhorst 
(2014) to estimate the appropriate model that measures the changes in poverty in the Colombian municipalities. According to this strategy, there are seven models that could potentially fit the data: (1) Ordinary Least Squares (OLS), (2) Spatial Autoregressive Model (SAR), (3) Spatial Error Model (SEM), (4) Spatial Lag of X (independent variables) Model (SLX), (5) Spatial Durbin Model (SDM), (6) Spatial Durbin Error Model (SDEM), or (7) Spatial Autoregressive with additional Autoregressive error structure (SARAR also denominated SAC by LeSage and Pace (2010)). This testing procedure points towards the existence of spatial dependence in the data. Furthermore, the procedure will suggest which model is the most appropriate to fit the data.

$$
\begin{gathered}
y=X \beta_{1}+\lambda W y+W X \beta_{2}+u \\
u=\rho W u+\varepsilon
\end{gathered}
$$

where the $y$ is an $n \times 1$ vector of cross-sectional observations, also known as the dependent variable. $X$ is an $n \times m$ matrix of independent variables that affect the dependent variable. $\beta_{1}$ and $\beta_{2}$ are two $m \times 1$ vectors of coefficients associated with the independent variables and neighbors average of the independent variables. All these models assume the existence of a $W$ matrix or weight matrix. This $W$ matrix is an $n \times n$ matrix that defines neighbor relations. The parameters $\rho$ and $\lambda$ are scalar parameters that represent the spatial relationship associated with the error term and dependent variable $y$.

The equations that define the seven models are considered by setting parameters equal to zero in equations (4.8) and (4.9) (Elhorst, 2010, 2014; Arbia, 2014). The models are:

1. The OLS model is the aspatial model, and it assumes that $\beta_{2}=0, \lambda=0$, and 
$\rho=0$.

2. The SAR model includes a spatial dependence on the $y$ variable. The dependent variable of a unit interacts with its neighbor: $\beta_{2}=0, \rho=0$, and $\lambda \neq 0$.

3. The SEM includes a spatial interaction between the error terms, and it is consistent with a model where the omitted determinants, are spatially autocorrelated: $\beta_{2}=0, \lambda=0$, and $\rho \neq 0$.

4. The SLX model includes exogenous interaction effects, where the neighbor's independent variables affect the dependent variable: $\lambda=0, \rho=0$, and $\beta_{2} \neq 0$.

5. SDM includes spatial dependence on the dependent variables and the neighbors' independent variables: $\rho=0, \beta_{2} \neq 0$, and $\lambda \neq 0$.

6. SDEM includes spatial interaction between error terms and the neighbor's independent variables: $\lambda=0, \beta_{2} \neq 0$, and $\rho \neq 0$.

7. The SARAR model includes the spatial dependence on the dependent variables and the spatial interaction between the error terms: $\beta_{2}=0$ and $\lambda \neq 0$, and $\rho \neq 0$.

To select which model will fit the data generating process most accurately, we follow the methodology set up by Arbia (2014), Elhorst (2010), and Elhorst (2014). First, we run the OLS model with all the variables, also considering the model with fixed effects. Afterward, we estimate the Lagrange multiplier tests (LM) to evaluate the existence of spatial dependence in the error term of the dependent variable (Anselin et al., 1996). The robust versions of the tests consider the presence of the other forms of spatial dependence (Anselin et al., 1996).

The results from the specification tests and our theoretical considerations of what observed relations contribute to the studied phenomena will point us towards the most 
appropriate model. However, we should consider the arguments in previous literature to portray which spatial model was relevant to the problem at hand. Sayago-Gómez (2012a) suggested the SEM and SDEM as appropriate models to represent the spatial dependence existing in forced displacement and the presence of armed groups in the municipalities of Colombia. Ramírez et al. (2016) estimate a SAR model for the percentage of the poor population in Colombian municipalities. Their approach is different from ours because they estimate a model that has the level or share of the poor population as their dependent variable while this analysis focuses on the change.

As stated previously, both forced displacement and poverty have a spatial component (Lozano-Gracia et al., 2010; Sayago-Gómez, 2012a; Ramírez et al., 2016). The spatial component of forced displacement has been explained by Sayago-Gómez (2012a) as armed groups have larger areas of impact. They do not stay in one place, but move around regions since they move mostly by walking, and they can go around in any direction in the regions. These areas of impact provide a local effect on the neighboring municipalities. The spatial local effect is similar to the spatial effect associated with the Spatial Durbin Error Model according to the theoretical approach by LeSage (2014).

\subsection{Results from immigration and poverty}

The regression results shows the effect of displacement on poverty in Colombian municipalities. It will be presented according to the measurement and poverty dimension or characteristic. We first analyze the change in total poverty from the UBN methodology. Then we explore the changes in the different components or dimensions. The final analysis examines the change using the MPI methodology and the estimates from Ramírez et al. (2016). The comparison will show which measures of poverty change are affected by the population movements. 
The testing procedure results for the model that analyzes the change in total poverty are in Table 4.6. The results of the LM test reject the null hypothesis, supporting both of the Spatial lag model and Spatial Error Model. The Robust LM test reject only for the spatial lag model. This result points toward the spatial lag model. However, as already pointed by Sayago-Gómez (2012a) the spatial component related to expulsion in Colombia tends to follow a model that has missing spatially independent variables. Thus the robust test results contradict the theoretically preferred hypothesis, I will follow the theoretical assumptions for the model and use the Spatial Error Model.

Table 4.6: Lagrange Multiplier Test for Total Poverty Regressions

\begin{tabular}{cccc}
\hline \hline Test & Statistics & df & p-value \\
\hline LMerr & 86.050 & 1 & 0.000 \\
LMlag & 90.836 & 1 & 0.000 \\
RLMerr & 1.547 & 1 & 0.214 \\
RLMlag & 6.334 & 1 & 0.012 \\
SARMA & 92.384 & 2 & 0.000 \\
\hline
\end{tabular}

The testing procedure applied for the following analysis of poverty focuses on the poverty changes by component: the test for housing characteristics in Table 4.7, the test for access to utilities in Table 4.8, housing conditions in Table 4.9, access to education in Table 4.10, and economic capacity in Table 4.11. The results from these tests are similar to the ones for total poverty measured by UBN. These results reject the null hypothesis that allows consideration of the spatial model. It is noticeable how the robust test procedures highlight the SAR model as the more appropriate, however, as stated in the last paragraph, theory advocates for the use of the SEM and SDEM.

The Lagrange multiplier tests for the model using the MPI are included in Table 4.12. These tests reject the null hypothesis in favor of the spatial model and the robust tests are rejected for both models and the statistic is higher for the spatial error. This result supports the SEM and SDEM as selected to better fit the data. 
Table 4.7: Lagrange Multiplier Test for Housing Characteristics Poverty Regressions

\begin{tabular}{cccc}
\hline \hline Test & Statistics & df & p-value \\
\hline LMerr & 572.715 & 1 & 0.000 \\
LMlag & 601.240 & 1 & 0.000 \\
RLMerr & 1.092 & 1 & 0.296 \\
RLMlag & 29.616 & 1 & 0.000 \\
SARMA & 602.332 & 2 & 0.000 \\
\hline
\end{tabular}

Table 4.8: Lagrange Multiplier Test for Access to Utilities Poverty Regressions

\begin{tabular}{cccc}
\hline \hline Test & Statistics & df & p-value \\
\hline LMerr & 79.975 & 1 & 0.000 \\
LMlag & 80.211 & 1 & 0.000 \\
RLMerr & 0.157 & 1 & 0.692 \\
RLMlag & 0.393 & 1 & 0.531 \\
SARMA & 80.368 & 2 & 0.000 \\
\hline
\end{tabular}

Table 4.9: Lagrange Multiplier Test for Housing Conditions Poverty Regressions

\begin{tabular}{cccc}
\hline \hline Test & Statistics & df & p-value \\
\hline LMerr & 229.121 & 1 & 0.000 \\
LMlag & 246.120 & 1 & 0.000 \\
RLMerr & 3.990 & 1 & 0.046 \\
RLMlag & 20.989 & 1 & 0.000 \\
SARMA & 250.110 & 2 & 0.000 \\
\hline
\end{tabular}

Table 4.10: Lagrange Multiplier Test for the Access to Education Poverty Regressions

\begin{tabular}{cccc}
\hline \hline Test & Statistics & df & p-value \\
\hline LMerr & 321.822 & 1 & 0.000 \\
LMlag & 325.824 & 1 & 0.000 \\
RLMerr & 9.769 & 1 & 0.002 \\
RLMlag & 13.771 & 1 & 0.000 \\
SARMA & 335.593 & 2 & 0.000 \\
\hline
\end{tabular}


Table 4.11: Lagrange Multiplier Test for Economic Capacity Poverty Regressions

\begin{tabular}{cccc}
\hline \hline Test & Statistics & df & p-value \\
\hline LMerr & 123.626 & 1 & 0.000 \\
LMlag & 136.728 & 1 & 0.000 \\
RLMerr & 8.076 & 1 & 0.004 \\
RLMlag & 21.178 & 1 & 0.000 \\
SARMA & 144.804 & 2 & 0.000 \\
\hline
\end{tabular}

Table 4.12: Lagrange Multiplier Test for Total Poverty Regressions from MPI

\begin{tabular}{cccc}
\hline \hline Test & Statistics & df & p-value \\
\hline LMerr & 941.084 & 1 & 0.000 \\
LMlag & 834.191 & 1 & 0.000 \\
RLMerr & 129.781 & 1 & 0.000 \\
RLMlag & 22.889 & 1 & 0.000 \\
SARMA & 963.972 & 2 & 0.000 \\
\hline
\end{tabular}

Table 4.13 includes the regression results for the effect of forced migration on change in total poverty by UBN. The coefficient found for Int.Expulsion is negative and not significant and close to zero and the Int.Arrival is positive and significant. This coefficient means that municipalities that received more forced displaced population will show a bigger decrease in poverty. The coefficient for arrival of displaced population is significant and positive in the a-spatial model, fixed effects model, SEM, and SDEM. The coefficient associated with the $\log$ of investments $(\log (S G P))$ is negative and significant. This result is consistent with larger cities having above $90 \%$ of population non-poor on the UBN and with high investments to maintain access to amenities. The results from the spatial error model show that the spatial coefficient $\lambda$ is positive and significant.

The regression results for housing characteristics show a positive coefficient associated with Int.Expulsion. Table 4.14 shows a positive and significant coefficient 
Juan Tomás Sayago-Gómez Chapter 4. Poverty Changes and Forced Migration 84

Table 4.13: Spatial Regression Results for Total Poverty Measured by UBN.

\begin{tabular}{|c|c|c|c|c|}
\hline & $(\mathrm{OLS})$ & (OLS-FE) & $(\mathrm{SEM})$ & $(\mathrm{SDEM})$ \\
\hline Int. Expulsion & $\begin{array}{l}-0.007 \\
(0.026)\end{array}$ & $\begin{array}{l}-0.034 \\
(0.026)\end{array}$ & $\begin{array}{l}-0.020 \\
(0.026)\end{array}$ & $\begin{array}{l}-0.035 \\
(0.027)\end{array}$ \\
\hline Int. Arrival & $\begin{array}{c}0.150^{* * *} \\
(0.056)\end{array}$ & $\begin{array}{c}0.195^{* * *} \\
(0.055)\end{array}$ & $\begin{array}{l}0.139^{* *} \\
(0.054)\end{array}$ & $\begin{array}{l}0.132^{* *} \\
(0.055)\end{array}$ \\
\hline $\log (\mathrm{SGP})$ & $\begin{array}{c}-0.015^{* * *} \\
(0.005)\end{array}$ & $\begin{array}{c}-0.011^{* *} \\
(0.005)\end{array}$ & $\begin{array}{c}-0.013^{* *} \\
(0.005)\end{array}$ & $\begin{array}{c}-0.014^{* * *} \\
(0.005)\end{array}$ \\
\hline Pct urban & $\begin{array}{c}0.025 \\
(0.015)\end{array}$ & $\begin{array}{c}0.014 \\
(0.017)\end{array}$ & $\begin{array}{c}0.014 \\
(0.016)\end{array}$ & $\begin{array}{c}0.015 \\
(0.016)\end{array}$ \\
\hline Density & $\begin{array}{c}0.00000 \\
(0.00001)\end{array}$ & $\begin{array}{l}-0.00000 \\
(0.00001)\end{array}$ & $\begin{array}{c}0.00000 \\
(0.00001)\end{array}$ & $\begin{array}{c}0.00000 \\
(0.00001)\end{array}$ \\
\hline lag Int. Expulsion & & & & $\begin{array}{c}0.030 \\
(0.060)\end{array}$ \\
\hline lag Int. Arrival & & & & $\begin{array}{l}0.089 \\
(0.130)\end{array}$ \\
\hline lag $\log (\mathrm{SGP})$ & & & & $\begin{array}{l}0.005 \\
(0.004)\end{array}$ \\
\hline lag Pct Urban & & & & $\begin{array}{c}0.005 \\
(0.030)\end{array}$ \\
\hline lag Density & & & & $\begin{array}{c}0.00000 \\
(0.00001)\end{array}$ \\
\hline Constant & $\begin{array}{c}0.332^{* * *} \\
(0.083)\end{array}$ & & $\begin{array}{c}0.298^{* * *} \\
(0.085)\end{array}$ & $\begin{array}{l}0.225^{* *} \\
(0.102)\end{array}$ \\
\hline$\lambda$ & & & $\begin{array}{c}0.375^{* * *} \\
(0.042)\end{array}$ & $\begin{array}{c}0.375^{* * *} \\
(0.042)\end{array}$ \\
\hline Observations & 980 & 980 & 980 & 980 \\
\hline $\mathrm{R}^{2}$ & 0.020 & 0.139 & & \\
\hline Adjusted $\mathrm{R}^{2}$ & 0.015 & 0.108 & & \\
\hline Log Likelihood & & & 966.513 & 969.381 \\
\hline$\sigma^{2}$ & & & 0.008 & 0.008 \\
\hline $\begin{array}{l}\text { Akaike Inf. Crit. } \\
\text { Residual Std. Error }\end{array}$ & $0.094(\mathrm{df}=974)$ & $0.089(\mathrm{df}=945)$ & $-1,917.026$ & $-1,912.762$ \\
\hline Wald Test $(\mathrm{df}=1)$ & & & $79.334^{* * *}$ & $78.862^{* * *}$ \\
\hline LR Test $(\mathrm{df}=1)$ & & & $72.247^{* * *}$ & $71.526^{* * *}$ \\
\hline
\end{tabular}


associated with arrival of displaced population and the percentage of urban population. The coefficient related to investments is negative and significant in the spatial models. This result agrees with the hypothesis that displaced population achieve living conditions that are more achievable in urban areas, where better housing conditions are a basic requirement for constructions. This improves housing characteristics but does not decrease their poverty conditions. The spatial error coefficient is positive and significant. One important detail to highlight is the Likelihood Ratio Test (LR Test) and Wald Test that point to the SEM to be a better model than the SDEM, also because the spatial lags of the variables are not significant.

The results for the Access to Utilities component are in Table 4.15. These results show also that the investments have a negative and significant coefficient, and the spatial lag of the investments have a positive and significant coefficient. The LR test and Wald test also point to the SEM model to be a better fit. This latter result holds for all the components of the UBN. The effects of the arrival variable are not statistically significant in the spatial models. The reasoning behind the lack of relationship is the costs faced to provide access to utilities for new residents.

The regression results for housing conditions show a negative coefficient for the share of urban population and show a positive relationship for the intensity of expulsion (see Table 4.16). The coefficient for the intensity of arrival is statistically insignificant. The percentage of urban population is negatively correlated because when forced migrants moved to the urban areas, they have to share housing with other families while they are getting settled and that process sometimes takes years. The Intensity of Expulsion is positively correlated because after they leave, the number of population living in poor housing conditions decreased more in the town of origin.

The regression results for the education component show that this component is susceptible to the intensity of arrival and expulsion (see Table 4.17), because the pop- 
Juan Tomás Sayago-Gómez Chapter 4. Poverty Changes and Forced Migration 86

Table 4.14: Regression Results for Housing Characteristics Poverty Measured by UBN.

\begin{tabular}{|c|c|c|c|c|}
\hline & (OLS) & (OLS-FE) & $(\mathrm{SEM})$ & (SDEM) \\
\hline Int.Expulsion & $\begin{array}{c}0.079^{* *} \\
(0.033)\end{array}$ & $\begin{array}{c}0.010 \\
(0.031)\end{array}$ & $\begin{array}{c}0.011 \\
(0.027)\end{array}$ & $\begin{array}{l}-0.001 \\
(0.029)\end{array}$ \\
\hline Int. Arrival & $\begin{array}{c}0.107 \\
(0.073)\end{array}$ & $\begin{array}{l}0.138^{* *} \\
(0.067)\end{array}$ & $\begin{array}{l}0.104^{*} \\
(0.055)\end{array}$ & $\begin{array}{l}0.139^{* *} \\
(0.061)\end{array}$ \\
\hline $\log (\mathrm{SGP})$ & $\begin{array}{c}0.004 \\
(0.007)\end{array}$ & $\begin{array}{l}-0.004 \\
(0.007)\end{array}$ & $\begin{array}{c}-0.009^{*} \\
(0.005)\end{array}$ & $\begin{array}{c}-0.009^{*} \\
(0.005)\end{array}$ \\
\hline Pct. Urban & $\begin{array}{c}0.136^{* * *} \\
(0.020)\end{array}$ & $\begin{array}{c}0.086^{* * *} \\
(0.020)\end{array}$ & $\begin{array}{c}0.080^{* * *} \\
(0.017)\end{array}$ & $\begin{array}{c}0.092^{* * *} \\
(0.018)\end{array}$ \\
\hline Density & $\begin{array}{l}-0.00001 \\
(0.00001)\end{array}$ & $\begin{array}{l}-0.00001 \\
(0.00001)\end{array}$ & $\begin{array}{c}0.00000 \\
(0.00001)\end{array}$ & $\begin{array}{l}-0.00000 \\
(0.00001)\end{array}$ \\
\hline lag Int.Expulsion & & & & $\begin{array}{c}0.031 \\
(0.074)\end{array}$ \\
\hline lag Int. Arrival & & & & $\begin{array}{c}0.253 \\
(0.161)\end{array}$ \\
\hline lag Log(SGP) & & & & $\begin{array}{c}0.001 \\
(0.004)\end{array}$ \\
\hline lag Pct. Urban & & & & $\begin{array}{c}0.064 \\
(0.041)\end{array}$ \\
\hline lag Density & & & & $\begin{array}{l}-0.00001 \\
(0.00002)\end{array}$ \\
\hline Constant & $\begin{array}{c}-0.130 \\
(0.108)\end{array}$ & & $\begin{array}{c}0.105 \\
(0.088)\end{array}$ & $\begin{array}{c}0.053 \\
(0.112)\end{array}$ \\
\hline$\lambda$ & & & $\begin{array}{c}0.725^{* * *} \\
(0.026)\end{array}$ & $\begin{array}{c}0.713^{* * *} \\
(0.026)\end{array}$ \\
\hline Observations & 980 & 980 & 980 & 980 \\
\hline $\mathrm{R}^{2}$ & 0.085 & 0.293 & & \\
\hline Adjusted $\mathrm{R}^{2}$ & 0.081 & 0.268 & & \\
\hline Log Likelihood & & & 903.735 & 909.692 \\
\hline$\sigma^{2}$ & & & 0.008 & 0.008 \\
\hline Akaike Inf. Crit. & $0121(d f=974)$ & $0.108(\mathrm{df}=945)$ & $-1,791.469$ & $-1,793.383$ \\
\hline Wald Test $(\mathrm{df}=1)$ & & & $736.732^{* * *}$ & $677.787^{* * *}$ \\
\hline LR Test $(\mathrm{df}=1)$ & & & $450.335^{* * *}$ & $430.342^{* * *}$ \\
\hline
\end{tabular}


Juan Tomás Sayago-Gómez Chapter 4. Poverty Changes and Forced Migration 87

Table 4.15: Regression Results for Access to Utilities Poverty Measured by UBN.

\begin{tabular}{|c|c|c|c|c|}
\hline & $(\mathrm{OLS})$ & (OLS-FE) & $(\mathrm{SEM})$ & (SDEM) \\
\hline Int.Expulsion & $\begin{array}{l}-0.037 \\
(0.033)\end{array}$ & $\begin{array}{c}-0.064^{*} \\
(0.034)\end{array}$ & $\begin{array}{l}-0.037 \\
(0.033)\end{array}$ & $\begin{array}{l}-0.052 \\
(0.035)\end{array}$ \\
\hline Int. Arrival & $\begin{array}{l}0.121^{*} \\
(0.072)\end{array}$ & $\begin{array}{l}0.171^{* *} \\
(0.071)\end{array}$ & $\begin{array}{c}0.100 \\
(0.070)\end{array}$ & $\begin{array}{c}0.100 \\
(0.071)\end{array}$ \\
\hline $\log ($ SGP $)$ & $\begin{array}{l}-0.010 \\
(0.007)\end{array}$ & $\begin{array}{c}-0.014^{* *} \\
(0.007)\end{array}$ & $\begin{array}{c}-0.017^{* *} \\
(0.007)\end{array}$ & $\begin{array}{c}-0.019^{* * *} \\
(0.007)\end{array}$ \\
\hline Pct. Urban & $\begin{array}{c}-0.038^{*} \\
(0.020)\end{array}$ & $\begin{array}{c}-0.043^{* *} \\
(0.022)\end{array}$ & $\begin{array}{l}-0.021 \\
(0.021)\end{array}$ & $\begin{array}{l}-0.013 \\
(0.021)\end{array}$ \\
\hline Density & $\begin{array}{l}-0.00000 \\
(0.00001)\end{array}$ & $\begin{array}{c}0.00000 \\
(0.00001)\end{array}$ & $\begin{array}{c}0.00000 \\
(0.00001)\end{array}$ & $\begin{array}{c}0.00001 \\
(0.00001)\end{array}$ \\
\hline lag Int.Expulsion & & & & $\begin{array}{l}-0.039 \\
(0.077)\end{array}$ \\
\hline lag Int. Arrival & & & & $\begin{array}{c}0.193 \\
(0.167)\end{array}$ \\
\hline lag Log(SGP) & & & & $\begin{array}{l}0.008^{*} \\
(0.005)\end{array}$ \\
\hline lag Pct Urban & & & & $\begin{array}{l}-0.062 \\
(0.038)\end{array}$ \\
\hline lag Density & & & & $\begin{array}{l}-0.00001 \\
(0.00002)\end{array}$ \\
\hline$\lambda$ & & & $\begin{array}{c}0.364^{* * *} \\
(0.043)\end{array}$ & $\begin{array}{c}0.361^{* * *} \\
(0.043)\end{array}$ \\
\hline Constant & $\begin{array}{l}0.243^{* *} \\
(0.107) \\
\end{array}$ & & $\begin{array}{c}0.349^{* * *} \\
(0.109)\end{array}$ & $\begin{array}{l}0.263^{* *} \\
(0.131)\end{array}$ \\
\hline Observations & 980 & 980 & 980 & 980 \\
\hline $\mathrm{R}^{2}$ & 0.015 & 0.117 & & \\
\hline Adjusted $\mathrm{R}^{2}$ & 0.010 & 0.085 & & \\
\hline Log Likelihood & & & 717.798 & 721.046 \\
\hline$\sigma^{2}$ & & & 0.013 & 0.013 \\
\hline $\begin{array}{l}\text { Akaike Inf. Crit. } \\
\text { Residual Std. Error }\end{array}$ & $0.121(\mathrm{df}=974)$ & $0.116(\mathrm{df}=945)$ & $-1,419.597$ & $-1,416.093$ \\
\hline Wald Test $(\mathrm{df}=1)$ & & & $73.109^{* * *}$ & $71.689^{* * *}$ \\
\hline LR Test $(\mathrm{df}=1)$ & & & $67.216^{* * *}$ & $66.720^{* * *}$ \\
\hline
\end{tabular}


Juan Tomás Sayago-Gómez Chapter 4. Poverty Changes and Forced Migration 88

Table 4.16: Regression Results for Housing Conditions Poverty Measured by UBN.

\begin{tabular}{|c|c|c|c|c|}
\hline & (OLS) & (OLS-FE) & $(\mathrm{SEM})$ & (SDEM) \\
\hline Int.Expulsion & $\begin{array}{l}0.041^{* *} \\
(0.020)\end{array}$ & $\begin{array}{c}0.056^{* * *} \\
(0.019)\end{array}$ & $\begin{array}{c}0.036^{*} \\
(0.019)\end{array}$ & $\begin{array}{c}0.029 \\
(0.020)\end{array}$ \\
\hline Int. Arrival & $\begin{array}{l}-0.021 \\
(0.044)\end{array}$ & $\begin{array}{l}-0.008 \\
(0.040)\end{array}$ & $\begin{array}{l}-0.036 \\
(0.040)\end{array}$ & $\begin{array}{l}-0.044 \\
(0.042)\end{array}$ \\
\hline $\log (\mathrm{SGP})$ & $\begin{array}{c}-0.0003 \\
(0.004)\end{array}$ & $\begin{array}{l}-0.003 \\
(0.004)\end{array}$ & $\begin{array}{c}0.001 \\
(0.004)\end{array}$ & $\begin{array}{l}0.0005 \\
(0.004)\end{array}$ \\
\hline Pct Urban & $\begin{array}{c}-0.055^{* * *} \\
(0.012)\end{array}$ & $\begin{array}{c}-0.021^{*} \\
(0.012)\end{array}$ & $\begin{array}{c}-0.035^{* * *} \\
(0.012)\end{array}$ & $\begin{array}{c}-0.036^{* * *} \\
(0.012)\end{array}$ \\
\hline Density & $\begin{array}{c}0.00001 \\
(0.00001)\end{array}$ & $\begin{array}{c}0.00000 \\
(0.00001)\end{array}$ & $\begin{array}{c}0.00000 \\
(0.00001)\end{array}$ & $\begin{array}{c}0.00000 \\
(0.00001)\end{array}$ \\
\hline lag Int.Expulsion & & & & $\begin{array}{c}0.032 \\
(0.048)\end{array}$ \\
\hline lag Int. Arrival & & & & $\begin{array}{c}0.054 \\
(0.103)\end{array}$ \\
\hline lag $\log (\mathrm{SGP})$ & & & & $\begin{array}{l}0.005^{*} \\
(0.003)\end{array}$ \\
\hline lag Pct Urban & & & & $\begin{array}{c}-0.076^{* * *} \\
(0.024)\end{array}$ \\
\hline lag Density & & & & $\begin{array}{c}0.00001 \\
(0.00001)\end{array}$ \\
\hline Constant & $\begin{array}{c}0.078 \\
(0.066)\end{array}$ & & $\begin{array}{c}0.043 \\
(0.064)\end{array}$ & $\begin{array}{c}0.006 \\
(0.078)\end{array}$ \\
\hline$\lambda$ & & & $\begin{array}{c}0.521^{* * *} \\
(0.037)\end{array}$ & $\begin{array}{c}0.510^{* * *} \\
(0.037)\end{array}$ \\
\hline Observations & 980 & 980 & 980 & 980 \\
\hline $\mathrm{R}^{2}$ & 0.035 & 0.272 & & \\
\hline Adjusted $\mathrm{R}^{2}$ & 0.030 & 0.245 & & \\
\hline Log Likelihood & & & $1,246.796$ & $1,253.395$ \\
\hline$\sigma^{2}$ & & & 0.004 & 0.004 \\
\hline Akaike Inf. Crit. & $0.074(d f=974)$ & $0066(\mathrm{df}=945)$ & $-2,477.591$ & $-2,480.790$ \\
\hline Wald Test $(\mathrm{df}=1)$ & & & $202.203^{* * *}$ & $188.540^{* * *}$ \\
\hline LR Test $(\mathrm{df}=1)$ & & & $174.375^{* * *}$ & $166.780^{* * *}$ \\
\hline
\end{tabular}


ulation that was forced out usually are located in rural areas where access to school is inadequate. They gain access to public schools in their new place of residence and the kids' attendance to school is a requirement to receive the economic benefits from a program of conditional cash transfers "Familias en Accion". The results also show a negative significant relationship for the percentage of urban population. It is negatively correlated because the larger cities have already achieved low levels of poverty in this component. The spatial error coefficient is positive and significant, due to the missing information related to the presence of armed groups and other conflict related components as well as the institutional strength of governments in municipalities.

The regression results for the Economic Capacity component are on Table 4.18. They highlight the effect of the poverty change associated with the displacement variable for arrival. This result is explained by the move of a farmer from agricultural production, where part of the income was paid in food and crops used for self consumption, to a different condition where income is received in money. Additionally, the economic conditions in these municipalities are rustic and families are larger, this issue affects the poverty measure with respect to the economic capacity of families in rural areas. When families migrate, the parents usually move with the younger children, because the older kids choose not to migrate with the family or to move to other locations. There is a negative relationship with total investment by the municipalities. This could be explained by the low level of improvement in larger cities that invest more to maintain their current infrastructure.

The application of the analysis to the changes in poverty measured by Multidimensional Poverty Index (MPI) show that forced displacement does not reduce poverty in Colombian municipalities. Furthermore the negative coefficient associated with expulsion reflects that displacement affects the measure of poverty negatively, it increase poverty since positive values of our dependent variable mean poverty decreases. The positive coefficient associated with the arrival of displaced population is not significant. 
Table 4.17: Regression Results for the Access to Education Poverty Measured by UBN.

\begin{tabular}{|c|c|c|c|c|}
\hline & $(\mathrm{OLS})$ & (OLS-FE) & $(\mathrm{SEM})$ & (SDEM) \\
\hline Int.Expulsion & $\begin{array}{c}0.055^{* * *} \\
(0.014)\end{array}$ & $\begin{array}{c}0.015 \\
(0.013)\end{array}$ & $\begin{array}{c}0.034^{* * *} \\
(0.013)\end{array}$ & $\begin{array}{l}0.026^{*} \\
(0.013)\end{array}$ \\
\hline Int. Arrival & $\begin{array}{c}0.052^{*} \\
(0.030)\end{array}$ & $\begin{array}{c}0.077^{* * *} \\
(0.028)\end{array}$ & $\begin{array}{l}0.046^{*} \\
(0.026)\end{array}$ & $\begin{array}{l}0.052^{*} \\
(0.028)\end{array}$ \\
\hline $\log (\mathrm{SGP})$ & $\begin{array}{l}0.0002 \\
(0.003)\end{array}$ & $\begin{array}{l}-0.001 \\
(0.003)\end{array}$ & $\begin{array}{l}-0.003 \\
(0.003)\end{array}$ & $\begin{array}{l}-0.004 \\
(0.003)\end{array}$ \\
\hline Pct.Urban & $\begin{array}{c}-0.076^{* * *} \\
(0.008)\end{array}$ & $\begin{array}{c}-0.088^{* * *} \\
(0.008)\end{array}$ & $\begin{array}{c}-0.066^{* * *} \\
(0.008)\end{array}$ & $\begin{array}{c}-0.068^{* * *} \\
(0.008)\end{array}$ \\
\hline Density & $\begin{array}{c}-0.00001^{*} \\
(0.00000)\end{array}$ & $\begin{array}{c}-0.00001^{*} \\
(0.00000)\end{array}$ & $\begin{array}{l}-0.00000 \\
(0.00000)\end{array}$ & $\begin{array}{l}-0.00000 \\
(0.00000)\end{array}$ \\
\hline lag Int.Expulsion & & & & $\begin{array}{l}-0.003 \\
(0.032)\end{array}$ \\
\hline lag Int. Arrival & & & & $\begin{array}{c}0.104 \\
(0.070)\end{array}$ \\
\hline lag $\log (\mathrm{SGP})$ & & & & $\begin{array}{l}0.004^{* *} \\
(0.002)\end{array}$ \\
\hline lag Pct. Urban & & & & $\begin{array}{c}-0.049^{* * *} \\
(0.017)\end{array}$ \\
\hline lag Density & & & & $\begin{array}{c}0.000 \\
(0.00001)\end{array}$ \\
\hline Constant & $\begin{array}{c}0.100^{* *} \\
(0.044)\end{array}$ & & $\begin{array}{c}0.160^{* * *} \\
(0.041)\end{array}$ & $\begin{array}{l}0.112^{* *} \\
(0.051)\end{array}$ \\
\hline$\lambda$ & & & $\begin{array}{c}0.606^{* * *} \\
(0.033)\end{array}$ & $\begin{array}{c}0.604^{* * *} \\
(0.033)\end{array}$ \\
\hline Observations & 980 & 980 & 980 & 980 \\
\hline $\mathrm{R}^{2}$ & 0.176 & 0.361 & & \\
\hline Adjusted $\mathrm{R}^{2}$ & 0.172 & 0.338 & & \\
\hline Log Likelihood & & & $1,669.638$ & $1,677.460$ \\
\hline$\sigma^{2}$ & & & 0.002 & 0.002 \\
\hline Akaike Inf. Crit. & & & $-3,323.275$ & $-3,328.920$ \\
\hline Residual Std. Error & $0.050(\mathrm{df}=974)$ & $0.045(\mathrm{df}=945)$ & & \\
\hline Wald Test $(\mathrm{df}=1)$ & & & $337.240^{* * *}$ & $334.554^{* * *}$ \\
\hline LR Test $(\mathrm{df}=1)$ & & & $251.047^{* * *}$ & $242.774^{* * *}$ \\
\hline
\end{tabular}


Juan Tomás Sayago-Gómez Chapter 4. Poverty Changes and Forced Migration 91

Table 4.18: Regression Results for the Economic Capacity Poverty Measured by UBN.

\begin{tabular}{|c|c|c|c|c|}
\hline & (OLS) & (OLS-FE) & $(\mathrm{SEM})$ & (SDEM) \\
\hline Int.Expulsion & $\begin{array}{c}0.001 \\
(0.015)\end{array}$ & $\begin{array}{c}0.001 \\
(0.015)\end{array}$ & $\begin{array}{c}0.002 \\
(0.015)\end{array}$ & $\begin{array}{l}-0.001 \\
(0.015)\end{array}$ \\
\hline Int. Arrival & $\begin{array}{c}0.095^{* * *} \\
(0.033)\end{array}$ & $\begin{array}{c}0.096^{* * *} \\
(0.031)\end{array}$ & $\begin{array}{c}0.082^{* * *} \\
(0.031)\end{array}$ & $\begin{array}{c}0.082^{* * *} \\
(0.032)\end{array}$ \\
\hline $\log (\mathrm{SGP})$ & $\begin{array}{c}-0.012^{* * *} \\
(0.003)\end{array}$ & $\begin{array}{c}-0.006^{*} \\
(0.003)\end{array}$ & $\begin{array}{c}-0.008^{* *} \\
(0.003)\end{array}$ & $\begin{array}{c}-0.008^{* * *} \\
(0.003)\end{array}$ \\
\hline Pct.Urban & $\begin{array}{l}-0.001 \\
(0.009)\end{array}$ & $\begin{array}{c}0.026^{* * *} \\
(0.009)\end{array}$ & $\begin{array}{c}0.013 \\
(0.009)\end{array}$ & $\begin{array}{c}0.013 \\
(0.009)\end{array}$ \\
\hline Density & $\begin{array}{c}0.00001^{*} \\
(0.00000)\end{array}$ & $\begin{array}{c}0.00000 \\
(0.00000)\end{array}$ & $\begin{array}{c}0.00000 \\
(0.00000)\end{array}$ & $\begin{array}{c}0.00000 \\
(0.00000)\end{array}$ \\
\hline lag Int.Expulsion & & & & $\begin{array}{l}-0.017 \\
(0.035)\end{array}$ \\
\hline lag Int. Arrival & & & & $\begin{array}{c}0.079 \\
(0.076)\end{array}$ \\
\hline lag Log(SGP) & & & & $\begin{array}{c}0.001 \\
(0.002)\end{array}$ \\
\hline lag Pct. Urban & & & & $\begin{array}{c}-0.068^{* * *} \\
(0.018)\end{array}$ \\
\hline lag Density & & & & $\begin{array}{c}0.00002^{*} \\
(0.00001)\end{array}$ \\
\hline Constant & $\begin{array}{c}0.215^{* * *} \\
(0.049)\end{array}$ & & $\begin{array}{c}0.135^{* * *} \\
(0.049)\end{array}$ & $\begin{array}{l}0.150^{* *} \\
(0.059)\end{array}$ \\
\hline$\lambda$ & & & $\begin{array}{c}0.452^{* * *} \\
(0.039)\end{array}$ & $\begin{array}{c}0.427^{* * *} \\
(0.040)\end{array}$ \\
\hline Observations & 980 & 980 & 980 & 980 \\
\hline $\mathrm{R}^{2}$ & 0.033 & 0.218 & & \\
\hline Adjusted $\mathrm{R}^{2}$ & 0.028 & 0.189 & & \\
\hline Log Likelihood & & & $1,508.213$ & $1,515.785$ \\
\hline$\sigma^{2}$ & & & 0.003 & 0.003 \\
\hline Akaike Inf. Crit. & & & $-3,000.427$ & $-3,005.570$ \\
\hline Residual Std. Error & $0.055(\mathrm{df}=974)$ & $0.050(\mathrm{df}=945)$ & & \\
\hline Wald Test $(\mathrm{df}=1)$ & & & $131.778^{* * *}$ & $112.248^{* * *}$ \\
\hline LR Test $(\mathrm{df}=1)$ & & & $108.055^{* * *}$ & $94.197^{* * *}$ \\
\hline
\end{tabular}


Another important result is the positive relationship between the change in MPI and investments, the percentage of urban population, and density of population, because the poverty is easier to decrease in urban areas and by doing higher investments.

A comparison of the analysis between the UBN and MPI show that the change in poverty measured by the UBN are affected by the forced migration and the MPI results are not affected by the displacement in the same way. This migration shows that the the UBN is affected by changes on urbanization and access to basic urban amenities, while the MPI result does not depend solely on urban amenities to reduce poverty. Because MPI of all the components included in the poverty dimensions in their definition of poverty, and each dimension is based on multiple variables, instead of one variable that can be biased.

\subsection{Policy implications and conclusions}

Forced displacement in Colombia has transformed the demographic composition of the Colombian municipalities. This transformation created a tradeoff for migrants who left all or most of their belongings, but moved to urban areas where they would gain access to the basic urban amenities, such as public utilities, education, and public health services. However, this forced migration also affected the result of the measurement of poverty in Colombian municipalities. The displaced population that was qualified as poor was forced to leave and when this population arrived at the new municipality could be considered as non-poor because of urban benefits gained in the new location.

The issue is that poverty measurements can be affected by demographic transformations. This issue arrises due to the simplicity of the poverty measure used. We compared the results between the Unmet Basic Needs and the recently developed Multidimensional Poverty Index to identify possible issues in both and to verify whether 
Table 4.19: Regression Results for the Total Poverty Measured by MPI.

\begin{tabular}{|c|c|c|c|c|}
\hline & $(\mathrm{OLS})$ & (OLS-FE) & $(\mathrm{SEM})$ & $(\mathrm{SDEM})$ \\
\hline Int.Expulsion & $\begin{array}{c}-0.170^{* * *} \\
(0.032)\end{array}$ & $\begin{array}{c}-0.101^{* * *} \\
(0.024)\end{array}$ & $\begin{array}{c}-0.072^{* * *} \\
(0.020)\end{array}$ & $\begin{array}{c}-0.075^{* * *} \\
(0.023)\end{array}$ \\
\hline Int. Arrival & $\begin{array}{c}0.065 \\
(0.069)\end{array}$ & $\begin{array}{c}0.072 \\
(0.050)\end{array}$ & $\begin{array}{c}0.045 \\
(0.041)\end{array}$ & $\begin{array}{c}0.032 \\
(0.048)\end{array}$ \\
\hline $\log (\mathrm{SGP})$ & $\begin{array}{c}-0.030^{* * *} \\
(0.006)\end{array}$ & $\begin{array}{c}0.001 \\
(0.005)\end{array}$ & $\begin{array}{c}0.021^{* * *} \\
(0.004)\end{array}$ & $\begin{array}{c}0.024^{* * *} \\
(0.004)\end{array}$ \\
\hline Pct Urban & $\begin{array}{c}0.280^{* * *} \\
(0.019)\end{array}$ & $\begin{array}{c}0.317^{* * *} \\
(0.015)\end{array}$ & $\begin{array}{c}0.257^{* * *} \\
(0.013)\end{array}$ & $\begin{array}{c}0.264^{* * *} \\
(0.014)\end{array}$ \\
\hline Density & $\begin{array}{l}0.0001^{* * *} \\
(0.00001)\end{array}$ & $\begin{array}{c}0.00004^{* * *} \\
(0.00001)\end{array}$ & $\begin{array}{c}0.00001 \\
(0.00001)\end{array}$ & $\begin{array}{c}0.00001 \\
(0.00001)\end{array}$ \\
\hline lag. Int.Expulsion & & & & $\begin{array}{l}-0.085 \\
(0.060)\end{array}$ \\
\hline lag. Int. Arrival & & & & $\begin{array}{l}-0.132 \\
(0.130)\end{array}$ \\
\hline lag $\log ($ SGP $)$ & & & & $\begin{array}{l}0.006^{* *} \\
(0.003)\end{array}$ \\
\hline lag Pct Urban & & & & $\begin{array}{c}0.037 \\
(0.035)\end{array}$ \\
\hline lag. Density & & & & $\begin{array}{c}0.00002 \\
(0.00002)\end{array}$ \\
\hline Constant & $\begin{array}{c}0.638^{* * *} \\
(0.103)\end{array}$ & & $\begin{array}{c}-0.232^{* * *} \\
(0.066)\end{array}$ & $\begin{array}{c}-0.382^{* * *} \\
(0.085)\end{array}$ \\
\hline$\lambda$ & & & $\begin{array}{c}0.845^{* * *} \\
(0.019)\end{array}$ & $\begin{array}{c}0.830^{* * *} \\
(0.019)\end{array}$ \\
\hline Observations & 980 & 980 & 980 & 980 \\
\hline $\mathrm{R}^{2}$ & 0.312 & 0.672 & & \\
\hline Adjusted $\mathrm{R}^{2}$ & 0.308 & 0.660 & & \\
\hline Log Likelihood & & & $1,150.441$ & $1,162.034$ \\
\hline$\sigma^{2}$ & & & 0.005 & 0.004 \\
\hline Akaike Inf. Crit. & $0116(d f=974)$ & $0081(\mathrm{df}=945)$ & $-2,284.881$ & $-2,298.067$ \\
\hline Wald Test $(\mathrm{df}=1)$ & & & $1,993.416^{* * *}$ & $1,866.042^{* * *}$ \\
\hline LR Test $(\mathrm{df}=1)$ & & & $855.066^{* * *}$ & $816.951^{* * *}$ \\
\hline
\end{tabular}


both are affected by the displacement of population in Colombia.

The Shift-Share analysis applied to poverty measurements helps assess the composition of improvements and the changes in poverty in Colombian regions. Several conclusions can be drawn by the insights from the composition of improvement in growth rates. First, regions improve some components more than others, but across the country, regions with higher growth are the most populated areas and the areas that have higher growth rates in income. Second, the poorest areas reduced poverty but the growth rates were significantly lower. Third, the oil regions have increased their development but it should be further investigated as to whether the entire department improved or only the oil producing municipalities. Poverty decreased in Colombia (see Table 4.3) but the components improved differently by region. The trend differentials show that a small group of municipalities became poles in development, while others have improved more slowly.

The millennium goal of reducing poverty by half has probably been accomplished, but the equity of this development is not a reality. Part of the result obtained from the bias in the UBN methodology caused by the demographic transformation caused by forced displacement. The change created by forced displacement that caused ruralurban migration of about $10 \%$ of the population also affected the measurement of poverty. This flow of $10 \%$ of the population that moved to live in poorer conditions are being considered as non-poor. It led to a mistaken evaluation of the change experienced. 


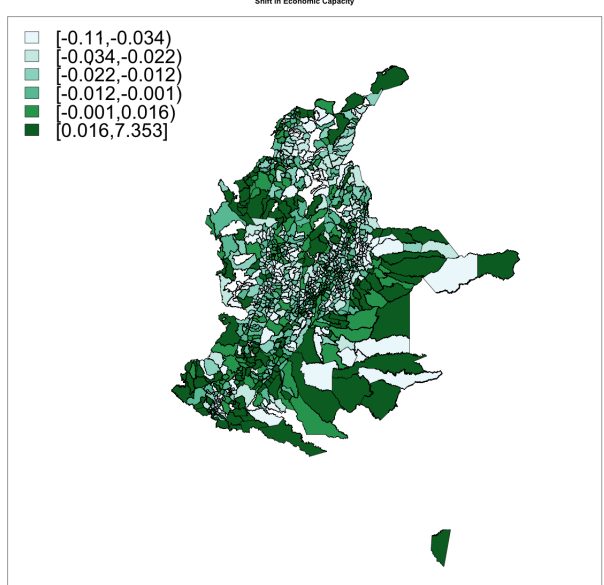

(a) Economic dependence

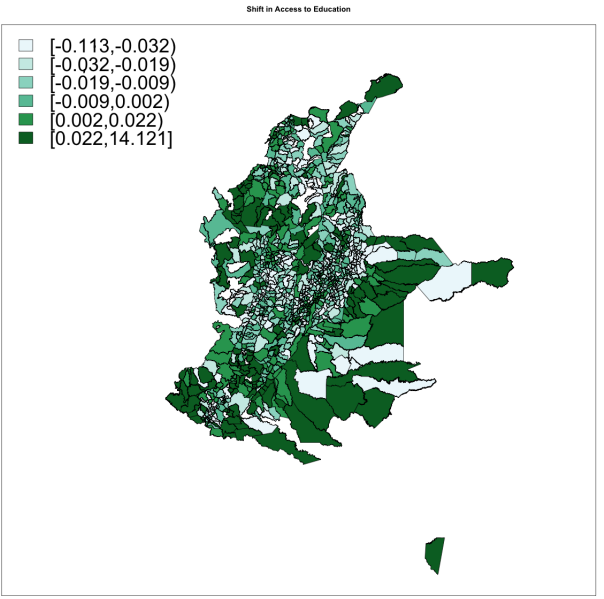

(c) School attendance

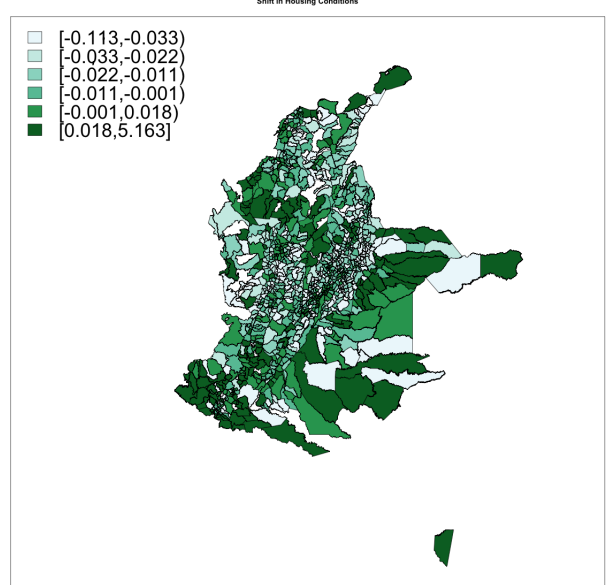

(b) Housing Conditions

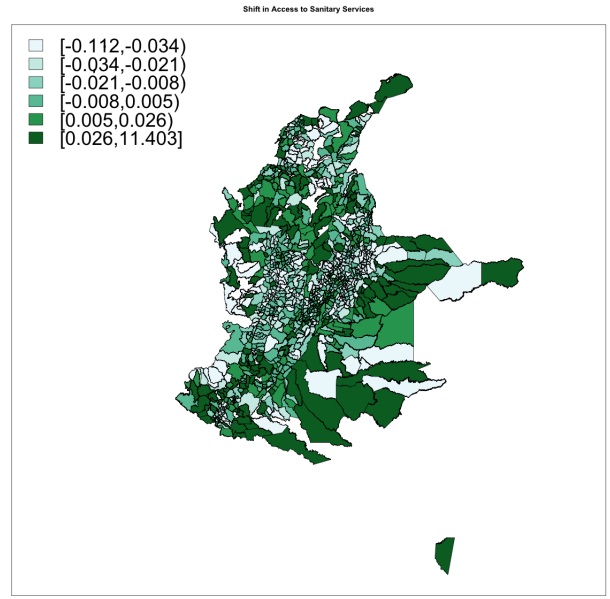

(d) Public services

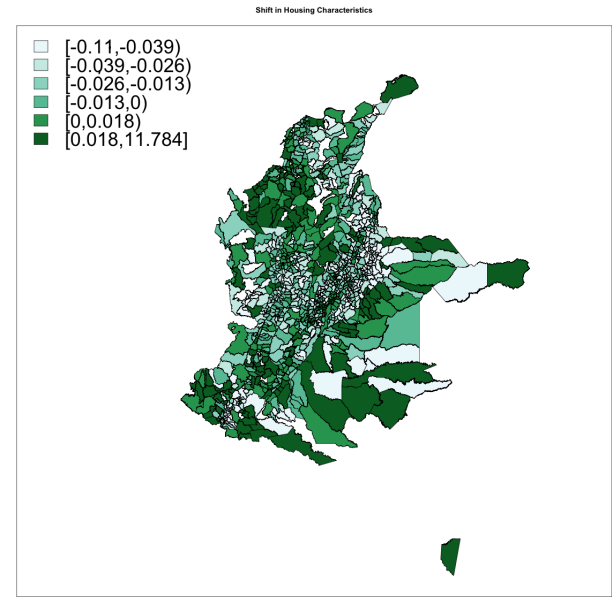

(e) House characteristics

Figure 4.5: Shift in trend growth rate of non-poor population in the Municipalities 


\section{Chapter 5}

\section{Conclusions}

\subsection{Conclusions}

This dissertation explored different elements related to immigration and its consequences on socioeconomic outcomes. The use of econometric techniques to approach these hypotheses provides policymakers with answers regarding the possible outcomes from immigration and further movements. These results are an important extension

of the consequences from migration onto crime, and how the migration affects poverty measurements. Finally the dissertation also extends the current literature on the determinants for location choices of undocumented immigrants in the United States.

Chapter 2 analyzes whether the European Union enlargements in 2004 and 2007 caused increases in crime rates of two very popular European countries for immigrants. Following the approach taken by studies applied to the United States and United Kingdom, I extended the approach considering the issues from estimating instrumental variable data panel models with fixed effects and comparing the outcome with the random effects counterpart. The results from the analysis indicate that the increased in migration from all countries does not affect the total crime rate, violent crime rate, or property crime rate. This result holds for the same types of crime and for immigrants from specific origins such as African, and Latin American. However I find a positive and significant correlation between the share of European immigrants and the property 
crime rates in these regions.

In Chapter 3, I explore the location choice of undocumented immigrants. I estimate a spatial panel model that considers the dynamics of the location of undocumented immigrants by state in the United States. The effect of the economic variables are in the expected directions. However, the spatial model accounts for the spreading effect of undocumented immigrants that also locate in neighboring states in subsequent migrations, as migrants keep moving until they find a place where they can be located. The sanctuary cities provide an environment for immigrants to locate and feel safe. However the existence of the sanctuary city by itself is not the main attraction for the immigrant. Instead, the size of the population in the sanctuary can measure more accurately the attractiveness of the state.

Chapter 4 addresses the effect of forced migration on poverty. Forced migration in Colombia provides a case where migrants have to flee to save their lives. They leave their belongings behind for safety, not because they decided that they were going to look for a better economic condition. This exogeneity provides an interesting case because it transforms the demographic structure of the Colombian population. The analysis reveals that all official measures of poverty by Unsatisfied Basic Needs were affected by the displacement. Additionally I find that the different components in the UBN measure showed decrease in poverty, because the destination has controlled the component and the origin decreases the population that suffers the problem. Testing the issue with a newly develop measure of poverty, I find that the new measurement shows that the change in poverty is not correlated to the forced displacement and confirming the deficiencies of the official measures. 


\section{$5.2 \quad$ Future research}

The future research on migration issues should consider the actual changes in the countries analyzed for this dissertation. First the Brexit and changes from United Kingdom leaving the European Union will create a new diaspora of migrants returning to Europe and finding a way to relocate. This movement will create changes in the labor market. These changes will create another increase of immigrants in the European Union countries that will not be prepared to handle these movement of population.

The current migratory policies by the government of Donald Trump is going to create new research ideas because undocumented immigrants are now being subject to a stronger enforcement of controls by the police and other security institutions. Their behavior will probably change and they will probably attempt to remain hidden and not to take part of their usual activities. Additionally the uncertainty of foreign immigrants on the future prospects of a long term migration to United States will push out top researchers and immigrants to other countries where they can feel reassured that they can stay for long term. 


\section{References}

Acosta, P., Calderon, C., Fajnzylber, P., and Lopez, H. (2008). What is the impact of international remittances on poverty and inequality in latin america? World Development, 36(1):89-114.

Adams, R., Lopez-Feldman, A., Mora, J., Taylor, J., DeWind, J., and Holdaway, J. (2008). Remittances, inequality and poverty: Evidence from rural mexico. Migration and development within and across borders: research and policy perspectives on internal and international migration, pages 101-130.

Adams, R. H. and Page, J. (2005). Do international migration and remittances reduce poverty in developing countries? World development, 33(10):1645-1669.

Alkire, S. and Foster, J. (2011a). Counting and multidimensional poverty measurement. Journal of Public Economics, 95(7-8):476-487.

Alkire, S. and Foster, J. (2011b). Understandings and misunderstandings of multidimensional poverty measurement. The Journal of Economic Inequality, 9(2):289-314.

Amuedo-Dorantes, C. and Bansak, C. (2014). Employment Verification Mandates And The Labor Market Outcomes Of Likely Unauthorized And Native Workers. Contemporary Economic Policy, 32(3):671-680.

Amuedo-Dorantes, C. and Pozo, S. (2014). On the Intended and Unintended Consequences of Enhanced U.S. Border and Interior Immigration Enforcement: Evidence From Mexican Deportees. Demography, 51(6):2255-2279.

Amuedo-Dorantes, C. and Sparber, C. (2014). In-state tuition for undocumented immigrants and its impact on college enrollment, tuition costs, student financial aid, and indebtedness. Regional Science and Urban Economics, 49(C):11-24.

Angulo, R., Díaz, Y., and Pardo, R. (2011). Índice de Pobreza Multidimensional para Colombia. Technical Report 009228, DEPARTAMENTO NACIONAL DE PLANEACIN. 
Angulo, R., Díaz, Y., and Pardo, R. (2013). Multidimensional poverty in Colombia, 1997-2010. ISER Working Paper Series 2013-03, Institute for Social and Economic Research.

Angulo, R., Díaz, Y., and Pardo, R. (2016). The Colombian Multidimensional Poverty Index: Measuring Poverty in a Public Policy Context. Social Indicators Research, 127(1):1-38.

Anselin, L., Bera, A. K., Florax, R., and Yoon, M. J. (1996). Simple diagnostic tests for spatial dependence. Regional science and urban economics, 26(1):77-104.

Anselin, L., Gallo, J. L., and Jayet, H. (2008). Spatial panel econometrics. In Mátyás, L. and Sevestre, P., editors, The econometrics of panel data, pages 625-660. Springer.

Arbia, G. (2014). A Primer for Spatial Econometrics: With Applications in R. Palgrave Texts in Econometrics. Palgrave Macmillan UK.

Atuesta, L. H. (2012). Three essays on households' location decisions: analysis of the processes of gentrification and rural-urban migration. $\mathrm{PhD}$ dissertation, University of Illinois at Urbana-Champaign.

Azevedo, J. P., Inchauste, G., Olivieri, S., Saavedra, J., and Winkler, H. (2013a). Is labor income responsible for poverty reduction ? a decomposition approach. Policy Research Working Paper Series 6414, The World Bank.

Azevedo, J. P., Inchauste, G., and Sanfelice, V. (2013b). Decomposing the recent inequality decline in Latin America. Policy Research Working Paper Series 6715, The World Bank.

Baker, S. R. (2015). Effects of Immigrant Legalization on Crime. American Economic Review, 105(5):210-13.

Baltagi, B. (2005). Econometric analysis of panel data. Wiley, 3. ed. edition. 
Baltagi, B. H. (2006). Estimating an economic model of crime using panel data from north carolina. Journal of Applied Econometrics, 21(4):543-547.

Bandyopadhyay, S. and Bandyopadhyay, S. C. (1998). Illegal Immigration: a Supply Side Analysis . Journal of Development Economics , 57(2):343 - 360.

Bandyopadhyay, S. and Pinto, S. M. (2017). Unauthorized Immigration and Fiscal Competition. European Economic Review, 92(C):283-305.

Becker, G. S. (1968). Crime and punishment: An economic approach. Journal of Political Economy, 76:169.

Bell, B., Fasani, F., and Machin, S. (2013). Crime and Immigration: Evidence from Large Immigrant Waves. The Review of Economics and Statistics, 95(4):1278-1290.

Bell, B. and Machin, S. (2013). Immigrant Enclaves And Crime. Journal of Regional Science, 53(1):118-141.

Bianchi, M., Buonanno, P., and Pinotti, P. (2012). Do Immigrants Cause Crime? Journal of the European Economic Association, 10(6):1318-1347.

Bond, E. and Chen, T.-J. (1987). The Welfare Effects of Illegal Immigration. Journal of International Economics, 23(3-4):315-328.

Bonet-Morón, J. (1999). El crecimiento regional en colombia, 1980-1996: una aproximación con el método shift-share. Documentos de trabajo sobre economía regional 002481, Banco de la República.

Borjas, G. J., Grogger, J., and Hanson, G. H. (2006). Immigration and AfricanAmerican Employment Opportunities: The Response of Wages, Employment, and Incarceration to Labor Supply Shocks. NBER Working Papers 12518, National Bureau of Economic Research, Inc.

Brueckner, J. K. and Zenou, Y. (1999). Harris-Todaro Models with a Land Market. Regional Science and Urban Economics, 29(3):317-339. 
Buehn, A. and Eichler, S. (2013). Determinants of Illegal Mexican Immigration into the US Southern Border States. Eastern Economic Journal, 39(4):464-492.

Bureau of Economic Analysis (2017). Regional economic accounts. https://www.bea.gov/.

Butcher, K. F. and Piehl, A. M. (1998). Cross-city Evidence on the Relationship between Immigration and Crime. Journal of Policy Analysis and Management, 17(3):457-493.

Capello, R. (2007). Regional Economics. Routledge advanced texts in economics and finance. Routledge.

Cardenas, M., Eslava, M., and Ramirez, S. (2016). Why internal conflict deteriorates state capacity? Evidence from Colombian municipalities. Defence and Peace Economics, 27(3):353-377.

Cebula, R., Duquette, C., and Mixon, F. (2013). Factors Influencing the State-Level Settlement Pattern of the Undocumented Immigrant Population in the United States. Atlantic Economic Journal, 41(3):203-213.

Cebula, R. and Nair-Reichert, U. (2015). Access to Higher Public Education and Location Choices of Undocumented Migrants: An Exploratory Analysis. International Advances in Economic Research, 21(2):189-199.

Cebula, R. J. (2016a). Give me sanctuary! the impact of personal freedom afforded by sanctuary cities on the 2010 undocumented immigrant settlement pattern within the us, 2sls estimates. Journal of Economics and Finance, 40(4):792-802.

Cebula, R. J. (2016b). Panel Data Analysis of the Impact of Economic Freedom as Well as Economic Conditions, The Quality of Life, and Public Education Spending on U.S. Undocumented Immigrant Settlement Patterns. Quarterly Journal of Econometrics Research, 2(2):28-41. 
Cebula, R. J., Foley, M., and Boylan, R. (2014). The impact of unionization and other factors on undocumented immigrant settlement patterns in the us. Applied Economics Letters, 21(4):272-275.

Chiswick, B. R. (1988). Illegal immigration and immigration control. Journal of Economic Perspectives, 2(3):101-15.

Cushing, B. (2005a). Specification of Functional Form in Models of Population Migration. Working Papers Working Paper 2005-05, Regional Research Institute, West Virginia University.

Cushing, B. (2005b). The Role of Welfare and Space in the Migration of the Poor. Working Papers Working Paper 2005-08, Regional Research Institute, West Virginia University.

Cushing, B. and Poot, J. (2003). Crossing boundaries and borders: Regional science advances in migration modelling. Papers in Regional Science, 83(1):317-338.

Cushing, B. J. (1986). Accounting for Spatial Relationships in Models of Interstate Population Migration. The Annals of Regional Science, 20(2):66-73.

D'Amuri, F. and Peri, G. (2014). Immigration, Jobs, And Employment Protection: Evidence From Europe Before And During The Great Recession. Journal of the European Economic Association, 12(2):432-464.

Datt, G. and Ravallion, M. (1992). Growth and redistribution components of changes in poverty measures : A decomposition with applications to Brazil and India in the 1980s. Journal of Development Economics, 38(2):275-295.

de Sousa, F. L. (2014). Does Crime Affect Migration Flows? Papers in Regional Science, 93:S99-S111.

Delbecq, B. A. and Waldorf, B. S. (2010). Going West In The European Union:Migration And Eu Enlargement. Working Papers 10-4, Purdue University, College of Agriculture, Department of Agricultural Economics. 
Djajic, S. (1987). Illegal aliens, unemployment and immigration policy. Journal of Development Economics, 25(1):235-249.

Djajic, S. and Michael, M. S. (2014). Controlling illegal immigration: On the scope for cooperation with a transit country. Review of International Economics, 22(4):808824.

Dorigo, G. and Tobler, W. (1983). Push-Pull Migration Laws. Annals of the Association of American Geographers, 73(1):1-17.

Eichler, S. (2010). How many illegal Mexican immigrants enter the United States, where, and why? . Technical report, Forum for Research in Empirical International Trade.

Elhorst, J. P. (2010). Applied Spatial Econometrics: Raising the Bar. Spatial Economic Analysis, 5(1):9-28.

Elhorst, J. P. (2014). Spatial Econometrics From Cross-Sectional Data to Spatial Panels. SpringerBriefs in Regional Science. Springer.

Esteban-Marquillas, J. M. (1972). A reinterpretation of shift-share analysis. Regional and Urban Economics, 2(3):249-255.

Ethier, W. J. (1986). Illegal Immigration: The Host-Country Problem. The American Economic Review, 76(1):56-71.

European Union (2013). EU member countries ' http://europa.eu/about-eu/ countries/member-countries/. Accessed: 2016-01-23.

Feres, J. C. and Mancero, X. (2001). El método de las necesidades básicas insatisfechas (nbi) y sus aplicaciones en américa latina. Technical report, CEPAL.

Franklin, R. and Plane, D. A. (2004). A shift-share method for the analysis of regional fertility change: An application to the decline in childbearing in italy, 1952-1991. Geographical Analysis, 36(1):1-20. 
Franklin, R. S. (2012). An examination of the geography of population composition and change in the united states, 2000-2010: Insights from geographical indices and a shift-share analysis. Population, Space and Place, pages n/a-n/a.

Gaytn-Fregoso, H. and Lahiri, S. (2000). Foreign aid and illegal immigration. Journal of Development Economics, 63(2):515 - 527 .

Giulietti, C., Guzi, M., Kahanec, M., and Zimmermann, K. F. (2013). Unemployment benefits and immigration: evidence from the EU. International Journal of Manpower, $34(1): 24-38$.

Greenwood, M. J. (1975). Research on internal migration in the united states: a survey. Journal of Economic Literature, pages 397-433.

Greenwood, M. J. (1985). Human Migration: Theory, Models, and Empirical Studies. Journal of regional Science, 25(4):521-544.

Greenwood, M. J. (1993). Internal migration in developed countries. In Rosenzweig, M. R. and Stark, O., editors, Handbook of Population and Family Economics, volume 1 of Handbook of Population and Family Economics, chapter 12, pages 647-720. Elsevier.

Greenwood, M. J. and Hunt, G. L. (2003). The early history of migration research. International Regional Science Review, 26(1):3-37.

Greenwood, M. J., Hunt, G. L., Rickman, D. S., and Treyz, G. I. (1991). Migration, Regional Equilibrium, and the Estimation of Compensating Differentials. The American Economic Review, 81(5):1382-1390.

Gupta, S., Pattillo, C. A., and Wagh, S. (2009). Effect of remittances on poverty and financial development in sub-saharan africa. World development, 37(1):104-115.

Hanson, G. H. (2006). Illegal migration from mexico to the united states. Journal of Economic Literature, 44(4):869-924. 
Hanson, G. H. (2009). The economics and policy of illegal immigration in the united states. Technical report, Migration Policy Institute.

Hanson, G. H. and McIntosh, C. (2007). The great mexican emigration. NBER Working Papers 13675, National Bureau of Economic Research, Inc.

Hanson, G. H. and Spilimbergo, A. (1999). Illegal immigration, border enforcement, and relative wages: Evidence from apprehensions at the u.s.-mexico border. American Economic Review, 89(5):1337-1357.

Hanson, G. H. and Spilimbergo, A. (2001). Political economy, sectoral shocks, and border enforcement. Canadian Journal of Economics, 34(3):612-638.

Harris, J. R. and Todaro, M. P. (1970). Migration, unemployment and development: A two-sector analysis. The American Economic Review, 60(1):pp. 126-142.

Hausman, J. A. (1978). Specification Tests in Econometrics. Econometrica, 46(6):12511271.

Hillman, A. L. and Weiss, A. (1999). A Theory of Permissible Illegal Immigration. European Journal of Political Economy, 15(4):585-604.

Huppi, M. and Ravallion, M. (1991). The sectoral structure of poverty during an adjustment period: Evidence for Indonesia in the mid-1980s. World Development, 19(12):1653-1678.

Ibáñez, A. M. (2008). El desplazamiento forzoso en Colombia: un camino sin retorno hacia la pobreza. Universidad de los Andes - CEDE.

Ibáñez, A. M. and Moya, A. (2010). Do Conflicts Create Poverty Traps? Asset Losses and Recovery for Displaced Households in Colombia. In The Economics of Crime: Lessons for and from Latin America, NBER Chapters, pages 137-172. National Bureau of Economic Research, Inc. 
Jackson, R. W. and Haynes, K. E. (2009). Shift-Share Analysis . In Kitchin, R. and Thrift, N., editors, International Encyclopedia of Human Geography, pages 125 131. Elsevier, Oxford.

Jaitman, L. and Machin, S. (2013). Crime and Immigration: New Evidence from England and Wales. CEP Discussion Papers dp1238, Centre for Economic Performance, LSE.

Kahanec, M., Zimmermann, K. F., Kureková, L. M., and Biavaschi, C. (2013). Report No. 56: Labour Migration from EaP Countries to the EU ? Assessment of Costs and Benefits and Proposals for Better Labour Market Matching. IZA Research Reports 56, Institute for the Study of Labor (IZA).

Le Brun, A. N. (2008). Essays on Immigration and Crime. PhD thesis, University of California, Berkeley.

LeSage, J. (2014). What regional scientists need to know about spatial econometrics. The Review of Regional Studies, 44(1):13-32.

LeSage, J. and Pace, R. (2010). Introduction to Spatial Econometrics. Statistics: A Series of Textbooks and Monographs. Taylor \& Francis.

LeSage, J. P. and Pace, R. K. (2008). Spatial Econometric Modeling Of OriginDestination Flows. Journal of Regional Science, 48(5):941-967.

LeSage, J. P. and Thomas-Agnan, C. (2015). Interpreting Spatial Econometric OriginDestination Flow Models. Journal of Regional Science, 55(2):188-208.

Loveridge, S. and Selting, A. C. (1998). A review and comparison of shift-share identities. International Regional Science Review, 21(1):37-58.

Lowry, I. S. (1966). Migration and metropolitan growth: two analytical models. Chandler Pub. Co. 
Lozano-Gracia, N., Piras, G., nez, A. M. I., and Hewings, G. J. D. (2010). The journey to safety: Conflict-driven migration flows in colombia. International Regional Science Review, 33(2):157-180.

Lucas, R. E. (1993). Internal migration in developing countries. In Rosenzweig, M. R. and Stark, O., editors, Handbook of Population and Family Economics, volume 1 of Handbook of Population and Family Economics, chapter 13, pages 721-798. Elsevier.

Machado, A. (2011). Colombia Rural: Razones para una esperanza . Informe de Desarrollo Humano, PNUD, Colombia. PNUD.

Mastrobuoni, G. and Pinotti, P. (2015). Legal Status and the Criminal Activity of Immigrants. American Economic Journal: Applied Economics, 7(2):175-206.

Moehling, C. and Piehl, A. M. (2007). Immigration and Crime in Early 20th Century America. NBER Working Papers 13576, National Bureau of Economic Research, Inc.

Nair-Reichert, U. (2014). Location Decisions of Undocumented Migrants in the United States. Journal of Regional Analysis and Policy, 44(2):157-165.

Nazara, S. and Hewings, G. J. (2004). Spatial structure and taxonomy of decomposition in shift-share analysis. Growth and Change, 35(4):476-490.

Nunziata, L. (2015). Immigration and Crime: Evidence from Victimization data. Journal of Population Economics, 28(3):697-736.

Ohio Jobs \& Justice PAC (2017). The original list of sanctuary cities. http://www.ojjpac.org/sanctuary.asp.

Passel, J. (2007). Unauthorized migrants in the united states: Estimates, methods, and characteristics. OECD Social, Employment and Migration Working Papers 57, OECD Publishing. 
Passel, J. S. and Cohn, D. (2011). Unauthorized immigrant population: National and state trends, 2010. Technical report, Pew Hispanic Center.

Pérez Pérez, J. E., Rodriguez Castelan, C., Trujillo, J. D., and Valderrama, D. (2015). Unpacking the MPI : a decomposition approach of changes in multidimensional poverty headcounts. Policy Research Working Paper Series 7514, The World Bank.

Plane, D. A. (1987). The geographic components of change in a migration system. Geographical Analysis, 19(4):283-299.

Plane, D. A. (1992). Age-composition change and the geographical dynamics of interregional migration in the u.s. Annals of the Association of American Geographers, 82(1):pp. 64-85.

Pradhan, G., Upadhyay, M., and Upadhyaya, K. (2008). Remittances and economic growth in developing countries. The European journal of development research, 20(3):497-506.

Ramírez, J. M., Bedoya, J. G., and Díaz, Y. (2016). Geografa econmica, descentralizacin y pobreza multidimensional en Colombia. CUADERNOS DE FEDESARROLLO 014443, FEDESARROLLO.

Ravenstein, E. G. (1885). The laws of migration. Journal of the Statistical Society of London, 48(2):pp. 167-235.

Ravenstein, E. G. (1889). The laws of migration. Journal of the Royal Statistical Society, 52(2):pp. 241-305.

Saiz, A. (2007). Immigration and Housing rents in American Cities. Journal of Urban Economics, 61(2):345-371.

Sayago-Gómez, J. T. (2012a). Desplazamiento forzoso en colombia: expulsión y movilidad, dos dinámicas que interactúan. Magister en Ciencias Económicas. 
Sayago-Gómez, J. T. (2012b). Rurality in colombia. Technical report, West Virginia University.

Selting, A. C., Loveridge, S., et al. (1992). A summary of the literature on shiftshare analysis. Technical report, University of Minnesota, Department of Applied Economics.

Sjaastad, L. A. (1962). The costs and returns of human migration. Journal of Political Economy, 70(5):pp. 80-93.

Spenkuch, J. (2014). Understanding the Impact of Immigration on Crime. American Law and Economics Review, 16(1):177-219.

Stark, O. and Lucas, R. E. B. (1988). Migration, Remittances, and the Family. Economic Development and Cultural Change, 36(3):465-481.

Stark, O., Taylor, J. E., and Yitzhaki, S. (1986). Remittances and inequality. The economic journal, 96(383):722-740.

Stark, O., Taylor, J. E., and Yitzhaki, S. (1988). Migration, remittances and inequality : A sensitivity analysis using the extended Gini index. Journal of Development Economics, 28(3):309-322.

Stevens, B. H. and Moore, C. L. (1980). A critical review of the literature on shift-share as a forecasting technique. Journal of Regional Science, 20(4):419-437.

UN Committee on Economic, S. and (CESCR), C. R. (2009). Implementation of the International Covenant on Economic, Social and Cultural Rights : combined initial and 2nd and 3rd periodic reports under articles 16 and 17 of the Covenant : Colombia. http://www.refworld.org/docid/4a27813f4.html.

Warren, R. and Warren, J. R. (2013). Unauthorized immigration to the united states: Annual estimates and components of change, by state, 1990 to 2010. International Migration Review, 47(2):296-329. 
Woodland, A. D. and Yoshida, C. (2006). Risk Preference, Immigration Policy and Illegal Immigration . Journal of Development Economics , 81(2):500 - 513. 